\title{
Submembrane cytoskeleton-regulated assembly and functional activity of gap junctions
}

\author{
Dissertation \\ zur Erlangung des Doktorgrades \\ der Mathematisch-Naturwissenschaftlichen Fakultäten \\ der Georg-August-Universität zu Göttingen
}

vorgelegt von

Eugenia Butkevich

aus Omsk, Rußland

Göttingen, 2004 


\section{D7}

Referent: Prof. Dr. F.-W. Schürmann.

Korreferent: Prof. Dr. R. Jahn

Tag der mündlichen Prüfung: 29.06.2004 


\section{Abbreviations}

AD

ATP

BSA

cAMP

$\mathrm{Cx}$

CT

CY-3

DMEM

DMSO

E.coli

EDTA

EGTA

ER

FCS

FRET

GJ

GST

GSSG

IPTG

MALDI-Q-TOF MS

PAGE

PM

PVDV

RT

SDS

si-RNA

TEMED

wt
Alzheimer's disease adenosine triphosphate

bovin serum albumine

cyclic adenosine monophosphate

connexin

$\mathrm{COOH}$-terminus

indigocarbocyanine

Dulbecco's minimal essential medium

dimetyl sulfonyl fluorid

Escherichia coli

ethylenediaminetetraacetic acid

ethylene glycol-bis(ß-amino-ethyl ether)

endoplasmic reticulum

foetal calf serum

fluorescence resonance energy transfer

gap junction

glutathione S-transferase

glutathione (oxidised)

isopropyl-thio- $\beta$-D-galactoside

matrix assisted laser desorption/ionisation

quadripole time of flight mass spectrometry

polyacrylamide gel electrophoresis

plasma membrane

polyvinylidene difluoride

room temperature

sodium dodecyl sulfate

small interferens RNA

1,2-Bis-(dimethylamino)-ethane

wild type 


\section{Contents}

1. Introduction 1

1.1 Preface 1

1.2 The connexins family 1

1.3 Transmembrane topology of connexins 3

1.4 Intracellular trafficking of connexins 4

1.5 Connexin phosphorylation 5

1.6 Connexin degradation 5

1.7 Interaction between connexins and protein partners 6

1.7.1 Calmodulin directly gates gap junction channels 6

1.7.2.Assosiation of connexins with Zonula occludens-1 6

1.7.3 Cadherins facilitate the formation of gap junctions $\quad 7$

1.7.4 Protein kinases which phosphorilate connexin43 8

1.7.5 Connexins and cytoskeletal proteins 9

1.7.5.1 Tubulin 9

1.7.5.2 Actin 9

$\begin{array}{ll}1.8 \text { Connexin and signal transduction } & 10\end{array}$

$\begin{array}{ll}1.9 \text { Dysfunctions of connexins and human diseases } & 10\end{array}$

2. Aim of this work 13

$\begin{array}{ll}\text { 3. Materials } & 14\end{array}$

4. Methods 17

4.1 Construction of pGST-CT-Cx43 17

4.2 Expression and purification of GST-CT-Cx43 protein 18

4.3 Preparation of brain fractions for pull down assay 19

4.4 Pull down assay using Glutathione Sepharose fusion protein 19

$\begin{array}{ll}4.5 \mathrm{PCR} & 20\end{array}$

4.6 DNA-gel electrophoresis 21

4.7 Purification of PCR products $\quad 21$

4.8 DNA sequence analysis $\quad 21$

4.9 Estimation of DNA purity and concentration 22

4.10 Restriction enzyme digestion $\quad 22$

4.11 Ligation $\quad 22$

4.12 Preparation of competent E. coli for heat shock transformation 22 
4.13 Preparation of electro-competent E.coli cells

4.14 Transformation of E.coli by electroporation

4.15 Precepitation of DNA using plasmid mini and maxi-preps

4.16 Antibodies

4.16.1 Covalent linking of peptides to carrier protein using the bifunctional reagent sulfo- SMCC

4.16.2 Rabbit immunization

4.16.3 Purification of antibodies

4.17 Determination of protein concentration

4.18 Subcellular fractionation of cultured cells

4.19 Immunoprecipitation

4.20 Denaturing polyacrilamide gel electrophoresis (SDS-PAGE)

4.21 Staining of proteins at the SDS-PAGE

4.22 Immunoblotting

4.22.1 Western blotting onto nitrocellulose membranes

4.22.2 Western blotting onto PVDF membranes

4.22.3 Immunostaining of Western blots

4.22.4 Chemiluminescence

4.23 Protein sequencing

4.24 Mammalian cell culture techniques

4.24.1 Cell culture

4.24. cDNA transfection of cultured cells by electroporation

4.24.3 cDNA transfection using Lipofectamine 2000

4.24.4 si-RNA transfection

4.25 Indirect immunofluorescence

4.26 Fluorescence and immunofluorescence microscopy and image processing

4.27 FRET analysis

4.28 Electron microscopy of ultrathin cryo-sections

4.29 Microinjection

4.30 Electrical coupling analysis using double patch clamp in whole cell configuration 36

5. Results

5.1 Intracellular transport of connexin43

5.2 Involvement of small GTPases in the transport of connexin43

5.3 Pool down assay with GST-CT-Cx43, protein sequencing and identification of 
drebrin as a $\mathrm{Cx} 43$-interacting protein 40

5.4 Colocalization of drebrin and connexin43 at cell-cell contacts

5.5 Drebrin and connexin43 in subcellular fractions and immunoprecipitation using anti-Cx43 antibodies

5.6 Co-expression of fluorescent connexin43 and drebrin fusion proteins in live cells 46

5.7 FRET analyses indicates CFP-drebrin/connexin43-YFP interaction in live cells 46

5.8 Analysis of connexin43-drebrin interaction by si-RNA-induced drebrin depletion 51

5.9 Effect of latrunculin B on a state of drebrin 55

5.10 Functional analyses of connexin43-drebrin interaction 56

5.10.1 Dye transfer analysis 56

5.10.2 Electrical coupling experiments 56

6. Discussion 58

6.1 Involvement of small GTPases in the intracellular trafficking of connexin43 58

6.2 Identification of proteins interacting with connexin43 60

6.3 Interaction between connexin43 and drebrin 61

6.4 Drebrin - connexin43 interaction occurs under the plasma membrane of $\begin{array}{ll}\text { contacting cells } & 62\end{array}$

6.5 Drebrin may facilitate formation of gap junctions by alignment of the plasma membranes of contacting cells

6.6 Interaction between drebrin and connexin at gap junctions is stronger than interaction between drebrin and actin

6.7 Drebrin is required for the functional activity of gap junctions between contacting cells

6.8 Drebrin keeps the phosphorylated forms of connexin43 at the plasma membrane

6.9 Stabilisation of gap junctions under the plasma membrane by drebrin prevents its degradation

6.10 Drebrin may serve to convey signals from the connexin43 to intracellular effectors

6.11 Connexin dysfunction can be responsible for the memory loss at Alzheimer's disease 


\section{Introduction}

\subsection{Preface}

Cells communicate with each other in a variety of ways. One way of communication involves gap junctions, which allow for the intercellular transmission of molecules through specialised channels localised to the plasma membrane domains of cell-cell contact (Kumar and Gilula, 1992).

The existence of gap junctions allows an intercellular exchange of low molecular weight molecules including ions, metabolites, and second messengers like cAMP, calcium, and inositol 1,4,5-trisphosphate, but prevents the movement of molecules larger than $1 \mathrm{kDa}$ such as proteins and nucleic acids. Gap junctions provide a pathway linking the cytoplasm of attached cells and contribute to the integration of metabolic activities by setting up networks of communicative cell assemblies. By electrically coupled neurons, gap junctions allow action potential to spread between cells. Key features of electrical transmission are that it is extremely rapid, it is a high fidelity (signals are transmitted with no distortion), and it works in both directions.

Gap junctions are implicated in diverse biological processes, such as development, cellular metabolism, and cellular growth control. Intercellular communications via gap junctions contribute to metabolic co-operation and synchronisation of cellular physiological activities. Electrical coupling allows the rapid and synchronous propagation of action potential in excitable tissues. In the heart gap junctions allow current flows from the pacemaker cells to ventricular muscle cells leading to their synchronised rhythmic contraction. The exchange of second messengers allows the transfer of information between coupled cells. Metabolic coupling is particularly important in the case of non-vascularised tissues, such as the eye lens.

\subsection{The connexin family}

Gap junctions appeared during the evolutionary appearance of multicellular organisms. Innexins form gap junctions in invertebrates. Although their gene structure is very different from that of connexins, which form gap junctions in vertebrates, they exhibit remarkably similar channel properties (Phelan at al., 2001).

The multigene family of connexins has been divided into three types: $\alpha, \beta$ and $\gamma$ or $\delta$ (Fig.1) (Gimlich et al., 1990; Kumar and Gilula, 1992, Sohl et al., 1998; Manthey et al., 1999). 
Compared with the $\beta$ type connexins, the $\alpha$ type connexins have a larger M2-M3 cytoplasmic loop and a larger cytoplasmic $\mathrm{COOH}$-terminal tail (see Fig.3).

An alternative nomenclature uses the molecular weight to specify individual connexins (Beyer et al., 1990).

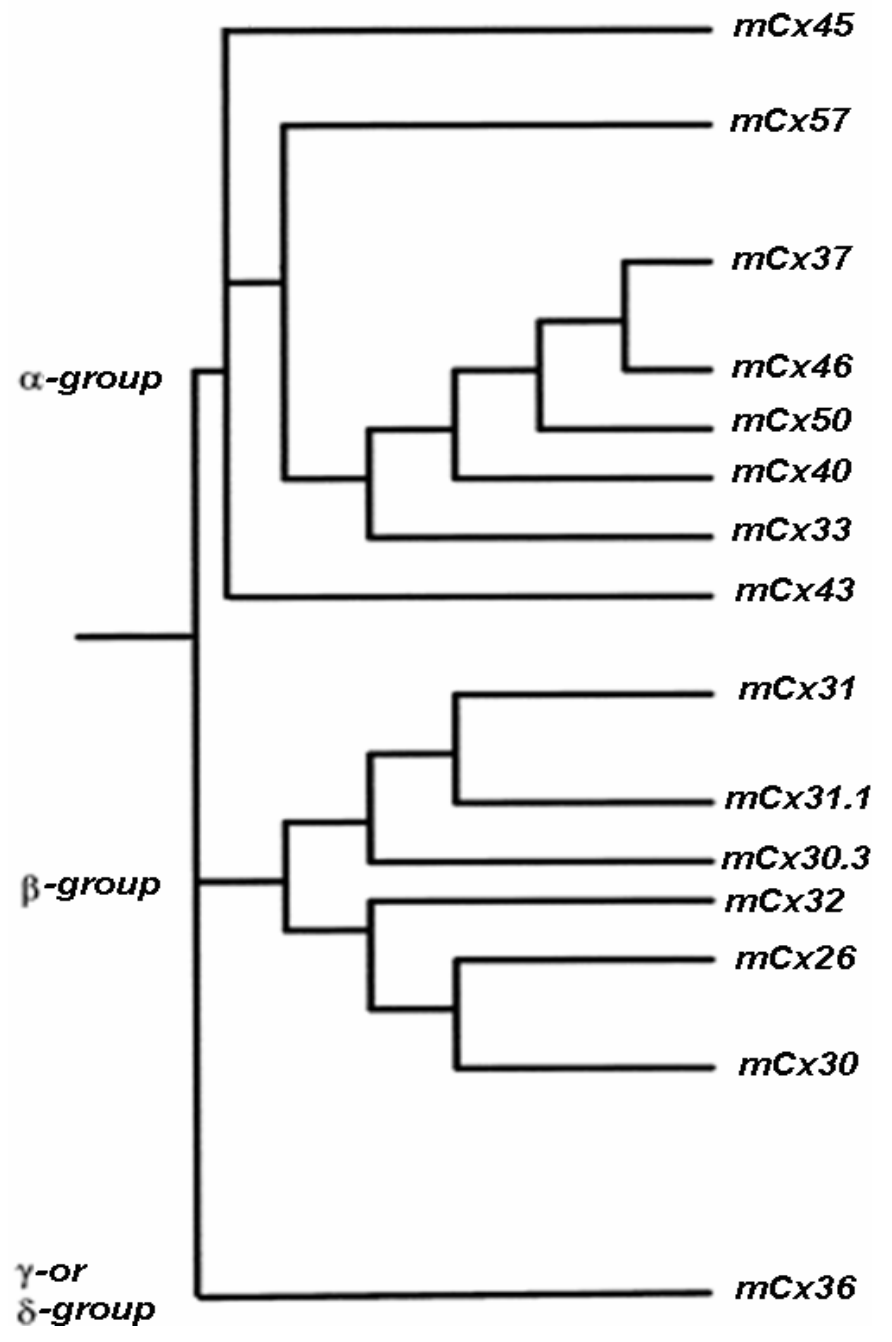

Fig.1 Phylogenetic tree of murine connexins. Taken from D. Manthey et al., JBC, 1999. 


\subsection{Transmembrane topology of connexins}

Docking of two hemichannels of adjacent cells forms gap junction. Each hemichannel (connexon) is composed of six subunits, called connexins (Cx) (Fig.2). Each connexin protein comprises four transmembrane, two extracellular and three cytoplasmic domains (Fig.3). The $\mathrm{N}$ - and C-termini of connexins are exposed into the cytoplasm. Major differences in sequence and length were found in the carboxyl terminal region and the cytoplasmic loop of connexins.

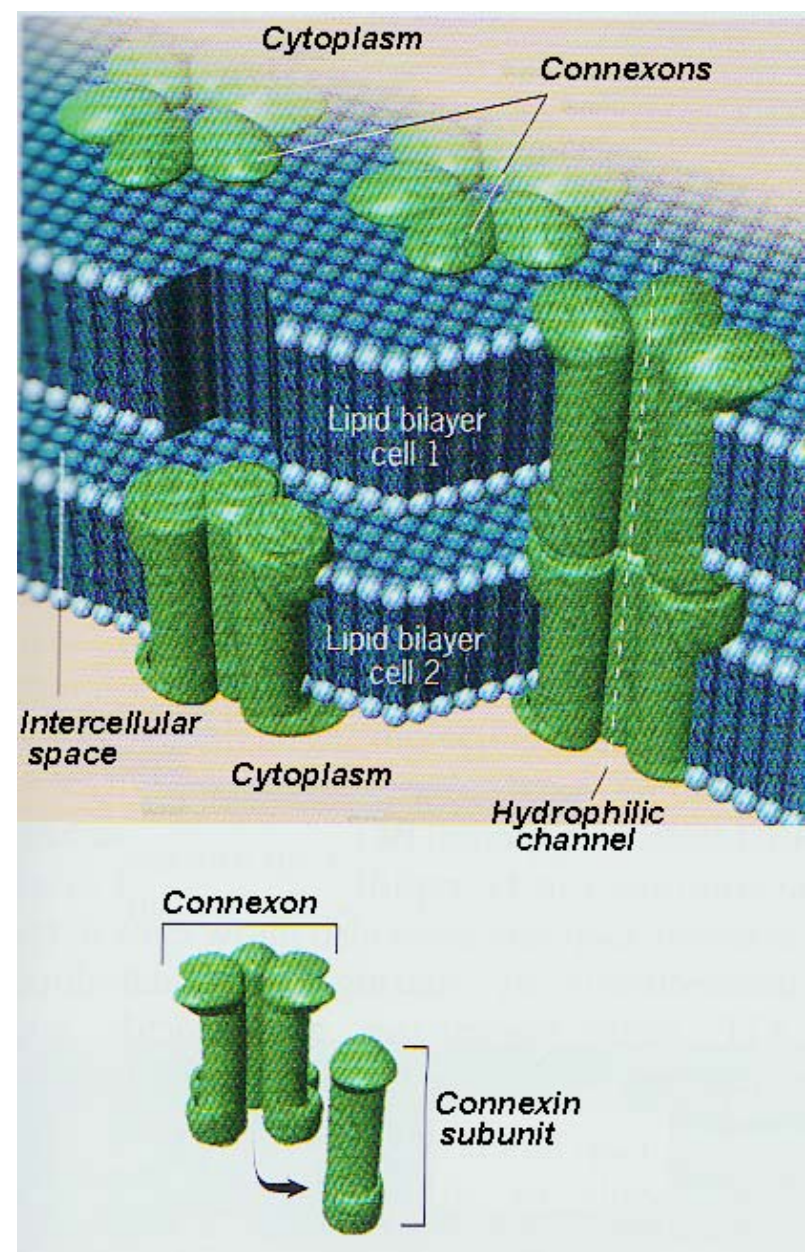

Fig.2 Schematic model of a gap junction channel. The gap junction channel consists of two hemichannels (connexons). Each connexon is composed of six protein subunits, called connexins. Taken from G.Karp, 1999. 


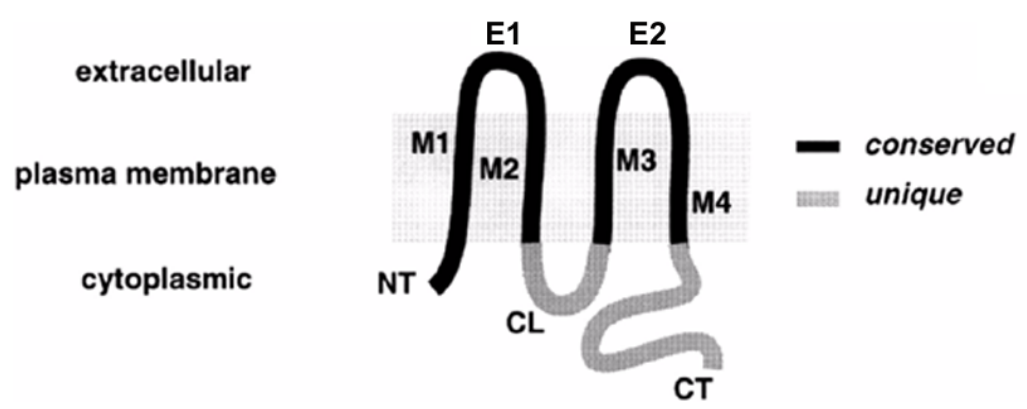

Fig.3 Schematic model of a connexin. Connexins are four times membrane crossing proteins with two extracellular loops and three cytoplasmic domains: N-terminus, intracellular loop and C-terminus. Taken from Nicholson et al., 1999.

Currently, 13 evolutionarily highly - conserved genes, which code for connexins, have been identified in mammalian tissues (White and Paul, 1999; Manthey et al., 1999; Teubner et al., 2001; Willecke et al., 2002). The same connexin can be expressed in different cell types and organs, and the same cell type can express different connexins.

Two connexons consisting of the same type of connexins can form a homotypic channel, whereas two connexons each consisting of different connexins can form a heterotypic gap junction channel. Connexin subunits within one connexon can form homoor heteromeric hemichannels. Heterotypic or heteromeric connexin channels have permeability properties corresponding to those of the subunits, forming the channel (Martinez et al., 2002; Moreno, 2002; Beyer et al., 2001).

\subsection{Intracellular trafficking of connexins}

Connexins, as many other secretory proteins, are inserted co-translationally into the membrane of the endoplasmic reticulum (ER). On the way to the plasma membrane connexins pass through the Golgi network (Musil et al., 1991; VanSlyke et al., 2000; Martin et al., 2001). Brefeldin A, which disrupts the Golgi apparatus, prevents the trafficking of $\mathrm{Cx} 32$ and $\mathrm{Cx} 43$; however, Cx26 still reaches the cell surface (Martin et al., 2001). Hexamerisation of connexins is a prerequisite for their transport to the plasma membrane. Multisubunit assembly of connexins occurs after exit from the ER (Musil and Goodenough, 1993). The installation of connexons occurs predominantly into the nonjunctional plasma membrane. These PM connexons can move laterally and reach the margins of gap junction channels cluster (Lauf et al., 2002). Removal of gap junctions 
from the plasma membrane occurs via endocytosis of the double membranous vesicle-like structures ("annular gap junctions") that are guided for degradation (Bjorkman 1962; Larsen and Tung, 1978; Ginzberg and Gilula, 1979; Laing and Beyer, 1995; VanSlyke et al., 2000).

\subsection{Connexin phosphorylation}

The majority of connexins are phosphoproteins (Traub et al., 1987,1989,1994; Crow et al., 1990, Musil at al., 1990; Saez et al., 1997, 1998). But only the phosphorylation of Cx43 is accompanied by an apparent molecular weight shift on SDS-polyacrylamide gels, forming a faster migrating, non-phosphorylated (NP) $43 \mathrm{kDa}$ isoform and at least two slower migrating isoforms commonly termed P1 (45 kDa) and P2 (47kDa).

$\mathrm{Cx} 43$ is phosphorylated in the ER or cis-Golgi compartment, displaying the Cx43-P1 isoform. The existence of the P2 isoform correlates with the appearance of connexin 43 on the plasma membrane and is necessary for the formation of functional gap junction channels (Musil and Goodenough, 1991;Laird et al, 1995).

Both, P1 and P2 isoforms contain predominantly phosphoserines (Crow et al, 1990).

Phosphorylation events can be involved in the oligomerisation of Cx43 into connexons, proper intracellular trafficking, formation and stabilisation of gap junctions, and degradation.

\subsection{Connexin degradation}

One of the most striking features of connexins is their rapid turnover. The half-life of Cx43 was found to be 1-3 h (Musil et al., 1991, 2000; Laird et al., 1991; Lampe, 1994). Such a dynamic turnover requires an efficient degradation mechanism to prevent the intracellular accumulation of $\mathrm{Cx} 43$.

As other transmembrane proteins, connexins are degraded in lysosomes after endocytosis. (Ginzberg and Gilula, 1979; Larsen et al., 1979). A study of Thomas and collegues (2003) suggests that the tyrosine-based motif of the C-terminus of connexin43 is responsible for lysosomal degradation of gap junctions.

A key question remained as to the role of proteasomes in the degradation of connexin. Recent studies revealed that proteasomal degradation would be the fate of the soluble pool of Cx43 dislocated from ER membranes (VanSlyke and Musil, 2002). It seems possible 
that as a quality control step missfolded or mutant connexins can become ubiquitinated and degraded by proteasomes as they pass through the ER (Qin et al., 2003).

\subsection{Interaction between connexins and protein partners}

The intracellular transport of connexins, gap junction plaque assembly and stability, and modulation of channel activity are most likely governed by interactions with regulatory and structural proteins that recognize specific sequence motifs in the cytoplasmic domains of connexins. However, only few such connexin-interacting proteins have been described to date, which include the tight junction protein $\mathrm{ZO}-1$, calmodulin, tubulin and certain protein kinases.

\subsubsection{Calmodulin directly gates gap junction channels}

Calmodulin $(\mathrm{CaM})$ is a calcium-binding protein that is considered a major transducer of calcium signals. Many of the proteins that $\mathrm{CaM}$ binds are unable to bind calcium themselves, and use $\mathrm{CaM}$ as a calcium sensor and signal transducer. Increased calcium intercellular concentrations lead to binding of calcium by $\mathrm{CaM}$, which subsequently undergoes a conformational change and binds to specific proteins for a specific response (James et al., 1995).

Recent data shows that $\mathrm{CaM}$ colocalizes with connexins and plays a direct role in gap junction channel gating (Peracchia et al., 1996, 2000; Sotkis et al., 2001; de Pina-Benabou et al., 2001).

Two cytoplasmically oriented sequences of Cx32, N-terminal (residues 1-21) and Cterminal (residues 216-230) have been shown to bind calmodulin in $\mathrm{Ca}^{2+}$-dependent manner (Torok et al., 1997). In addition, the binding of CaM to Cx32 in the absence of calcium partially prevents its phosphorylation by the EGF receptor tyrosine kinase (Diez et al., 1998).

\subsubsection{Association of connexins with Zonula occludens-1}

Zonula occludens-1 (ZO-1) is a peripheral membrane protein of approximately 210-225 $\mathrm{kDa}$, which is specifically enriched at tight junctions of epithelial and endothelial cells (Stevenson et al., 1986). ZO-1 tethers transmembrane proteins such as occludin, claudin and junctional adhesion molecules to the actin cytoskeleton (Denker and Nigam, 1998). It 
is a member of the membrane-associated guanylate kinase (MAGUK) family of proteins, which consists of three distinct amino acid motifs, namely: PSD95/Dlg/ZO-1 (PDZ) domains, an Src-homology-three domain (SH3) and a guanylate kinase domain (GonzalezMariscal et al., 2000).

ZO-1 has been shown to associate with $\mathrm{Cx} 43$ in different cell types (Toyofuku et al., 1998, 2001; Giepmans and Moolenaar, 1998; Giepmans et al., 2001). Interaction with ZO1 is dependent on the C-terminal isoleucine (DDLEI domain) of Cx43 (Giepmans and Moolenaar, 1998). Interesting, overexpression of a dominant-negative form of ZO-1, which is unable to associate with actin cytoskeleton, prevents $\mathrm{Cx} 43$ from localising to cell-cell contacts in cardiac myocytes, resulting in the decrease of electrical coupling via gap junctions (Toyofuku, 1998).

\subsubsection{Cadherins facilitate the formation of gap junctions}

Cadherins are transmembrane proteins whose extracellular domains promote calciumdependent homotypic adhesion between neighbouring cells, whereas their cytoplasmic regions are linked to the actin cytoskeleton by means of cytoplasmic proteins called catenins: $\alpha$-catenin, $\beta$-catenin and $\gamma$-catenins (Aberle et al., 1996).

Cell adhesion molecules are obvious candidates to facilitate the formation of gap junctions. The large extracellular domains of cadherins would likely prevent their actual inclusion into gap junctional plaques, however cadherins can act to position opposing membranes for gap junction channel formation (Jongen et al., 1991). Recent data suggest the intriguing possibility that these two classes of cell surface proteins can interact via a signal transduction system. Cell lines, deficient for cadherins, show diminished communications via gap junctions, which can be corrected by transfection with DNA coding for the appropriate cell adhesion molecules (Musil et al., 1990). Depletion of Ncadherin, using si-RNA, lead to the redistribution of $\mathrm{Cx} 43$ from the cell surface to the cytoplasm (Wei et al., 2003). Cx43 can be co-immunoprecipitated with N-cadherin, and also with other $\mathrm{N}$-cadherin-interacting proteins: $\alpha$-actinin, $\alpha$-catenin, p120 catenin, and LIN-7 (Wei et al., 2003; Singh and Lampe, 2003). 


\subsubsection{Protein kinases which phosphorylate connexin43}

Connexin43 contains in their $\mathrm{COOH}$-terminus a number of serin and tyrosin residues, which can be phosphorylated by several known and unknown protein kinases.

Oncogen v-Src tyrosin kinase promotes the direct phosphorylation of Cx43 on Tyr265 and Tyr247 in Cx43 (Kanemitsu et al., 1997, Lin et al., 2001). SH3 and SH2 domains of the $\mathrm{v}$-Src mediate this interaction with $\mathrm{Cx} 43$, inducing the disruption of gap junctional communication (Loo et al., 1995; Swenson et al., 1990; Filson et al., 1990; Crow et al., 1990, 1992).

Proto-oncogen c-Src tyrosine kinase, which is activated via G protein-coupled receptors in mammalian cells, also closes gap junctions by phosphorylation of Tyr265 (Postma et al., 1998). Moreover, the interaction of c-Src SH2 domain with C-terminus of connexin43 in parallel abolishes the interaction of $\mathrm{Cx} 43$ with $\mathrm{ZO}-1$ protein (Toyofuku et al., 2000).

PKC $\alpha$ can phosphorylate Cx43 on Ser368 and Ser372 in vitro (Saez et al., 1997). Ser368 is also a major site of phosphorylation in vivo. Phosphorylation of Cx43 on Ser368 decreases the number of cells transferring dye, enhances the relative frequency of a lower conductance state $(\sim 50 \mathrm{pS})$, and diminishes the relative frequency of the fully open state ( 100pS) of gap junctions (Lampe et al., 2000).

A cyclinB-dependent p34 cdc2 kinase regulates phosphorylation of $\mathrm{Cx} 43$ in mitotic cells (Lampe et al., 1998; Kanemitsu et al., 1998). This unique phosphorylation results in the redistribution of $\mathrm{Cx} 43$ from the plasma membrane and the subsequent loss of gap junctions.

Agents, that upregulate cAMP level and activate cAMP - dependent protein kinase (PKA) result in increase of intercellular communications via gap junctions (Darrow et al., 1996; Ten Broek et al., 2001).

Activation of mitogen-activated protein kinase (MAP) induces phosphorylation of serine 279 and serine 282 of Cx43 and disruption of gap junctional communication (WarnCramer et al., 1996).

Casein kinase 1 (CK1) has recently been found to phosphorylate Cx43 in vitro (Cheng and Louis, 2001; Cooper and Lampe, 2002). 


\subsubsection{Connexins and cytoskeletal proteins}

\subsubsection{Tubulin}

Microtubules play an important role in spatial organisation, cell polarity and directed movements of organelles in the cytoplasm. Connexons are delivered to the PM in vesicular carriers travelling along microtubules (Lauf et al., 2002). Cx43 forms complexes with $\beta$ tubulin in vitro (Giepmans et al., 2001). Nevertheless, nocodazole ( drug widely used to disrupt microtubules) affects forward transport of $\mathrm{Cx} 43$ from the Golgi to the PM only minimally (Paulson et al., 2000; Martin et al., 2001) and does not influence dye coupling or propagation of calcium waves via gap junctions (Branes et al., 2002).

\subsubsection{Actin}

The morphological integrity of the actin cytoskeleton seems to be fundamental for the functional activity of gap junctions, probably because of associations among actin filaments, actin binding proteins and connexin43 at the plasma membrane.

Microinjection of anti-actin antibodies prevents translocation of $\mathrm{Cx} 43$ from the Golgi apparatus to the cell membrane and blocks dye coupling (Theiss and Meller, 2002).

Disruption of microfilament by cytochalasin B inhibits the recruitment and assembly of Cx43 into gap junctions as indicated by fluorescence bleaching recovery experiments (Thomas et al., 2001). Several observations suggest that actin and myosin II are responsible for the removal of connexons from the plasma membrane (Murray et al., 1997). Other data propose a role of actin microfilaments for the process of clustering gap junctions into gap junctional plaques (Wang et Rose, 1995).

Cellular organisation is critical for the propagation of intercellular calcium signalling, mediated via gap junctions. Astrocytes in culture lost their capability for propagation of calcium waves when their actin cytoskeleton was disrupted by cytochalasin D treatment or affected by inhibition of myosin light chain kinase (Cotrina et al., 1998). 


\subsection{Connexin and signal transduction}

Gap junctions are widely involved in the intercellular transfer of information. Second messengers like inositol 1,4,5-trisphosphate, calcium or cyclic nucleotides may diffuse through gap junctions thus modulating cellular physiological activities of neighbouring cells (Berridge, 1997; Boitano et al., 1992, 1998; Sanderson, 1995; Robb-Gaspers and Thomas, 1995; Leybaert et al., 1998; Niessen et al., 2000; Guthrie et al., 1999).

Recent studies indicate that connexin hemichannels are also active and that they might be essential in intercellular signalling beyond their incorporation into gap junctions. Astrocytes express functional hemichannels that mediate an extracellular release of ATP (Cotrina et al., 1998; Stout et al., 2002), NAD ${ }^{+}$(Bruzzone et al., 2001; Ebihara, 2003), glutamate and aspartate (Innocenti et al., 2000; Ye et al., 2003).

Connexin43 hemichannels, but not gap junctions, are the essential transducers of the extracellular signal-regulated kinase (ERK), activating anti-apoptotic effects of bisphosphonates. Bisphosphonates, drugs used widely in the treatment of osteoporosis, prevent osteocyte apoptosis by a mechanism involving ERK activation (Plotkin and Belido, 2001; Plotkin et al., 2002). This observation adds Cx43 to the list of transmembrane proteins capable of transducing survival signals in response to extracellular cues and raises the possibility that it may be involved in mediating effect of endogenously produced molecules or even drugs.

\subsection{Dysfunction of connexins and human diseases}

The importance of gap junctions for the multicellular organisms is highlighted by a wide array of different human diseases and mouse phenotypes that arise from defects of these genes. In humans, the inherited defects in individual connexin isoforms are associated with demyelinating disorders of the peripheral nervous system, severe hearing impairment, eye lens cataracts, skin disorders, heart arrhythmias, and heart malformation. Such of these diseases have a significant impact on the human population, with Cx26 mutations accounting for more than $50 \%$ of the cases of inherited asyndromic sensorineural deafness (Willecke at al., 2002).

Diseases result from the impaired interactions of connexins with their protein partners. 
Disturbance of interaction with proteins of cellular trafficking machinery results in the absence of the wild-type connexins at the plasma membrane. In some cases connexins accumulate in the ER and induce a chronic endoplasmic reticulum stress response. Such a mechanism was suggested for the development of Charcot-Marie-Tooth peripheral neuropathy (Deschenes et al., 1997).

Disturbed protein-protein interactions of connexins with membrane-associated proteins also may lead to a major change in cell physiology and manifestation of diseases.

Thus, identification of new proteins, interacting with connexins provides a basis for clarifying the function of connexins at healthy and pathological conditions.

\begin{tabular}{|c|c|c|c|c|}
\hline $\begin{array}{l}\text { Mouse } \\
\text { connexin }\end{array}$ & Major expression & $\begin{array}{l}\text { Phenotype(s) of } \\
\text { Cx-deficient mice }\end{array}$ & $\begin{array}{l}\text { Human hereditary } \\
\text { disease(s) }\end{array}$ & $\begin{array}{l}\text { Human } \\
\text { connexin }\end{array}$ \\
\hline & n.a & n.a & n.a & $\mathrm{hCx} 25$ \\
\hline $\mathrm{mCx} 26$ & $\begin{array}{l}\text { breast, skin, coch- } \\
\text { lea, liver, placenta }\end{array}$ & lethal on ED11 & $\begin{array}{l}\text { sensorineural hearing } \\
\text { loss, palmoplantar } \\
\text { hyperkeratosis }\end{array}$ & $\mathrm{hCx} 26$ \\
\hline $\mathrm{mCx} 29$ & myelinated cells & n.a & n.a & $\mathrm{hCx} 30.2$ \\
\hline $\mathrm{mCx} 30$ & $\begin{array}{l}\text { skin, brain, } \\
\text { cochlea }\end{array}$ & $\begin{array}{l}\text { hearing } \\
\text { impairment }\end{array}$ & $\begin{array}{l}\text { nonsyndromic hearing } \\
\text { loss, hydrotic } \\
\text { ectodermal dysplasia }\end{array}$ & $\mathrm{hCx} 30$ \\
\hline $\mathrm{mCx} 30.2$ & n.a & n.a & n.a & $\mathrm{hCx} 31.9$ \\
\hline $\mathrm{mCx} 30.3$ & skin & n.a. & $\begin{array}{l}\text { erythrokeratodermia } \\
\text { variabilis }(\mathrm{EKV})\end{array}$ & $\mathrm{hCx} 30.3$ \\
\hline $\mathrm{mCx} 31$ & skin, placenta & $\begin{array}{l}\text { transient placental } \\
\text { dysmorphogenesis }\end{array}$ & $\begin{array}{l}\text { Hearing impairment, } \\
\text { erythrokeratodermia } \\
\text { variabilis(EKV) }\end{array}$ & $\mathrm{hCx} 31$ \\
\hline $\mathrm{mCx} 31.1$ & skin & n.a & n.a & $\mathrm{hCx} 31.1$ \\
\hline $\mathrm{mCx} 32$ & $\begin{array}{l}\text { liver, Schwann } \\
\text { cells, } \\
\text { olygodendrocytes }\end{array}$ & $\begin{array}{l}\text { decreased } \\
\text { glycogen } \\
\text { degradation, } \\
\text { increased liver } \\
\text { carcinogenesis }\end{array}$ & $\begin{array}{l}\text { CMTX, (hereditary } \\
\text { peripheral neuropathy) }\end{array}$ & $\mathrm{hCx} 32$ \\
\hline $\mathrm{mCx} 33$ & testis & n.a. & & \\
\hline $\mathrm{mCx} 36$ & neurones & visual deficits & n.a. & $\mathrm{hCx} 36$ \\
\hline $\mathrm{mCx} 37$ & endothelium & female sterility & n.a & $\mathrm{hCx} 37$ \\
\hline $\mathrm{mCx} 39$ & n.a & & n.a & $\mathrm{hCx} 40.1$ \\
\hline $\mathrm{mCx} 40$ & heart, endothelium & atrial arrhythmias & n.a & $\mathrm{hCx} 40$ \\
\hline $\mathrm{mCx} 43$ & many cell types & heart malformation & $\begin{array}{l}\text { visceroatrial } \\
\text { heterotaxia }\end{array}$ & $\mathrm{hCx} 43$ \\
\hline $\mathrm{mCx} 45$ & $\begin{array}{l}\text { heart, smooth } \\
\text { muscle, neurones }\end{array}$ & lethal on ED10. 5 & n.a & $\mathrm{hCx} 45$ \\
\hline
\end{tabular}




\begin{tabular}{|c|c|c|c|c|}
\hline $\mathrm{mCx} 46$ & Lens & $\begin{array}{l}\text { zonular nuclear } \\
\text { cataract }\end{array}$ & congenital cataract & $\mathrm{hCx} 46$ \\
\hline $\mathrm{mCx} 47$ & brain, spinal cord & n.a & n.a & $\mathrm{hCx} 47$ \\
\hline $\mathrm{mCx} 50$ & lens & $\begin{array}{l}\text { microphthalmia, } \\
\text { zonular } \\
\text { pulverulent and } \\
\text { congenital cataract }\end{array}$ & $\begin{array}{l}\text { zonular pulverulent } \\
\text { cataract }\end{array}$ & $\mathrm{hCx} 50$ \\
\hline & n. a & n.a & n.a & $\mathrm{hCx} 59$ \\
\hline $\mathrm{mCx} 57$ & ovaries & n.a & n.a & hCx62 \\
\hline
\end{tabular}

Tab.1 Summary of currently known mouse and human connexin genes. Taken from K.Willecke et al., 2002. 


\section{Aim of this work}

1. To identify new proteins, which are involved in the intercellular trafficking and plasma membrane appearance of connexin 43.

2. To identify new proteins, interacting with connexin 43 , which are required for the functional activity of gap junctions.

3. To confirm these protein-protein interactions in live cells.

4. To analyse the functional importance of identified protein-protein interactions. 


\title{
Materials
}

\section{Chemicals}

All chemicals used were of analytical grade and were purchased from Merck, Sigma, Boehringer or Serva.

\section{Cell culture}

Dulbecco's modified Eagle's medium (DMEM) was from Life Technologies, fetal calf serum from Biochrom/Seromed, trypsin-EDTA from Gibco BRL. Greiner provided all culture dishes. Oligofectamine for si-RNA transfection and Lipofectamine 2000 for cDNA transfection were from Invitrogen.

\begin{abstract}
Antibodies
Polyclonal antibodies directed against connexin 43 were from Sigma. Polyclonal antibodies against the first extracellular loop of connexin 43 were raised in rabbits according to standard procedures. Polyclonal antibodies against the KDEL receptor were from Dr. I. Majoul (Dept. of Neurobiology, Max-Planck-Institute for Biophysical Chemistry, Göttingen, Germany). Monoclonal antibodies against drebrin (M2F6) were from StressGen and from Dr. T. Shirao (Gunma University Graduate School of Medicine, Maebashi, Japan).
\end{abstract}

Secondary antibodies coupled to $\mathrm{Cy} 3$ or $\mathrm{Cy} 2$ were purchased from Dianova.

\section{Standard molecular biology components}

Plasmid DNA extraction from E. coli, DNA extraction from agarose gel and purification of PCR products were performed with a Qiagen Spin MiniPrep or MaxiPrep Kit, a QIAquick Gel Extraction Kit, a PCR Purification Kit (Dianova). SuperSignal Substrate Kit (Pierce) was used for chemiluminescence.

Restriction enzymes were from Gibco/BRL, Boehringer or New England Biolabs. T4polymerase and T4-DNA ligase from Amersham Pharmacia. Pfu polymerase was from Boehringer. 
NAP10 and P20 columns (Amersham Pharmacia) were used for desalting/rebuffering of synthetic oligonucleotides and proteins, respectively. Nitrocellulose membranes for Western blotting were from Sartorius, polyvinylidene-difluoride (PVDF) membranes from Millipore. Glutation Sepharose 4B and Protein A Sepharose came from Amersham Pharmacia, protease inhibitors mix "Complete" was from Roche.

\section{cDNA and fluorescent protein constructs}

Connexin43 cDNA was from Dr. K. Willecke (University of Bonn, Germany), cDNA coding for drebrin-GFP from Dr. T. Shirao (Gunma University Graduate School of Medicine, Maebashi, Japan), GFP-actin from Dr. S. Kuznetzov (University of Rostok, Germany), Sec13-YFP, Sar1 dn and ARF1, ARF1 Q71L-GFP and p23-CFP from Dr. R. Duden (University of Cambridge, UK)

The si-RNA duplex against drebrin was synthesised by Dharmacon (www.Dharmacon com.).

Plasmid vector pGEX-4T3 was from Amersham Pharmacia.

Bacterial E.coli strains: DH5 $\alpha$ was from Gibco-BRL, XL1-Blue from Stratagene. Mammalian tissue culture cell lines Vero (African green monkey kidney) and COS (SV40 transformed African green monkey kidney) were from ATCC.

IPTG was used for induction of protein synthesis at $0.5 \mathrm{mM}$ final concentration for liquid culture from $1 \mathrm{M}$ filtered stock.

LatrunculinB (disrupts actin microfilament organisation) was used from a $5 \mathrm{mg} / \mathrm{ml}$ stock in $\mathrm{EtOH}$ at $50 \mathrm{nM}$ final concentration.

Lucifer yellow $\mathrm{CH}$ and calcein (Molecular Probes, Eugene, OR) were used for microinjection. 


\section{Frequently used buffers:}

PBS (phosphate buffered saline):

$\begin{array}{ll}\mathrm{NaCl} & 137 \mathrm{mM} \\ \mathrm{KCl} & 2.7 \mathrm{mM} \\ \mathrm{Na}_{2} \mathrm{HPO}_{4} & 8.1 \mathrm{mM} \\ \mathrm{KH}_{2} \mathrm{PO}_{4} & 1.4 \mathrm{mM}, \mathrm{PH} 7.4\end{array}$

Cytomix buffer:

$\mathrm{KCl}$

$120 \mathrm{mM}$

$\mathrm{KH}_{2} \mathrm{PO}_{4}$

$10 \mathrm{mM}$

EGTA

$2 \mathrm{mM}$

$\mathrm{MgCl}_{2}$

$5 \mathrm{mM}$

Hepes

$25 \mathrm{mM}$

$\mathrm{CaCl}_{2}$

$0.15 \mathrm{mM}$

GSSG

$5 \mathrm{mM}$

ATP

2 mM, PH 7.4 


\section{Methods}

\subsection{Construction of pGST-CT-Cx43}

To create the GST-COOH-terminus-Cx43 (GST-CT-Cx43) construct the relevant part of rat heart connexin 43 cDNA was amplified by PCR. The sequences of the primers were as follows: forward primer: 5'-CTAGGGATCCAAGGGCGTTAAGGATCGCGTG AAG; reverse primer: 5'-CTAGGCGGCCGCTAAAATCTCCAGGTCATCAGG.

The PCR product was restricted with BamHI and Not I and ligated into the BamHI/Not I sites of pGEX-4T-3. This placed the C-terminus of $\mathrm{Cx} 43$ sequence in frame with the upstream GST sequence. The correct sequence of the GST-CT-Cx43 construct was verified by DNA- sequencing.

1

40 gtccaagcct actccaccgc

101 atcctgctcc tggggacagc

161 tgtaacactc aacaacctgg

221 cacgtgcgct tctgggtcct tc

281 gcccatgtgt tctatgtgat

341 aaagtggccc agactgacgg

401 aagttcaagt acgggattga ag

461 acctacatca tcagcatcct ct

521 tggtacatct atgggttcag

581 caccaggtag actgcttcct ct

641 ctggtggtgt ccttggtgtc tc

701 aaaggcgtta aggatcgcgt g

761 ctgagcccat caaagactg cggatctcca aa

821 ccaacggctc cactctcgcc tatgtctcct cct

881 aacaattcct cgtgccgcaa ttacaacaag ca

941 agcgcagagc aaaatcgcat ggggcaggcc gg

100

1061cagccattag ccatcgtgga ccaacgacct tccagcagag coagcagccg cgccagcagc

1121 aggcctcggc ctgatgacct ggagattta

Fig. 4 Sequence of connexin43 gene (NCBI accession number x06656). C-terminus of Cx43 (aa $\left.a_{234}-a_{382}\right)$ used for cloning into pGEX-4T-3 shown in bold. 


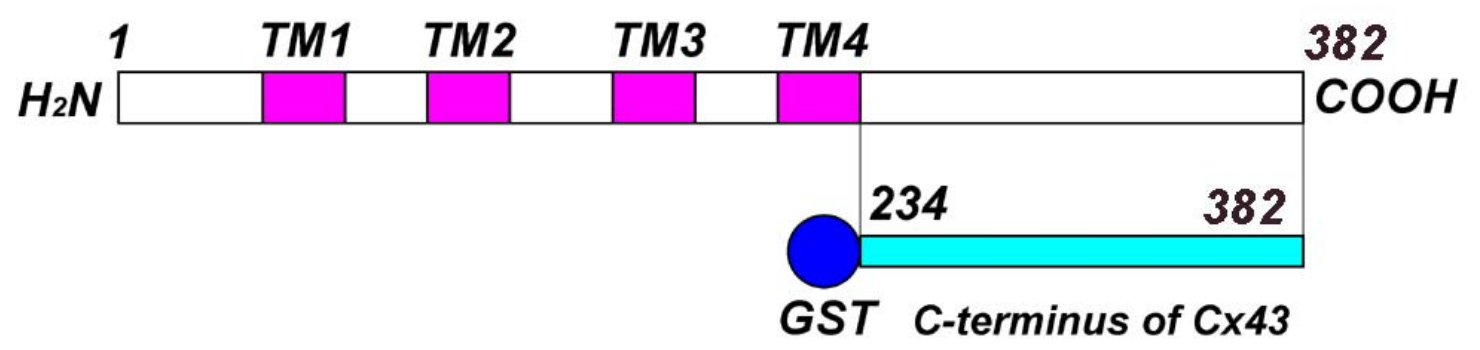

Fig.4 Schematic representation of connexinx 43 and GST-C-terminusCx 43 construct used in pull down experiment.

\subsection{Expression and purification of GST-CT-Cx43 protein}

LB medium ( $5 \mathrm{ml})$ with $50 \mu \mathrm{g} / \mathrm{ml}$ ampicillin was inoculated with 1 colonie of E.Coli harbouring the vector construct pGEX-CT-Cx43 and incubated for $8 \mathrm{~h}$ at $37^{\circ} \mathrm{C}$ with shaking about 200 rotation/min. 1 liter of LB medium with $50 \mu \mathrm{g} / \mathrm{ml}$ ampicillin was inoculated with $1 \mathrm{ml}$ of the preculture and incubated overnight at $24^{\circ} \mathrm{C}$ with shaking at about 200 rotations/min till an $\mathrm{A}_{600}$ of $1.0-1.2$. $0.5 \mathrm{ml}$ of $1 \mathrm{M}$ IPTG was added to induce synthesis of GST-fusion protein. After $3 \mathrm{~h}$ cells were harvested by centrifugation at $5,000 \mathrm{x}$ g for $5 \mathrm{~min}$ at $4^{\circ} \mathrm{C}$, washed in ice-cold PBS and centrifuged again under the same conditions. Bacterial sediments were resuspended in $20 \mathrm{ml}$ of ice-cold PBS containing 1 tablet of protease inhibitors mix "Complete" and $20 \mathrm{mg}$ lysozyme and incubated on ice for $15 \mathrm{~min}$. Then cells were disrupted by sonication (15 bursts 5 times at maximum output setting) on a Branson model 250 Sonifier while the sample was kept in an ice-water mixture.

Triton X-100 (final concentration 1\% (v/v)) was added and the lysate was incubated for $30 \mathrm{~min}$ on ice with gentle agitation. Thereafter, the sample was spun at 12,000x g for 10 min at $4{ }^{\circ} \mathrm{C}$. The supernatant was added to $1 \mathrm{ml}$ of a $50 \%$ slurry of Glutathion Sepharose $4 \mathrm{~B}$ in PBS. Then the sample was rotated for $30 \mathrm{~min}$ at $4^{\circ} \mathrm{C}$ for binding GSTfusion protein to Glutathion Sepharose beads. After this procedure the sample was spun for $5 \mathrm{~min}$ at $500 \mathrm{x} \mathrm{g}$, the resin was collected and washed again 5 times with $20 \mathrm{ml}$ each of cold PBS. 
Where indicated the GST-fusion protein was eluted with elution buffer ( $5 \mathrm{mM}$ Glutathion-SH in $50 \mathrm{mM}$ Tris $\mathrm{HCl}, 50 \mathrm{ml}, \mathrm{pH}$ 8.0). $1 \mathrm{ml}$ of elution buffer was added to the resin, the mixture was rotated for $5 \mathrm{~min}$ at RT, spun at 500x $\mathrm{g}$ for $3 \mathrm{~min}$, and the supernatant transferred to a fresh tube. The elution step was performed twice more, using the same resin. The eluted GST-CT-Cx43 protein fractions were combined, aliquoted, and stored at $-80^{\circ} \mathrm{C}$.

\subsection{Preparation of fractions for pull down assay}

The fresh mouse organs (brain, kidney, liver, spleen, and heart) were homogenised with $2 \mathrm{ml}$ of "Cytomix" buffer containing the "Complete" protease inhibitor coctail. The homogenates were centrifuged in a Beckman TLA 100.3 rotor for $45 \mathrm{~min}$ at 50,000 rpm (about100,000 x g) at $4^{\circ} \mathrm{C}$.

The supernatants were used in the experiments as "cytosolic fraction". The pellets were resuspended in $2 \mathrm{ml}$ of the same buffer, but containing TritonX-100 to $1 \%$ and centrifuged under the same conditions. The supernatants were used in experiment as "membrane fractions".

\subsection{Pull down using Glutathione Sepharose fusion protein}

The cytosolic and membrane fractions were pre-cleared by incubating with $300 \mu$ of Glutathione Sepharose 4B beads bound to GST for $1.5 \mathrm{~h}$ at $4{ }^{\circ} \mathrm{C}$ on a rotating platform. The samples were centrifugated at 500x g for $3 \mathrm{~min}$ and the supernatant was used.

The pre-cleared cytosol was then incubated with $300 \mu 1$ of Glutathione Sepharose 4B beads bound to the GST-fusion protein for $1.5 \mathrm{~h}$ at $4^{\circ} \mathrm{C}$ on a rotating platform.

The beads were washed 5 times in " Cytomix " buffer containing " Complete " protease inhibitor coctail and 1\% Triton X-100.

The samples were boiled for $2 \mathrm{~min}$ in $60 \mu \mathrm{l} 2 \mathrm{x}$ SDS-PAGE sample buffer containing $0.1 \%(\mathrm{v} / \mathrm{v}) \beta$-mercaptoethanol. The liquid phases were collected and $12 \%$ SDS-PAGE was carried out. 


\subsection{PCR}

This method utilises a primer pair complementary to the respective $3^{\prime}$ ends of the region of interest in a double-stranded DNA template, a temperature stable DNA polymerase such as Taq polymerase and a thermocycler device to generate a vast amount of identical copies of the intervening sequence.

The annealing temperature $(\mathrm{T})$ was determined for each primer pair separately by the following empirical relationship: $\mathrm{T}\left({ }^{\circ} \mathrm{C}\right)=69.3+0.41 \times(\mathrm{GC} \%)-650 / 1$, where $1=($ overlap length in bases $)$ The lower of the two temperatures values for a primer pair was used in the reaction. Taq DNA polymerase activity was taken as 1000 bp per min.

\section{Typical reaction mixture:}

50 ng template DNA $(\sim 1 \mu \mathrm{l})$

50-100 pmol forward primer $(1 \mu \mathrm{l})$

50-100 pmol reverse primer $(1 \mu \mathrm{l})$

$1 \mu \mathrm{l} 10 \mathrm{x}$ dNTP mix

$5 \mu \mathrm{l}$ 10x Taq buffer

add double-distilled $\mathrm{H}_{2} \mathrm{O}$ to $50 \mu \mathrm{l}$

mix

add $1 \mu$ Taq polymerase

\section{Typical PCR programme:}

$1.94^{\circ} \mathrm{C} 4 \mathrm{~min}$ denaturation

2. $94^{\circ} \mathrm{C} 50 \mathrm{sec}$ denaturation

3. $62^{\circ} \mathrm{C} 25 \mathrm{sec}$ annealing

4. $72^{\circ} \mathrm{C} 30 \mathrm{sec}$ extension

5. 30 cycles steps 2 to 4

6. $4^{\circ} \mathrm{C} \quad$ cooling 


\subsection{DNA-gel electrophoresis}

In TBE buffer ( $\mathrm{pH}$ 8.1) the negatively charged DNA molecules migrate under the influence of an electrical field from the cathode to the anode. The distance migrated is dependent on fragment size and fairly independent of base sequence. The bands are made visible under ultraviolet light of $302 \mathrm{~nm}$ after staining of the gel with ethidium bromide solution.

TBE buffer:

$50 \mathrm{mM}$ Tris

1 mM EDTA

$500 \mathrm{mM} \mathrm{H}_{3} \mathrm{BO}_{3}$

pH 8.1

Ethidium bromide $0.1 \mathrm{mg} / \mathrm{ml}$

$1 \%$ agarose gels were used. TBE buffer $(100 \mathrm{ml})$ was added to $1 \mathrm{~g}$ of agarose and boiled in a microwave oven until the agarose had completely dissolved. After cooling to about $60^{\circ}$ the gel was cast in a special chamber. To increase the density of the applied samples and to allow monitoring of the progress of the electrophoresis, 0.2 volume Blue marker was added to the samples. The gels were run in TBE at $70-80 \mathrm{~mA}$ for $10 \times 10 \mathrm{~cm}$ gels for about $60 \mathrm{~min}$. Then gels were stained with ethidium bromide for $15 \mathrm{~min}$. Documentation was performed with a Biometra CCD camera.

\subsection{Purification of PCR products}

DNA was purified using a QIAGEN extraction kit according to the manufacturer's instructions.

\subsection{DNA sequence analysis}

DNA sequence analysis was performed by the Sanger method by SecLab, Goettingen. 


\subsection{Estimation of DNA purity and concentration}

DNA concentration was estimated from the absorption at $260 \mathrm{~nm}$ using a Gene Quant II (Pharmacia) device. For DNA concentration, the approximate relationship was used that an $\mathrm{A}_{260}$ of 1.0 corresponds to ca. $50 \mu \mathrm{g} / \mathrm{ml}$ double-stranded DNA, to $40 \mu \mathrm{g} / \mathrm{ml}$ singlestranded DNA, and to $31 \mu \mathrm{g} / \mathrm{ml}$ oligonucleotide DNA.

\subsection{Restriction enzyme digestion}

The DNA fragment coding a partial sequence of $\mathrm{Cx} 43\left(\mathrm{aa}_{234}-\mathrm{aa}_{381}\right)$ was digested with BamH1 and Not1.

Reaction mixture:

$5 \mu \mathrm{g}$ DNA

$2 \mu \mathrm{l}$ (20 unit) BamH1

$2 \mu \mathrm{l}(20$ unit) Not1

$6 \mu 1$ restriction buffer

add $\mathrm{H}_{2} \mathrm{O}$ to $60 \mu \mathrm{l}$

Incubation for $1 \mathrm{~h}$ at $37^{\circ} \mathrm{C}$

Restricted DNA was purified by gel electrophoresis followed by extraction from the gel.

\subsection{Ligation}

Sticky-end ligation was carried out at room temperature for 2-4 h, typically using a 1:1 - 5:1 insert:vector molar ratio and T4 DNA ligase.

Typical reaction mixture:

150-300 ng insert DNA

50-100 ng vector DNA

$5 \times 44$ ligase buffer $4 \mu 1$

add $\mathrm{H}_{2} \mathrm{O}$ to $19 \mu 1$

add $1 \mu \mathrm{l}$ (400 unit) T4 DNA ligase 


\subsection{Preparation of competent $E$. coli cells for heat shock transformation}

LB-medium $(250 \mathrm{ml})$ was inoculated with cells of the desired strain. Overnight culture was harvested at an $\mathrm{A}_{600}$ of $0.5-0.9$ by centrifugation $\left(4,000 \mathrm{x} \mathrm{g}, 10 \mathrm{~min}\right.$ at $\left.4^{\circ} \mathrm{C}\right)$. The cells were cooled on ice for $30 \mathrm{~min}$ and then washed twice with ice cold water and once with $25 \mathrm{ml}$ sterile filtered TB followed by centrifugation at 7,000 x g for $5 \mathrm{~min}$ at $4^{\circ} \mathrm{C}$. Cells were then resuspended once more in $5 \mathrm{ml} \mathrm{TB}$. Aliquots $(300 \mu \mathrm{l})$ were taken and stored at $-80^{\circ} \mathrm{C}$ in the presence of $7 \%(\mathrm{v} / \mathrm{v})$ DMSO unless used immediately.

\section{Transformation buffer:}

PIPES $10 \mathrm{mM}$

$\mathrm{MnCl}_{2} 55 \mathrm{mM}$

$\mathrm{CaCl}_{2} 15 \mathrm{mM}$

$\mathrm{KCl} 250 \mathrm{mM}$

in bidest. water, $\mathrm{pH} 6.7$ is set before addition of $\mathrm{MnCl}_{2}$

\subsection{Preparation of electro-competent E.coli cells}

An overnight culture (1 ml) of E.coli XL1-Blue cells was used to inoculate 11 of fresh $\mathrm{LB}$ medium. The culture was grown at $37^{\circ} \mathrm{C}$ with agitation for about $2.5 \mathrm{~h}$ untill an $\mathrm{A}_{600}$ of 0.5-0.8 was achieved. The flask was cooled on ice for about $30 \mathrm{~min}$, and the cells were collected by centrifugation at $4,000 \mathrm{x}$ g for $20 \mathrm{~min}$ at $4{ }^{\circ} \mathrm{C}$. The cells were washed subsequently with 11 of ice cold sterile HEPES buffer, $500 \mathrm{ml}$ HEPES buffer, and $20 \mathrm{ml}$ HEPES buffer with $10 \%(\mathrm{v} / \mathrm{v})$ glycerol, followed by centrifugation. Finally cells were resuspended in $2-3 \mathrm{ml}$ sterile $10 \%$ (v/v) glycerol and aliquoted. Samples $(100 \mu \mathrm{l})$ were frozen on dry ice and stored at $-80^{\circ} \mathrm{C}$.

HEPES buffer: 1 mM HEPES, pH 7.0

HEPES/glycerol: 1 mM HEPES, pH 7.0; 10\% (v/v) glycerol $10 \%$ glycerol: $10 \%(\mathrm{v} / \mathrm{v})$ glycerol in bidest. water All solutions were sterilised by autoclaving before use. 


\subsection{Transformation of $E$.coli by electroporation}

Electro-competent E.coli XL1-Blue cells $(50 \mu \mathrm{l})$ were thawed on ice and transferred to a chilled $0.1 \mathrm{~cm}$ electroporation cuvette. Plasmid DNA $(1.0 \mu \mathrm{g})$ was added. The cuvette was placed into a Gene Pulser electroporator (BioRad) and pulsed once with 1800 $\mathrm{V}, 25 \mu \mathrm{F}, 20 \mathrm{Ohms}$. The discharge time was usually about 4,5- $5 \mathrm{~ms} .1 \mathrm{ml} \mathrm{LB}$ medium was added immediately after electroporation and the sample was incubated with agitation at $37^{\circ} \mathrm{C}$ for $1 \mathrm{~h} .100 \mu \mathrm{l}$ of this culture were plated onto LB-Ampicillin or LB-Kanamycin plates and incubated overnight at $37^{\circ} \mathrm{C}$.

\subsection{Precepitation of DNA using plasmid mini and maxi-preps}

Small- or large-scale plasmid extractions were performed using Plasmid Mini-and Maxi-Prep kits from Quiagen according to the manufacturer's recommendations. The basic principle involves alkaline lysis of the cell wall, degradation of RNA by RNase, precipitation of proteins and chromosomal DNA with high salt, binding of plasmid DNA to a silica-gel matrix, elution and precipitation with isopropanol and ethanol.

\subsection{Antibodies}

\subsubsection{Covalent linking of peptides to carrier protein using the bifunctional reagent sulfo-SMCC}

Keyhole limpet hemocyanin (KLH, Pierce) was used as a carrier protein for synthetic peptides. Synthetic peptide raised against the first extracellular loop of connexin43 (aa46aa68) was coupled via their C-terminal Cys residues to primary amines (mainly to Lys side chains) using the bifunctional reagent sulfosuccinimidyl 4-(N-maleimidomethyl) cyclohexane-1-carboxylate (sulfo-SMCC, Pierce).

$20 \mathrm{mg}$ of $\mathrm{KLH}$ in $2 \mathrm{ml}$ bidest. $\mathrm{H}_{2} \mathrm{O}$ was activated by incubation with $3 \mathrm{mg}$ sulfo-SMCC

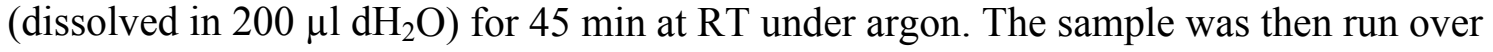
a G-25 column to remove non-reacted sulfo-SMCC and the first peak, measured at 280 $\mathrm{nm}$, was pooled. The $\mathrm{pH}$ of the pooled fractions was then set to 7.15. The coupling reaction was initiated by adding $20 \mathrm{mg}$ of the Cys-containing peptide, dissolved in bidest. $\mathrm{H}_{2} \mathrm{O}$, and the mixture allowed to proceed for ca. $5 \mathrm{~h}$ at $\mathrm{RT}$ with end-over-end rotation. 
Thereafter, the sample was dialysed extensively against PBS, aliquoted into $500 \mu \mathrm{g}$ protein aliquots, and stored at $-20^{\circ} \mathrm{C}$ until used for immunisation.

\subsubsection{Rabbit immunization}

Initially $10 \mathrm{ml}$ of blood was taken before the first immunisation to obtain pre-immune serum. For the first injection, $500 \mu \mathrm{g}$ of coupled peptide, $1 \mathrm{ml}$ Freund's complete adjuvant and $50 \mu \mathrm{g}$ muramyl dipeptide were mixed to get a thick emulsion. This suspension was injected subcutaneously and intracutaneously according to standard procedure.

\subsubsection{Purification of antibodies}

Anti-serum $(10 \mathrm{ml})$ was applied to a column holding $1 \mathrm{ml}$ of Protein A Sepharose prewashed with PBS. Binding of IgG proteins was allowed to proceed overnight at $4^{\circ} \mathrm{C}$ by slowly circulating the serum repeatedly over the column with the aid of a peristaltic pump. The column was then washed with PBS until all unbound proteins had been washed out (measured at $\mathrm{A}_{280}$ ). Bound IgG was eluted in one step with $3 \mathrm{ml} 100 \mathrm{mM}$ sodium citrate $(\mathrm{pH} 3.2)$. Eluted proteins were collected in $1.5 \mathrm{ml}$ tubes already containing sufficient neutralisation buffer $(300 \mu 11 \mathrm{M}$ Tris/HCl, pH9.0) for immediate neutralisation.

\subsection{Determination of protein concentration}

Protein concentrations were estimated according to Bradford (Bradford, 1976). Briefly, the absorption of a protein-specific dye, Coomassie Brilliant Blue, is measured near $595 \mathrm{~nm}$. This absorption, which is due to interactions with basic or aromatic residues, yields relatively good linear concentration dependence for most soluble proteins. Protein solutions of unknown concentration are measured and the absorbance

plotted against a reference curve obtained with a protein of known concentration (BSA). From this an approximate concentration is determined.

\section{Staining solution:}

100mg Coomassie Brilliant Blue G 250

$50 \mathrm{ml} \mathrm{95 \%} \mathrm{(v/v)} \mathrm{ethanol}$ 
$100 \mathrm{ml} \mathrm{85 \%} \mathrm{(v/v)} \mathrm{phosphoric} \mathrm{acid}$

add $\mathrm{H}_{2} \mathrm{O}$ to 1 litre and filter the solution.

The dye was first dissolved in ethanol before addition of the other components. The solution was filtered before use. A few (1-10) $\mu \mathrm{l}$ of the protein sample were added to $1 \mathrm{ml}$ dye solution. The mixture was incubated for $5 \mathrm{~min}$ at room temperature and OD at $\mathrm{A}_{578}$ was measured. As reference, an identical amount of protein solvent solution was treated similarly. Determination of the protein concentration was based on the concentration curve of bovine serum albumin $(1-10 \mu \mathrm{g})$ from which the factor of the staining solution was calculated. The factor is the ratio of the weight of bovine serum albumin to OD at $\mathrm{A}_{578}$ in the linear region of the standard curve.

Protein concentration $(\mu \mathrm{g} / \mu \mathrm{l})=(\Delta \mathrm{OD} \times$ Factor $\mathrm{x}$ Dilution $) /$ Volume of protein solution

\subsection{Subcellular fractionation of cultured cells}

Vero cells (ATCC) grown in a monolayer for $36 \mathrm{~h}$ in a $14.5 \mathrm{~cm}$ Peri dish were surface-biotinylated on ice for $10 \mathrm{~min}$. Excess of unbound biotin was removed by washing the cells with ice-cold PBS. Cells were detached from Petri dishes after exposure to $10 \mathrm{mM}$ EGTA in PBS and transferred on ice into "internal medium".

\begin{tabular}{lr} 
"internal medium": \\
\hline K glutamate & $130 \mathrm{mM}$ \\
sucrose & $20 \mathrm{mM}$ \\
$\mathrm{NaCl}$ & $20 \mathrm{mM}$ \\
EGTA & $2 \mathrm{mM}$ \\
ATP & $2 \mathrm{mM}$ \\
glutathione & $5 \mathrm{mM}$ \\
pH 7.6 &
\end{tabular}

To preserve the integrity of subcellular organelles, cells were disrupted gently by sequential pushing them through injection needles of decreasing diameter: 22-, 24- and $27-\mathrm{G} x$. Cell homogenate was centrifugated for $10 \mathrm{~min} 3,000 \mathrm{x}$ g at $4^{0} \mathrm{C}$ and postnuclear 
supernatant (PNS) was collected. Then PNS was separated on a Nycodenz step gradient: $1 \mathrm{ml}$ of each : 40, 30, 25, 15, 12.5, 10, 7,5, 5, and 2.5\% (v/v) Nycodenz in internal medium. After centrifugation at $120,000 \times \mathrm{g}_{\mathrm{av}}$ for $1 \mathrm{~h}$ at $4{ }^{\circ} \mathrm{C}$ in a SW 40.1 rotor 9 fractions ( +1 bottom fraction) were collected from the top and analysed for total protein concentration. The gradient fractions were diluted with internal medium and spun again for $2 \mathrm{~h}$ at $100,000 \mathrm{x} \mathrm{g}_{\text {av }}$ to separate membranes and soluble proteins in each fraction. The pellets obtained from each fraction were dissolved in "internal medium" in the presence of 1\% Triton X-100 and were used for immunoblotting and immunoprecipitation.

Biotinylated fractions (indicating an enrichment of plasma membrane) were detected after transfer to PVDF membranes with streptavidin-peroxidase. Golgi fractions were detected by immunoblotting with anti-ERD2 antibodies. ER fractions were detected by immunoblotting with anti-KDEL antibodies.

\subsection{Immunoprecipitation}

Plasma membrane and Golgi membrane fractions were obtained from the gradient centrifugation. Fractions were dissolved in the internal medium in the presens of $1 \%$ Triton $\mathrm{X}-100$, then fractions were precleared by incubation with $50 \mu$ protein $\mathrm{A}$ Sepharose for $1 \mathrm{~h}$ at $4^{\circ} \mathrm{C}$ under rotation. Precleared fractions were incubated with $5 \mu \mathrm{l}$ anti-Cx43 antibodies, developed against the first extracellular loop ( $\left.\mathrm{aa}_{46}-\mathrm{aa}_{68}\right)$ for $2 \mathrm{~h}$ at $4^{\circ} \mathrm{C}$ on a rotating platform, and then with $100 \mu$ Protein-A-Sepharose under the same conditions.

After washing, samples were boiled for 2 min in $50 \mu 1$ 2x SDS-PAGE sample buffer. The liquid phases were collected and 12\% SDS-PAGE was carried out.

\subsection{Denaturating polyacrylamide gel electrophoresis (SDS-PAGE)}

The detergent sodium dodecyl sulphate binds to proteins at an average of one SDS molecule per two amino acid residues. SDS denaturates the proteins, dissociates protein complexes and imparts the negative charge of polypeptide chains. Reducing agents such as dithiothreitol (DTT) or 2-mercaptoethanol are used to reduce cystines (disulphide bonds). The electrophoretic mobility of SDS-protein complexes is inversely proportional to the logarithm of the molecular mass of the protein. 
Solutions:

Stacking gel buffer:

Tris/HCl $0.5 \mathrm{M}$

In $\mathrm{H}_{2} \mathrm{O}$ bidest., pH 6.8

$\underline{\text { Resolving gel buffer: }}$

Tris/HCl 1,5 M

SDS $0.4 \%(\mathrm{w} / \mathrm{v})$

In $\mathrm{H}_{2} \mathrm{O}$ bidest., $\mathrm{pH} 8,6$

APS : Ammoniumpersulphate $40 \%(\mathrm{w} / \mathrm{v})$ in $\mathrm{H}_{2} \mathrm{O}$ bidest

SDS: $10 \%(\mathrm{w} / \mathrm{v})$ in $\mathrm{H}_{2} \mathrm{O}$ bidest

TEMED: $60 \%(\mathrm{w} / \mathrm{v})$

Running buffer:

Tris base $25 \mathrm{mM}$

Glycin 190mM

SDS $\quad 0.1 \%(\mathrm{w} / \mathrm{v})$

\begin{tabular}{|l|l|l|}
\hline & $12 \%$ resolving gel & $5 \%$ Stacking gel \\
\hline $\mathrm{H}_{2} \mathrm{O}$ & $5 \mathrm{ml}$ & $4.7 \mathrm{ml}$ \\
\hline Resolving gel buffer & $3.75 \mathrm{ml}$ & - \\
\hline Stacking gel buffer & - & $3.4 \mathrm{ml}$ \\
\hline Acrylamide+bisacrylamide $30 \%$ & $6 \mathrm{ml}$ & $1.4 \mathrm{ml}$ \\
\hline SDS10\% & $150 \mu \mathrm{l}$ & $100 \mu \mathrm{l}$ \\
\hline APS40\% & $37.5 \mu \mathrm{l}$ & $37.5 \mu \mathrm{l}$ \\
\hline TEMED & $15 \mu \mathrm{l}$ & $10 \mu \mathrm{l}$ \\
\hline
\end{tabular}

Tab.2 Preparation of 12\% resolving and 5\% stacking gels for SDS-PAGE. 
Solutions for resolving gel were mixed according to the Tab.2 and poured immediately after addition of TEMED and APS, up to $2 \mathrm{~cm}$ from the top of the gel cassette. A few drops of isopropanol were added to prevent desiccation of the gel. After polymerisation isopropanol was rinsed off and a freshly prepared stacking gel solution added. Slots where formed by placing of the comb. Gel cassette was transferred to the electrophoresis chamber (BioRad) with running buffer; markers and protein samples were inserted into the hollows. A constant $25 \mathrm{~mA}$ current was applied untill the bands reached the bottom of the gel.

\subsection{Staining of proteins at the SDS-PAGE}

Gels were stained in Coomassie blue staining solution for 2 hour at room temperature followed by reduction of the background using destaining solution 1 for several hours at room temperature. Gels were rehydrated by equilibration in destaining solution 2 .

\section{Staining solution:}

Coomassie brilliant blue R250 $2 \mathrm{~g}$

Coomassie brilliant blue G1 $0.5 \mathrm{~g}$

Ethanol $425 \mathrm{ml}$

Methanol $50 \mathrm{ml}$

Acetic acid $100 \mathrm{ml}$

$\mathrm{H}_{2} \mathrm{O}$ bidest. $425 \mathrm{ml}$

\section{Destaining solution 1:}

Ethanol $450 \mathrm{ml}$

Acetic acid $100 \mathrm{ml}$

$\mathrm{H}_{2} \mathrm{O}$ bidest $450 \mathrm{ml}$

Destaining solution2:

Acetic acid $70 \mathrm{ml}$

$\mathrm{H}_{2} \mathrm{O}$ bidest. $930 \mathrm{ml}$ 


\subsection{Immunoblotting}

\subsubsection{Western blotting onto nitrocellulose membranes}

After completion of electrophoresis the polyacrylamide gel was removed and placed on top of two sheets of Whatman filter paper and a nitro-cellulose membrane $(0.2 \mu \mathrm{m}$ pore diameter) pre-equilibrated in blot buffer. After carefully removing of air bubbles, other two sheets of Whatman filter paper pre-equilibrated with blot buffer, were applied on top. The transfer sandwich was set up on the cathode plate of the chamber in the corresponding position and covered with a lid comprising the anode. For an 8x6x0.1 cm gel, transfer was carried out at $100 \mathrm{~mA}$ constant current for 1 hour.

Blot buffer:

$25 \mathrm{mM}$ Tris/HCl, $\mathrm{pH} 8.3$

$192 \mathrm{mM}$ glycine

$20 \%(\mathrm{w} / \mathrm{v})$ methanol

\subsubsection{Western blotting onto PVDF membranes}

Immobilon-P PVDF (polyvinylidene difluoride) membranes (Millipore) were used. The transfer sandwich was composed of:

1. Whatman filter paper equilibrated for a few minutes in anode buffer 1;

2. Whatman filter paper equilibrated for a few minutes in anode buffer2;

3. PVDF membrane activated for a few seconds in methanol, washed for

2-3 min in double-distilled water and equilibrated for $5 \mathrm{~min}$ in anode buffer 2;

4. Separating gel equilibrated for 5 minutes in cathode buffer;

5. Whatman filter paper equilibrated for a few minutes in cathode buffer.

Transfer was carried out as for nitrocellulose blots.

\section{Anode buffer 1:}

0.3M Tris/HCl, $\mathrm{pH} 10.4$ at $\mathrm{RT}$

$20 \%(\mathrm{v} / \mathrm{v})$ methanol 
Anode buffer2:

$25 \mathrm{mM}$ Tris/HCl, $\mathrm{pH} 10.4$ at RT

$20 \%(\mathrm{v} / \mathrm{v})$ methanol

Cathode buffer:

25 mM Tris/HCl, pH 9.4

$20 \%(\mathrm{v} / \mathrm{v})$ methanol

\subsubsection{Immuno-staining of Western blots}

Blocking solution:

$0.1 \%$ Tween

$1 \%$ low fat milk in PBS

Washing solution:

$0.1 \%$ Tween in PBS

The blotted membranes were washed with blocking solution for $1 \mathrm{~h}$ at RT to saturate unspecific protein binding sites on the membrane and then incubated with primary antibodies (generally at 1:5000 dilution) in $10 \mathrm{ml}$ of the fresh blocking buffer for $1 \mathrm{~h}$ at RT. After 3 times washes (20 min each) with washing solution the membranes were incubated with horseradish peroxidase coupled secondary antibodies (goat anti-rabbit or goat anti-mouse, diluted 1: 2000 in $10 \mathrm{ml}$ of the fresh blocking buffer) for $1 \mathrm{~h}$ at RT. Then membranes were washed again 3 times (20 min each) with washing solution and 3 times with PBS.

\subsubsection{Chemiluminescence}

Detection by chemiluminescence was performed using the Super Signal Substrate kit (Pierce) as recommended by the manufacturer. The method utilises a peroxide solution as substrate for horseradish peroxidase and a Luminol/enchancer solution for amplification of the signal. The signal was recorded by Fujifilm LAS-1000 cooled CCD camera and analysed using Aida image analysis software (Fuji). 


\subsection{Protein sequencing}

Protein bands, obtained from pool down assay were excised from the gels. Each band was digested with trypsin and sequenced utilising MALDI Q-TOF mass spectrometry by Dr. Kathryn Lilley (Proteomics Center, Cambridge).

\subsection{Mammalian cell culture techniques}

\subsubsection{Cell culture}

Vero cells, COS cells and mouse astrocytes were cultivated in DMEM supplemented with $10 \%$ FCS, $100 \mathrm{U} / \mathrm{ml}$ penicillin, $0.1 \mathrm{mg} / \mathrm{ml}$ streptomycin, $100 \mathrm{mM}$ L-glutamine, 100 $\mathrm{mM}$ sodium pyruvate. Cells were grown at $37^{\circ} \mathrm{C}$ under $5 \% \mathrm{CO}_{2}$ and $95 \%$ humidity. Vero cells were stored at $-170^{\circ} \mathrm{C}$ under liquid nitrogen in $10 \%$ DMSO in DMEM containing $20 \%$ FCS. Vero cells were used not more than 20 first passages. Mouse astrocytes were used as primary culture not more than 4 passages.

\subsection{2 cDNA transfection of cultured cells by electroporation}

Transfection buffer ("cytomix"):

$\mathrm{KCl} 120 \mathrm{mM}$

$\mathrm{KH}_{2} \mathrm{PO}_{4} 10 \mathrm{mM}$

EGTA $2 \mathrm{mM}$

$\mathrm{MgCl}_{2} 5 \mathrm{mM}$

Hepes $25 \mathrm{mM}$

$\mathrm{CaCl}_{2} 0.15 \mathrm{mM}$

GSSG $5 \mathrm{mM}$

ATP $2 \mathrm{mM}$

Cells were grown in $14 \mathrm{~cm}$ Petri dishes to $80 \%$ confluence, washed twice with PBS, detached by trypsin treatment, resuspended in $10 \mathrm{ml} \mathrm{PBS}$ and centrifuged at 1,000 rpm for $3 \mathrm{~min}$. Cell pellets were resuspended in $1 \mathrm{ml}$ transfection buffer. $350 \mu \mathrm{l}$ of cell suspension was transferred to $0.2 \mathrm{~cm}$ electroporation cuvette together with $15 \mu \mathrm{g}$ of 
cDNA. The cuvette was placed into a Gene Pulse electroporator (BioRad) and pulsed once with $0.7 \mathrm{kV}, 50 \mu \mathrm{F}$, and 200 Ohms. The time constant was usually about $1.4 \mathrm{~ms}$. 15-20 min after transfection cells were resuspended in the medium and plated again. The expression of plasmid-coded proteins was examined 6-24 $\mathrm{h}$ after tranfection.

\subsection{3 cDNA transfection using Lipofectamine 2000}

Astrocytes where transfected in the presence of Lipofectamine 2000. For transfection $50 \mu \mathrm{l}$ of Optimem containing $1 \mu \mathrm{g}$ of DNA were mixed with $50 \mu \mathrm{l}$ of Optimem containing $2 \mu \mathrm{l}$ of Lipofectamine 2000 and added 20 min after mixing to cells growing on one cover slip (diameter $12 \mathrm{~mm}$ ). Then cells were incubated at $37^{\circ} \mathrm{C}$ under $5 \% \mathrm{CO}_{2}$ and $95 \%$ humidity. After 4-5 hours DMEM medium was exchanged for DMEM without Lipofectamine 2000. Protein expression was examined 12-24 h after transfection.

\subsection{4 si-RNA transfection}

RNA interference (si-RNA) is a highly conserved gene silencing mechanism that uses double-stranded RNA (dsRNA) as a signal to trigger the degradation of homologous mRNA. si-RNA oligos directed against Drebrin mRNA

(5'CCAGAAGGUGAUGUACGGCdTdT 3' sense and 3'dTdTGGUCUU

CCACUACAUGCCG 5'antisense) nonlabeled or labelled with Cy3 at the 5'sense end were produced by Dharmacon (www.Dharmacon com.).

Oligofectamine reagent (Invitrogen) was used for si-RNA transfection according to the manufacturer's instruction. For one well $\mathrm{d}=24-30 \mathrm{~mm} 20 \mu \mathrm{l}$ of Oligofectamine and $20 \mu \mathrm{l}$ of $20 \mu \mathrm{M}$ si-RNA was taken. For co-transfection of si-RNA and DNA, cells were electroporated as described earlier except that the buffer was prepared with deionised RNase-free water. Expression patterns were analysed by immunofluorescence, western blotting, dye transfer and electrophysiology 10, 24,and 48 hours after transfection.

\subsection{Indirect immunofluorescence}

Blocking solution: $0.1 \%$ saponin in PBS

Permeabilizing solution: $0.1 \%$ saponin/3\% BSA in PBS. 
Cover slips with cells grown to about $80 \%$ confluency, were transferred to 24 well plates, washed 3 times with PBS, and fixed with $4 \%$ paraformaldehyde in PBS for 15 min at RT. The fixed cells were treated for $10 \mathrm{~min}$ with $50 \mathrm{mM} \mathrm{NH}_{4} \mathrm{Cl}$ to inactivate free aldehyde groups, and washed twice with PBS. Cells were then incubated in blocking solution for $10 \mathrm{~min}$ at $37^{\circ} \mathrm{C}$ and subsequently in permeabilising solution for $10 \mathrm{~min}$ at $37^{\circ} \mathrm{C}$. Incubation with primary antibodies was carried out in a humidity chamber at $37^{\circ} \mathrm{C}$ for $1 \mathrm{~h}$ at a dilution of 1:100. Thereafter cells were sequentially washed with permeabilizing solution, blocking solution, and PBS. Incubation with Cy3- (or Cy2-) labeled secondary antibodies was performed under the same conditions. After washing cells were mounted with Dako fluorescence mounting medium and analysed by fluorescence microscopy.

\subsection{Fluorescence- and immunofluorescence microscopy and image processing}

Fluorescence microscopy was performed with Zeiss LSM410 fluorescence microscope equipped with 100x 1.4 NA oil immersion Plan Achromate objective, a CCD-camera (Kodak, Princeton Instruments Inc.)

Filter set was:

GFP and Cy2: excitation BP 470/20, emission BP 505/530;

Cy3: excitation BP 546/2, emission BP 575-640;

CFP: excitation BP 430/20, emission BP 485/17;

YFP: excitation BP 500/20, emission BP 535/30.

Acquired images were documented and analyzed using MetaMorph 6.0 (Universal Imaging Corporation, West Chester, PA) and Adobe Photoshop 5.0.

\subsection{FRET analysis}

CFP-Drebrin (donor) and Cx43-YFP (acceptor) were co-expressed in Vero cells for 12 h. FRET was estimated from the increase of donor fluorescence after acceptor bleaching. Images of $\mathrm{Dbb}$ (donor fluorescence before bleach) and $\mathrm{Abb}$ (acceptor fluorescence before bleach) were acquired with a Zeiss Axiovert 100 TV fluorescence microscope equipped 
with 100x 1.4 NA oil immersion Plan Achromate objective, a CCD-camera (Kodak, Princeton Instruments Inc.), and CFP and YFP filter sets (Omega Optics and AF Analytic, Germany). An increase in donor fluorescence was monitored with the excitation filter set contained for excitation: BP 430/20, for emission: BP 485/17. The acceptor was photoinactivated using an Ar-Kr-ion laser (INNOVA 70C Spectrum, Coherent) laser $\lambda=530 \mathrm{~nm}$. After bleaching two images: Dab (donor fluorescence after bleaching) and Aab (acceptor fluorescence after bleaching) were recorded. The wavelength $\lambda=530 \mathrm{~nm}$ ensured that CFP (max.excitation: $\lambda=440 \mathrm{~nm}$ ) was bleached only negligibly while more than $95 \%$ of the YFP (max.excitation: $\lambda=515 \mathrm{~nm}$ ) was bleached within 3 min. Images were analysed with the MetaMorph 6.0 program (Universal Imaging Corporation, West Chester, PA). Intensity of fluorescence of a CFPdrebrin (donor) and Cx43-YFP (acceptor) before and after bleaching was shown using the linescan and 3D-profilescan trough the region of cell-cell contact. As a negative control the unchanged background region was depicted before and after the acceptor bleaching.

\subsection{Electron microscopy of ultrathin cryo-sections}

Electron microscopy of ultrathin cryo-sections was kindly performed by Dr. Dirk Wenzel, Max-Plank- Institute of Biophysical Chemistry, Goettingen, Germany. Shortly, Vero cells were co-transfected with Cx43-YFP and CFP-drebrin or si-RNA against Drebrin. For immunolabeling, ultrathin cryo-sections were incubated with antiCx43 or anti-drebrin antibodies for $1 \mathrm{~h}$ followed by a 30 min incubation with 10 or $5 \mathrm{~nm}$ colloidal gold-labeled goat-anti-rabbit or goat anti-mouse Fabs (British BioCell). Immunolabeled sections were examined with a Phillips CM120 electron microscope.

\subsection{Microinjection}

Calcein (1\% in "Cytomix" solution) was microinjected using an Eppendorf microinjection system. Dye transfer was examined, using an inverse fluorescence microscope (IM35, Zeiss, Oberkochen, Germany) with filter set for excitation $\lambda=494$ $\mathrm{nm}$, for emission $\lambda=517 \mathrm{~nm}$. 


\subsection{Electrical coupling analysis using double patch clamp in whole cell configuration}

Coverslips with adherent cells were transferred from the culture dishes to the experimental chamber under an upright microscope (Axioskop, Zeiss) with phasecontrast optics, fitted with $2.5 \mathrm{x}$ plan/0.075 numerical aperture and $40 \mathrm{x}-\mathrm{W} / 0.80$ objectives. The chamber was superfused with Krebs-Ringer solution.

Krebs-Ringer solution:

$\mathrm{NaCl} 140 \mathrm{mM}$

$\mathrm{KCl} 4 \mathrm{mM}$

$\mathrm{CaCl}_{2} 2 \mathrm{mM}$

$\mathrm{MgCl}_{2} 1 \mathrm{mM}$

glucose $5 \mathrm{mM}$

pyruvate $2 \mathrm{mM}$

HEPES $5 \mathrm{mM}$, pH 7.4 at RT

Patch pipettes were fabricated from borosilicate glass filaments (BioMedical Instruments) by means of a horizontal puller (DMZ-Universal, Zeiss-Instrument, München, Germany). When filled with electrode solution, the pipettes had a DC resistance of 2-5 MOhm.

Pipette solution:

$\mathrm{KCl} 140 \mathrm{mM}$

sodium aspartate $10 \mathrm{mM}$

MgATP 3 mM

$\mathrm{MgCl}_{2} 1 \mathrm{mM}$

$\mathrm{CaCl}_{2} 1,4 \mathrm{mM}$

EGTA 5 mM (pCa 7.5)

HEPES $5 \mathrm{mM}$

In $\mathrm{H}_{2} \mathrm{O}$ bidest., $\mathrm{pH} 7.2$, filtered through $0.22-\mu \mathrm{m}$ filters. 
Experiments were carried out on pairs of cells using the dual voltage-clamp method in the whole-cell configuration. Electrodes were connected to separate clamp amplifiers EPC7 (ESF, Friedland) and EPC9 (HEKA Electronics, Lambrecht, Germany). Initially, the membrane potential of both cells was clamped to $-70 \mathrm{mV}$. Voltage steps of $10 \mathrm{mV}$ (from $-160 \mathrm{mV}$ to $+170 \mathrm{mV}$ ) were applied to cell 1 while cell 2 was kept at $-70 \mathrm{mV}$. Current responses from both cells were recorded. Recordings were filtered at $3 \mathrm{kHz}$ and digitized at $10 \mathrm{kHz}$, using the program PULSE, version 8.53 (HEKA Electronics, Lambrecht, Germany, EPC9) or Axograph 4.6 (Axon Instruments, USA, EPC7) and stored on the hard disks of two Macintosh computers for off-line analysis (Igor Pro). The coupling ratio between contacting cells was calculated as relation of current in cell 2 to current in cell $1\left(\mathrm{I}_{2} / \mathrm{I}_{1}\right)$. 


\section{Results}

\subsection{Intracellular transport of connexin 43}

Connexins are relatively short living molecules (half-live 1-3h; Musil et al., 1990), which are co-translationally inserted into the endoplasmic reticulum (ER) membrane. Six connexin molecules oligomerise to form a connexon in the ER membrane. Connexons are transported through the Golgi network to the plasma membrane, where docking to connexons from neighbouring cells forms gap junctions. To investigate the transport of connexin43 from the ER to the plasma membrane, the Cx43 fused to green (Cx43-GFP), yellow (Cx43-YFP) or cyan (Cx43-CFP) fluorescent protein was expressed in Vero cells (Fig.5). ER-Golgi localisation of Cx43 fused to fluorescent protein was usually detected $4-5 \mathrm{~h}$ after transfection by electroporation (Fig.5 a), formation of gap junctional plaques was observed 6-10 h after transfection (Fig.5 b).
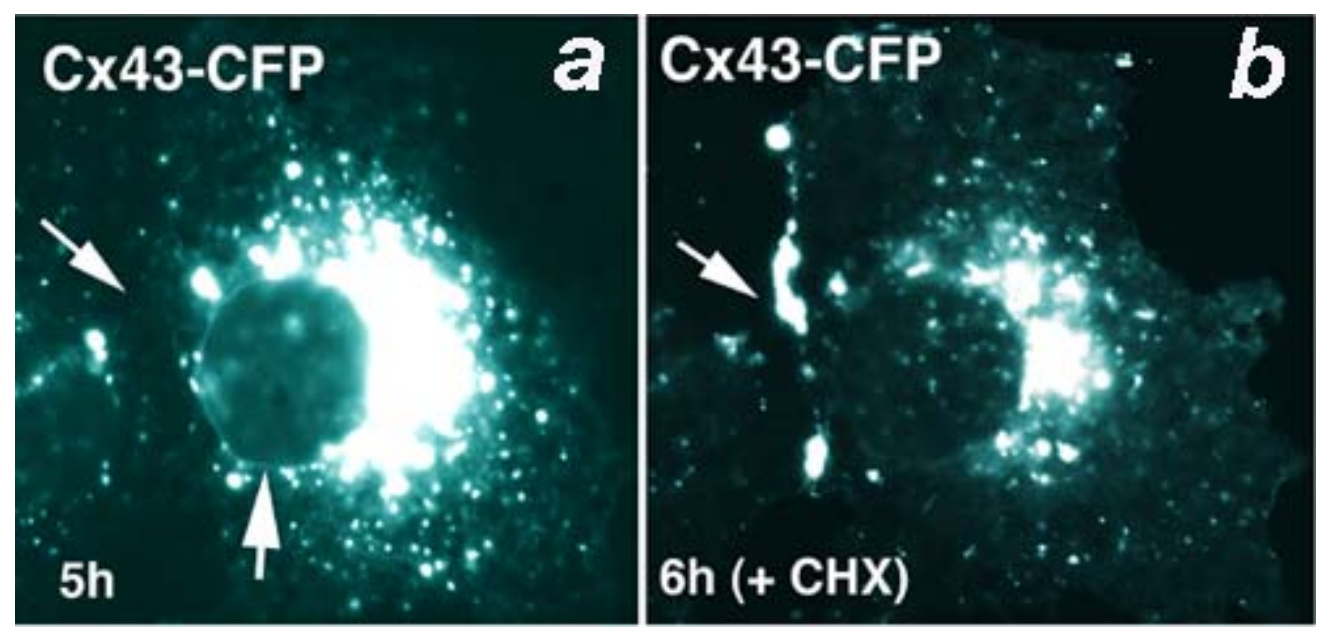

Fig.5 Intracellular transport of connexin43-CFP

a): Localisation of Cx43-CFP in the endoplasmic reticulum (ER) and Golgi region $5 \mathrm{~h}$ after transfection (arrows indicate presence of $\mathrm{Cx} 43-\mathrm{GFP}$ in the ER and absence at the contacting plasma membrane) .

b): Localisation of $\mathrm{Cx} 43-\mathrm{CFP}$ in the Golgi and formation of gap junctions between contacting cells (arrow) $6 \mathrm{~h}$ after transfection. Cycloheximide (CHX) was added to block new protein synthesis $5 \mathrm{~h}$ after transfection.

\subsection{Involvement of small GTPases in the transport of connexin 43}

Small GTPases are involved in the formation of transport vesicles on the surface of either the ER, the Golgi complex, or endosomes. The small GTPase Sar1 is responsible for the initiation of COPII-dependent transport of vesicles from the ER membrane (Aridor et al., 
2001). The small GTPase ARF-1 (ADP-ribosylation factor) regulates the formation of COPI coated secretory vesicles from the Golgi network (Pepperkok et al., 1998; Spang et al., 2002). Involvement of small GTPases in the transport of connexin43 was analysed. Experimental data revealed that overexpression of the GTP-restricted mutant of Sar1p in Vero cells blocked transport of connexin43 from the ER to the Golgi (Fig.6). Moreover, Cx43 accumulated in the ER release sites, colocalising with Sec13 (Fig.7). Sec 13 is a protein of the COPII complex, which initiates membrane deformation and vesicle budding, and a marker of ER-release sites (Hobman et al., 1998; Tang et al., 2001).

The GTP-bound form of ARF1 (ARF1Q71L) blocked exit of Cx43 from the Golgi, preventing its appearance on the plasma membrane (Fig.8).
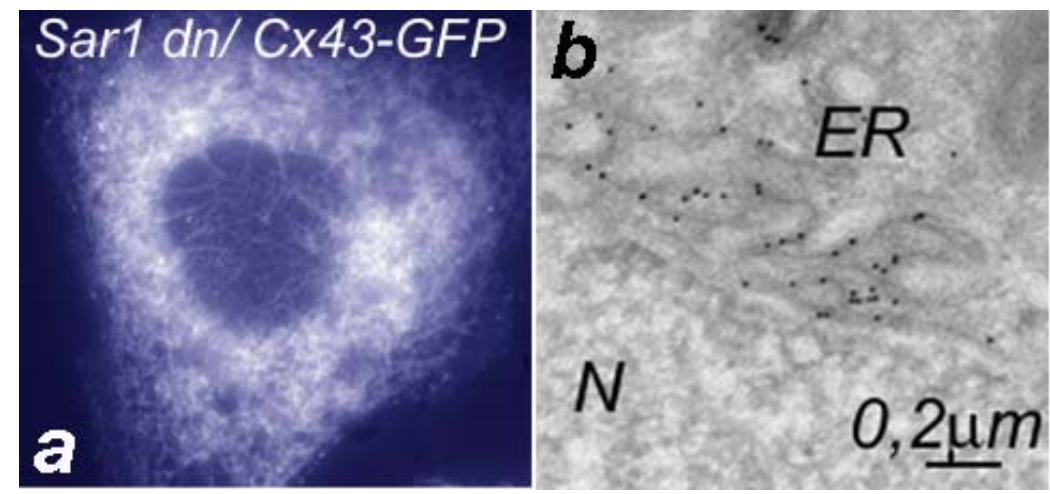

Fig.6 a): Expression of Sar1 dn prevents exit of Cx43-GFP from the endoplasmic reticulum. In Vero cells coexpressing Sar $1 \mathrm{dn}$ and Cx43-GFP (10 h after transfection) Cx43-GFP was present only in the ER. In control Vero cells, transfected with Cx43-GFP plasmid only, Cx43GFP was present in the Golgi and at the plasma membrane, like in Fig.5, b.

b): Immuno-electron microscopy image of a Vero cell, coexpressing Sar $1 \mathrm{dn}$ and Cx43-GFP. Accumulation of Cx43-GFP in ER membranes was detected with anti-Cx43 antibodies.

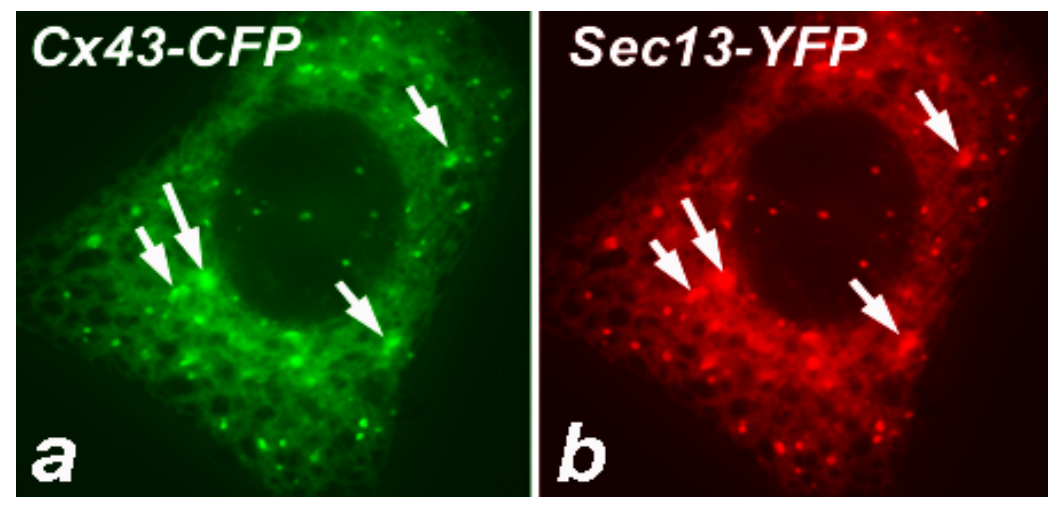

Fig.7 Cx43-CFP accumulates in ER- release sites in Sar1 dn expressing Vero cells (12 h after transfection) as indicated by colocalisation with Sec13 (arrows). 

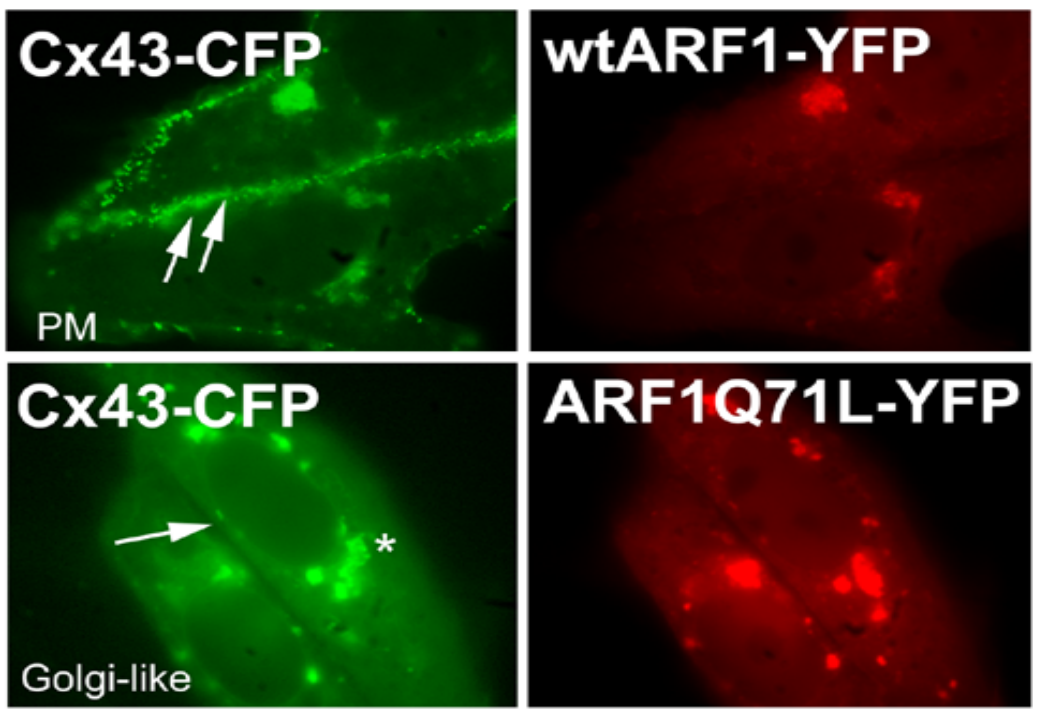

Fig. 8 Vero cells, co-expressing Cx43-CFP and wild type or mutant ARF1-YFP (12 h after transfection). Overexpression of wild type ARF1 does not affect the transport of Cx43-CFP from the Golgi to the PM (upper panel). Overexpression of ARF1 Q71L blocks exit of Cx43CFP from the Golgi and prevents appearance of gap junctions on the plasma membrane (lower panel).

\subsection{Pull down assay with GST-CT-Cx43, protein sequencing and identification of drebrin as a $\mathrm{Cx} 43$-interacting protein}

In search for new interaction partners of $\mathrm{Cx} 43$ we used a proteomics approach to screen subcellular fractions from different mouse tissues (brain, kidney, lung, heart, liver) for proteins that may interact with a GST-fusion protein encompassing the $\mathrm{COOH}$-terminal domain of $\mathrm{Cx} 43$ (residues 234-382), which is normally exposed to the cytosol. Pull-down assays using this $\mathrm{Cx} 43-\mathrm{COOH}$ terminal domain GST-fusion protein recovered several bands that were resolved by SDS-PAGE and visualised with Coomassie Blue (Fig.9). MALDI/ Q-TOF (matrix assisted laser desorption ionisation/ quadripole time of flight) mass spectrometry analysis of tryptic peptides identified a number of candidate interacting proteins. One of them, drebrin E, was reproducibly recovered in pull-down assays from brains membrane fractions using the Cx43GST fusion protein. Together, 22 peptides with exact matches to the cDNA-derived protein sequence of drebrin were obtained by Q-TOF sequence analysis (Tab.3). 


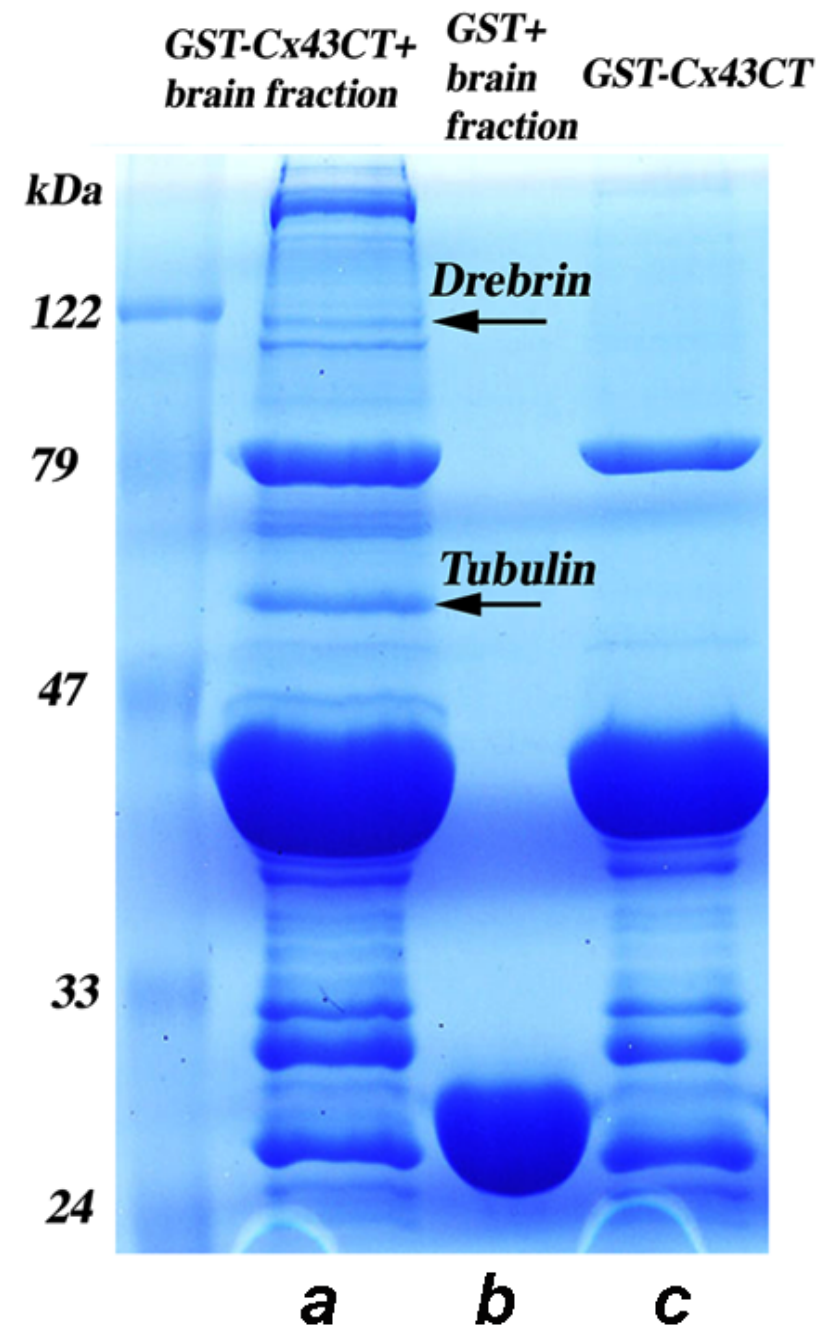

Fig.9 Result of pull down experiment using the GST-Cx43-C-terminal construct (aa 234- $\mathrm{aa}_{382}$ ) and a membrane fraction of mouse brain homogenate. SDS-PAGE: a) pull down with GST-Cx43-C-terminal construct and a membrane fraction of mouse brain homogenate; b) control pull down with GST alone and a membrane fraction of mouse brain homogenate; c) GST-Cx43-C-terminal construct. Arrows indicate position of drebrin and $\beta$-tubulin in the pulled down fraction. 


\begin{tabular}{|l|l|l|l|}
\hline Nr. & matched peptide & $\begin{array}{l}\text { amino acid number } \\
\text { in drebrin sequence }\end{array}$ & score \\
\hline 1 & DSQAALPK & $72-78$ & 18 \\
2 & MAPTPIPTR & $330-338$ & 55 \\
3 & EQFWEQAK & $178-185$ & 40 \\
4 & EQSIFGDQR & $53-61$ & 76 \\
5 & VMYGFCSVK & $63-71$ & 14 \\
6 & DEEEESQMK & $262-270$ & 13 \\
7 & QQSLEAEEAK & $239-248$ & 101 \\
8 & LELLAAYEEV & $11-20$ & 100 \\
9 & YVLINWVGED & $80-89$ & 92 \\
10 & LREDENAEPV & $50-59$ & 26 \\
11 & SPSDSSTAST & $339-348$ & 63 \\
12 & LAASGEGGLQ & $43-52$ & 32 \\
13 & SESEVEEAAA & $272-281$ & 44 \\
14 & EESAADWALY & $23-32$ & 49 \\
15 & KSESEVEAA & $271-280$ & 20 \\
16 & ALDEVTSSQP & $57-66$ & 14 \\
17 & LELLAAYEEVIR & $11-22$ & 115 \\
18 & EDENAEPVGTTYQK & $152-165$ & 75 \\
19 & LREDENAEPVGTTYQK & $150-165$ & 18 \\
20 & LAASGEGGLQELSGHFENQK & $43-62$ & 65 \\
21 & SESEVEEAAAIIAQRDNPR & $272-291$ & 37 \\
22 & ALDEVTSSQPPPPPPPPPPTQEAQE & $357-389$ & 145 \\
& TTPSLDEE & & \\
\hline
\end{tabular}

Tab.3 List of 22 peptides (total score: 1212) with exact matches to drebrin, which were obtained by MALDI Q-TOF MS from the band of $120 \mathrm{kDa}$ (see Fig.10).

(Score is $-10^{*} \log (\mathrm{P})$, were $\mathrm{P}$ is the probability that the observed match is a random event. Individual ions score $>50$ indicate identity or extensive homology $(\mathrm{p}<0,05))$. 


\subsection{Colocalization of drebrin and connexin 43 at cell-cell contacts}

Next the distribution of endogenous drebrin and connexin43 by immunofluorescence with corresponding antibodies was analysed. Immunofluorescence data from astrocytes and Vero cells clearly show that endogenous Cx43 is present at the Golgi region, non-contacting PM and at cell-cell contacts (Fig.10 a,b, Fig. 19 b). Endogenous drebrin is present inside the cells and at the PM. Intracellular drebrin localizes mostly along actin stress fibres in astrocytes (Fig.10c) and mostly at the Golgi region in Vero cells (Fig.19.a).

In astrocytes (Fig.10 b-d) and Vero cells (Fig.19 a,b) a clear colocalisation of both proteins underneath the plasma membrane in the regions of cell-cell contacts was observed. On the other hand, inside the cell and in non-contacting regions of the plasma membrane drebrin was not co-localised with Cx43 (Fig.10 d; Fig.19 a,b).

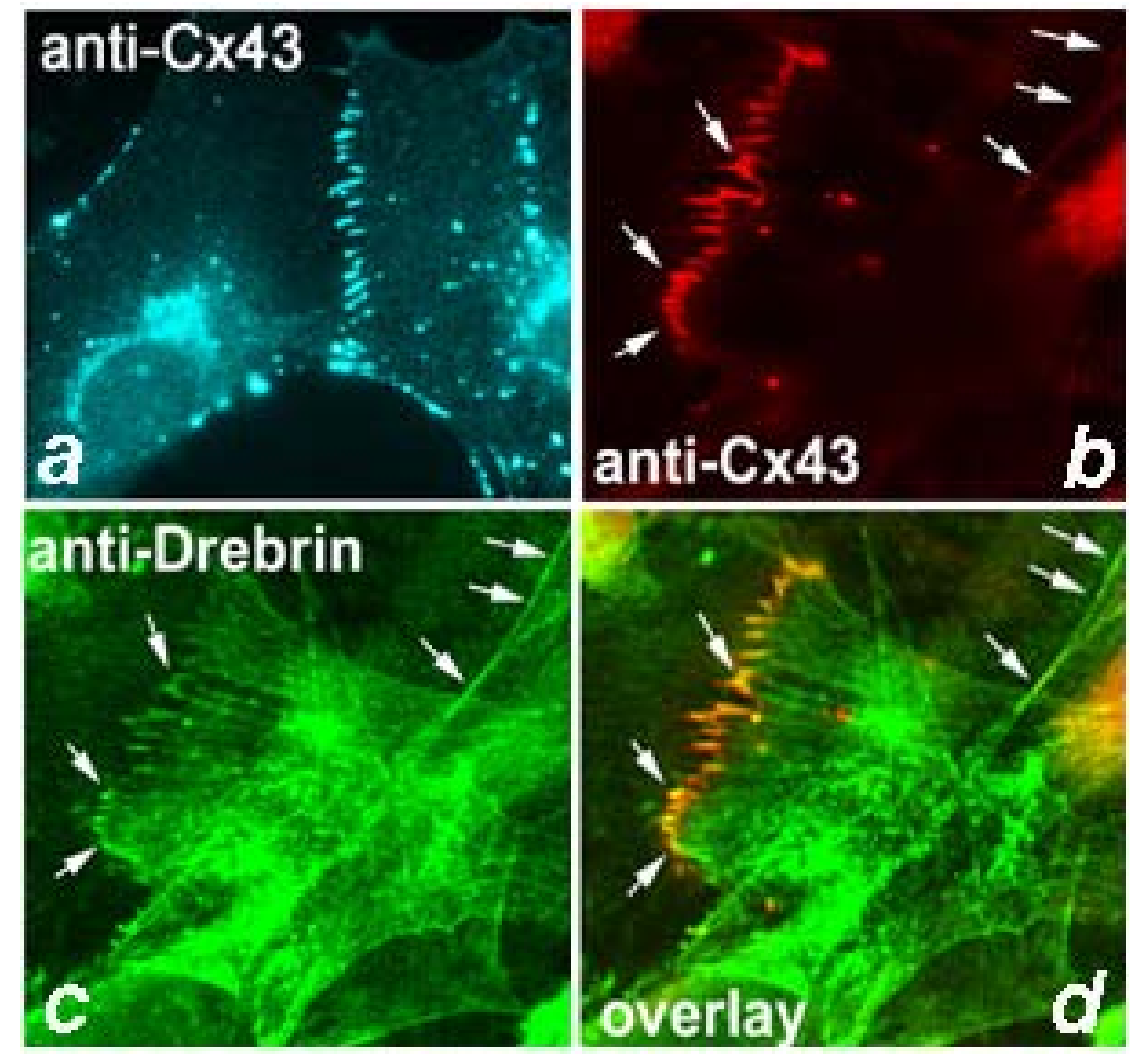

Fig.10 a): Distribution of endogenous connexin43 in mouse brain astrocytes $\mathrm{b}, \mathrm{c}, \mathrm{d})$ : Colocalisation of endogenous drebrin and connexin43 at cell-cell contact in astrocytes as detected with anti-Cx43 and anti-drebrin M2F6 antibodies respectively. 

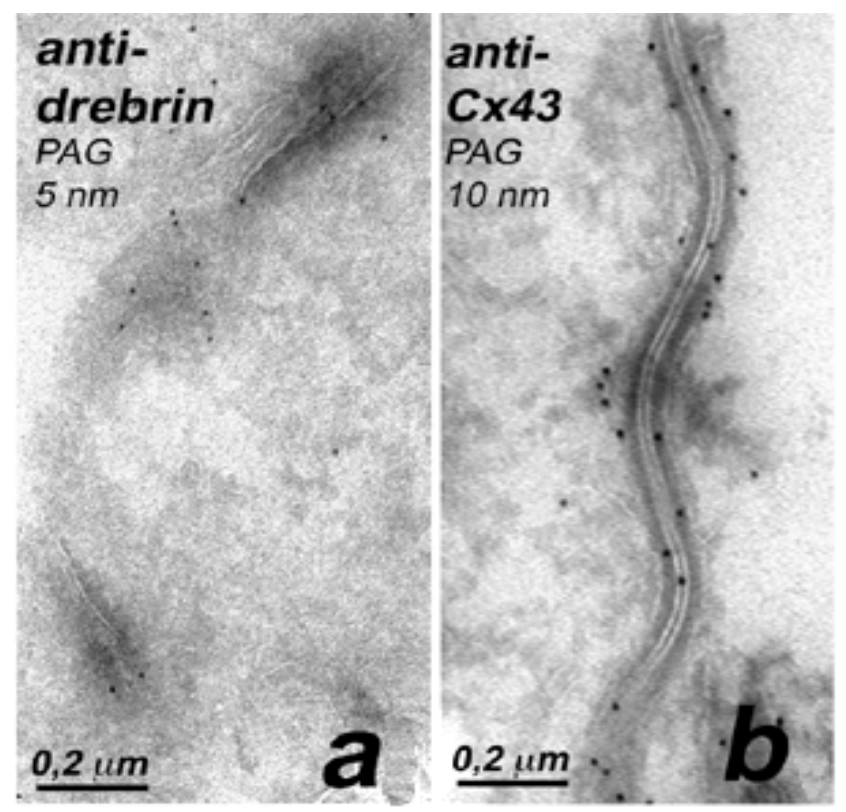

Fig.11 Distribution of CFP-drebrin (a) and Cx43-YFP (b) in Vero cells detected by immuno- electron microscopy. Note that in Vero cells (which have neither tight junctions, desmosomes or adherens junctions) drebrin is present in regions of cell-cell contact with a gap junction appearance.

\subsection{Drebrin and connexin 43 in subcellular fractions and immunoprecipitation using anti-Cx43 antibodies}

Subcellular fractionation was performed to analyse the intracellular distribution of connexin43 and drebrin E.

Biotinylated plasma membrane fractions were identified by their reaction with streptavidin (Fig.12 a,b). Golgi fractions were identified with anti-ERD2 antibodies. ER fractions were detected using anti-KDEL-sequence antibodies (Fig.12 b).

The pellets of the plasma membrane, Golgi and ER fractions were analysed for the presence of drebrin and connexin. Drebrin was detected in the pellet of the plasma membrane fraction, but not in the pellet of Golgi fraction using anti-drebrin antibodies (Fig.12 c). Connexin 43 was detected with anti-Cx 43 antibodies preferentially in the pellet of both plasma membrane and Golgi fractions (Fig.12 d).

Immunoprecepitations using anti-Cx43 antibodies, raised against the first extracellular loop (residues 46 - 68) were performed with the fractions, and co-precipitating proteins 
were analysed by immunoblotting with anti-drebrin antibodies. Drebrin was immunoprecipitated from the PM fraction (fraction1) but not from the Golgi fraction (fraction6) (Fig.12 e). These results confirm that drebrin is associated with $\mathrm{Cx} 43$ in the plasma membrane fraction.

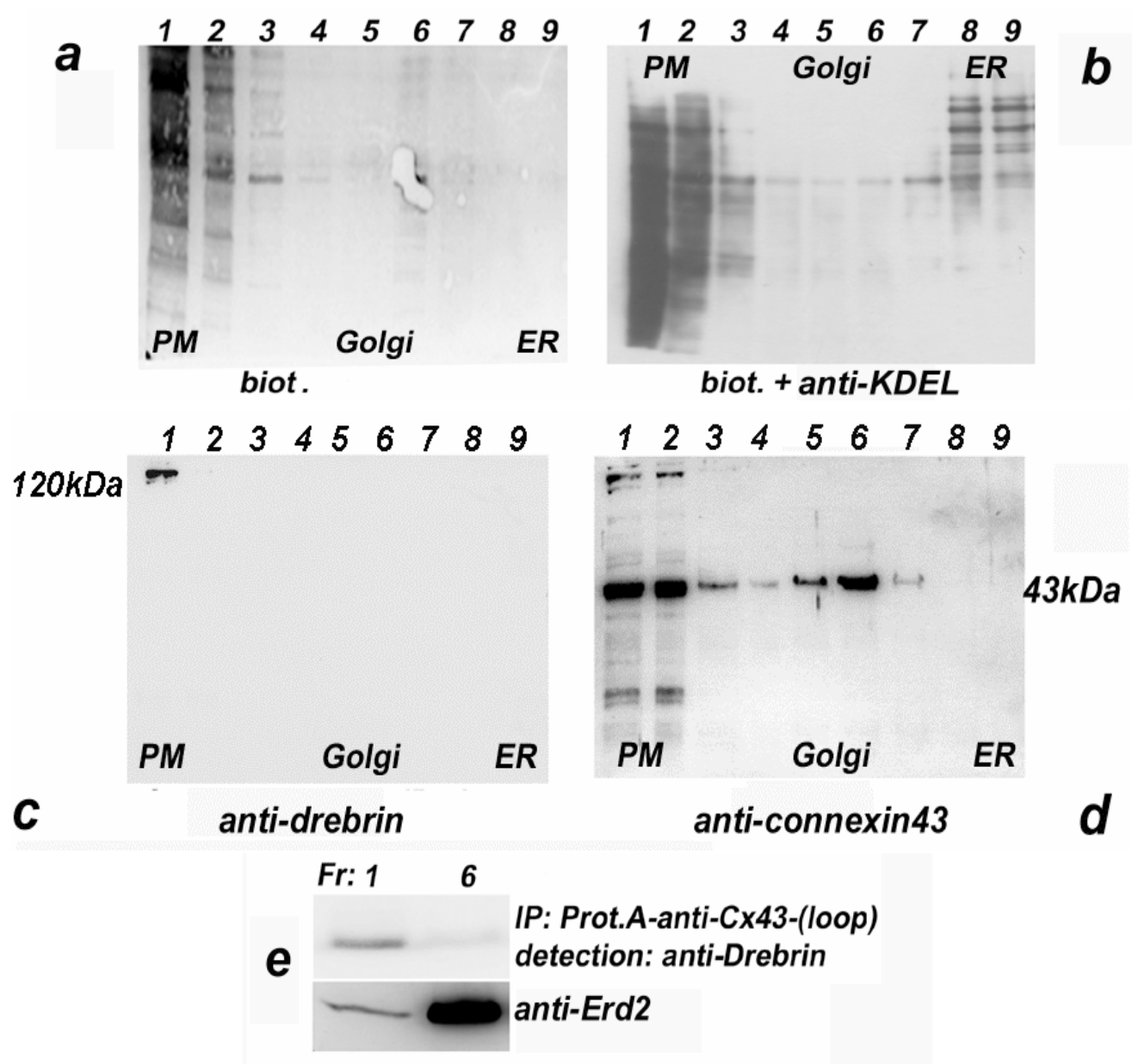

Fig. 12 Subcellular fractionation of Vero cells and characterisation of separated fractions. a): Fractions containing biotinylated proteins, corresponding to the plasma membrane (PM) were detected with streptavidin-peroxidase.

b): Blot probed with streptavidin-peroxidase (fractions 1-3) was again exposed to antiKDEL antibodies to reveal the endoplasmic reticulum (ER) proteins (fractions 8-9).

c): Drebrin was detected in the pellet of the plasma membrane fraction;

d): Connexin43 was present in the pellets of both plasma membrane and the Golgi fractions.

e): Anti-Cx43 antibodies immobilised on protein A sepharose can co-immunoprecipitate drebrin from the plasma membrane fraction (1) but not from the Golgi fraction (6). AntiERD2 antibodies (used as a control of the Golgi fractions) show the relative distribution of transmembrane Golgi protein in fractions 1 and 6. 


\subsection{Co-expression of fluorescent connexin43- and drebrin fusion}

\section{proteins in Vero cells}

Fluorescent fusion proteins of connexin43 and drebrin (CFP-drebrin and Cx43-YFP) were co-expressed in COS and Vero cells to investigate the intracellular distribution of these proteins. Live cell imaging revealed that drebrin is strongly accumulated in contacting regions of the plasma membrane only when $\mathrm{Cx} 43$ is present there (Fig.13; Fig.14 a,b; Fig.15 a-d).
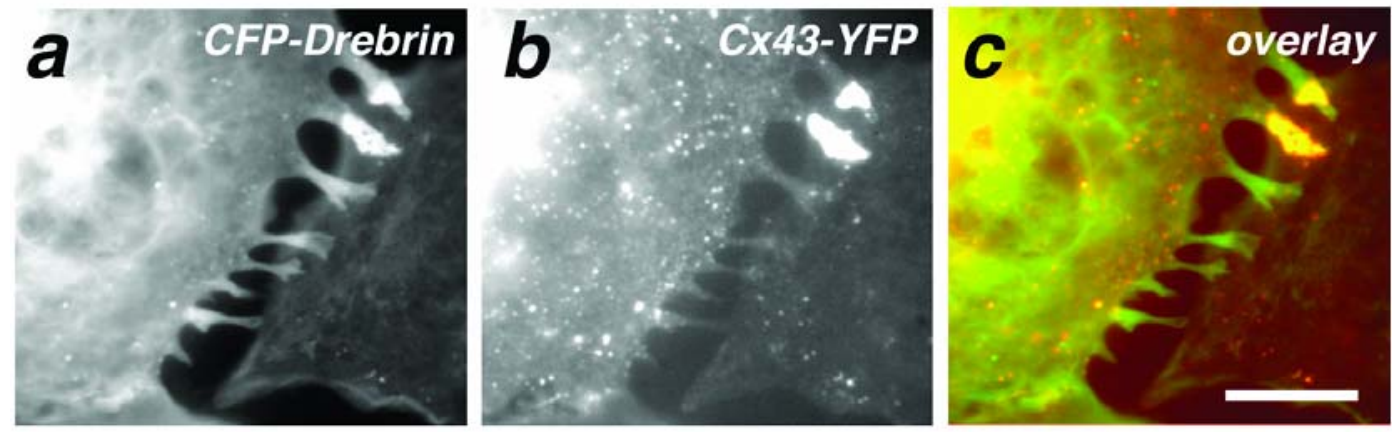

Fig.13 COS cells transfected with CFP-drebrin and Cx43-YFP plasmids reveal strong colocalisation of both proteins in the regions of cell-cell contacts. Note that overexpression of drebrin induces formation of processes (that was first described by Shirao et al., 1994), which form contacts with a neighbouring cell. Drebrin accumulates at zones of cell-cell contacts only if connexin 43 is present there.

\subsection{FRET analysis indicates CFP-drebrin/connexin43-YFP interaction in live Vero cells.}

To confirm the close proximity of drebrin and connexin 43 under the plasma membrane in the region of cell-cell contacts live cell fluorescence resonance energy transfer (FRET), using an acceptor bleach protocol (Majoul et al., 2001, 2002), was applied.

For these experiments CFP-drebrin and connexin43-YFP were expressed in Vero cells. In case of FRET proximity the photoinactivation of the acceptor (Cx43-YFP) results in an increase of the fluorescence of the donor (CFP-drebrin). First, donor and acceptor images were acquired as follows: donor before bleach (Dbb), and acceptor before bleach (Abb) (Fig14 a,b; Fig.15 a-d). Acceptor inactivation was 
performed in the region of cell-cell contact where both donor and acceptor were present, images were acquired as follows: acceptor after bleach (Aab) and donor after bleach (Dab) (Fig.14 c-d; Fig.15 e-f) and analysed using data processing (MetaMorph version 6.0 programm). The comparison of two graphs derived from the same cellular region obtained from the Dbb and Dab images revealed an increase of the donor fluorescence ranging from 15 to $25 \%$ (small arrows in zones of cell-cell contacts in (Fig.14 e; Fig.15 g). As a negative control the unchanged background region is depicted before and after the acceptor bleach (big arrows in Fig.14 e and Fig.15 g). The degree of acceptor photoinactivation in each pixel along the linescan is shown in Fig.14, e and Fig.15, g (Abb, Aab). 3D reconstruction of the profile scan (Fig.14 f; Fig. $15 \mathrm{~h}$ ) revealed the distribution of FRET between CFP-drebrin and Cx43-YFP underneath the plasma membrane.

FRET proximity between CFP-drebrin and connexin43-YFP was further confirmed in independent experiments using a Zeiss LSM510 META microscope setup (Fig.16). CFPdrebrin and Cx43-YFP interactions were analysed in live cells during the time-dependent photoinactivation of the acceptor in the region of cell-cell contacts were both donor and acceptor were present (Fig.16 a). The time-dependent increase in the donor fluorescence (CFP-drebrin) was inversely proportional to the degree of acceptor (Cx43-YFP) inactivation (Fig.16 b). All images are representative of at least 3 independent sets of experiments and confirm that the interaction between drebrin and connexin 43 occurs in a live cell in the region of cell-cell contact. 

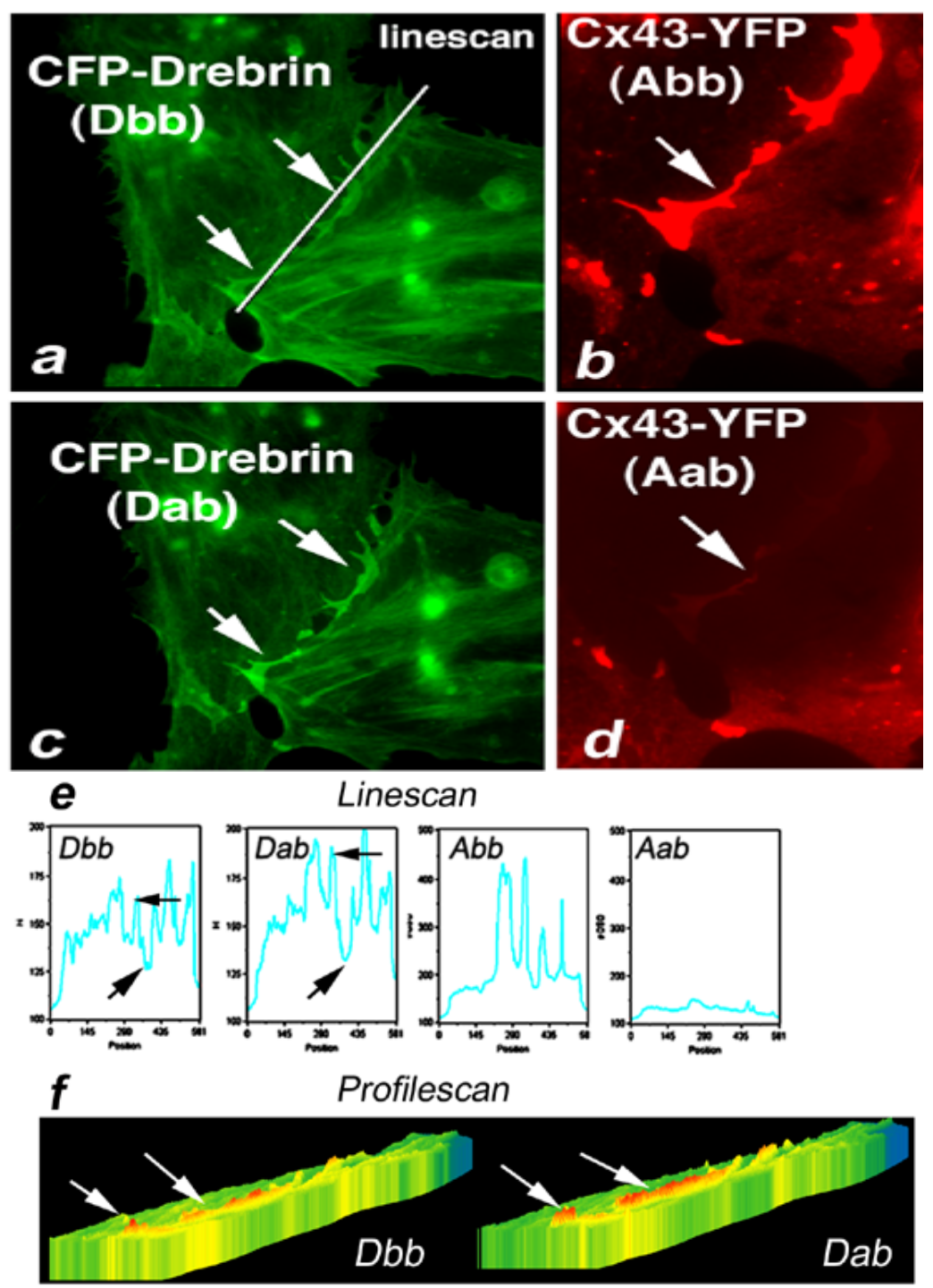

Fig. 14 FRET analyses of live Vero cells, expressing CFP-drebrin (donor)/connexin43YFP (acceptor).

$\mathrm{a}-\mathrm{b})$ : Donor (Dbb) and acceptor (Abb) images before acceptor bleaching.

$\mathrm{c}-\mathrm{d}$ ): Donor (Dab) and acceptor (Aab) images after acceptor bleaching by laser irradiation at $\lambda_{\mathrm{ex}}=530 \mathrm{~nm}$.

e): corresponding linescans (Dbb, Dab, Abb, Aab) along cell-cell interface: small arrows indicate increase in donor fluorescence, big arrows show unchanged background. f): $3 \mathrm{D}$ reconstruction of profile scan shows the distribution of FRET between CFPdrebrin and Cx43-YFP under the plasma membrane (arrows indicate increase in donor fluorescence of Dab compared to Dbb). 


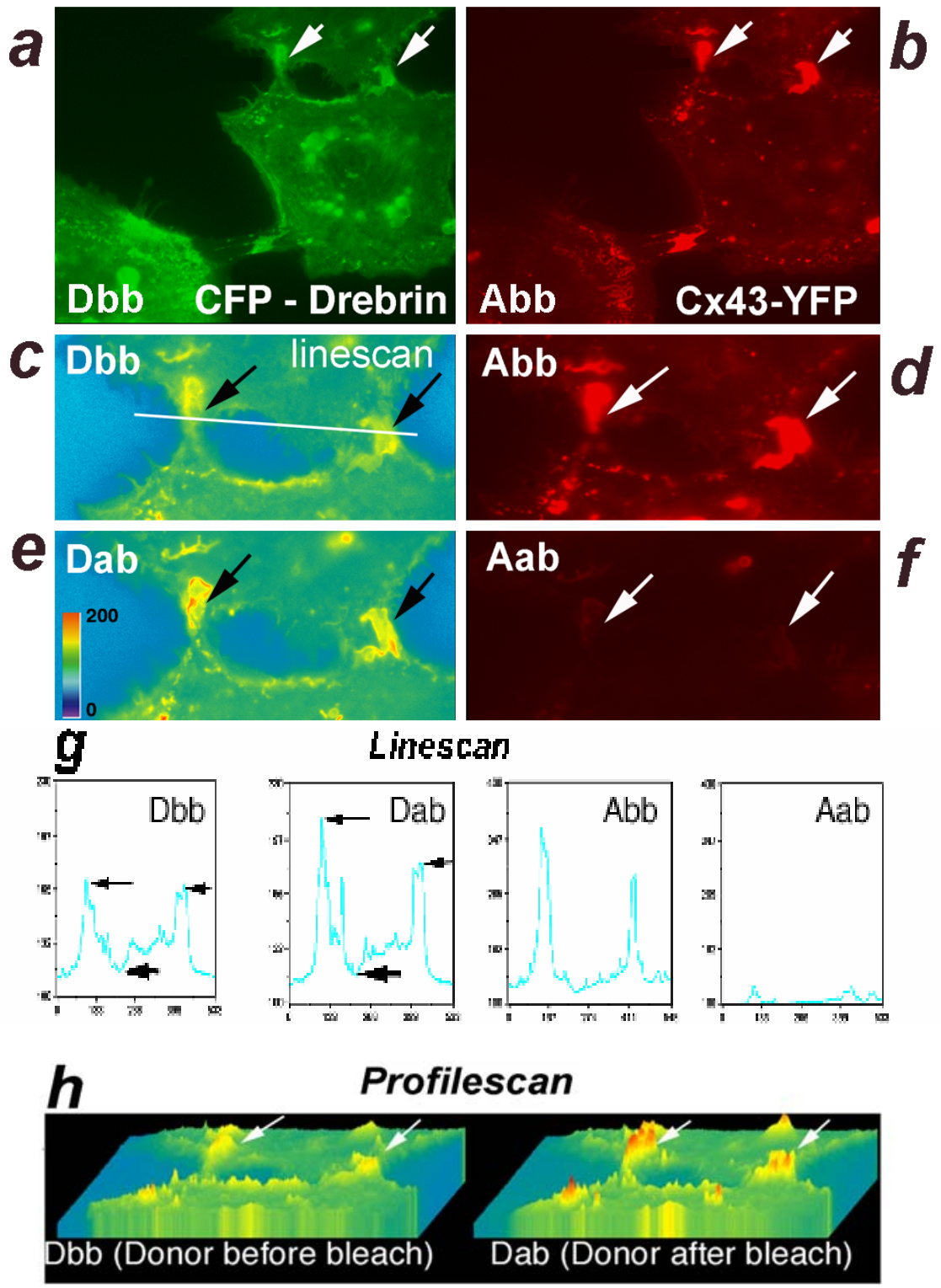

Fig.15 FRET analyses of live Vero cells, expressing CFP-drebrin/connexin43-YFP. $\mathrm{a}-\mathrm{b}$ ):CFP-drebrin (donor) and $\mathrm{Cx} 43-\mathrm{YFP}($ acceptor), expressed in Vero cells, colocalise at cell-cell contact (arrows).

$\mathrm{c}-\mathrm{d}$ ): Donor (Dbb) and acceptor (Abb) images before acceptor bleaching e - f): Donor (Dab) and acceptor (Aab) images after acceptor bleaching by laser irradiation at $\lambda_{\text {ex }} 530 \mathrm{~nm}$.

$\mathrm{g})$ : corresponding linescans (Dbb, Dab, Abb, Aab) along cell-cell interface: small arrows indicate increase in donor fluorescence, big arrows show unchanged background. h): $3 \mathrm{D}$ reconstruction of profile scan shows the distribution of FRET between CFPdrebrin and Cx43-YFP under the plasma membrane (arrows indicate increase in donor fluorescence of Dab compared to Dbb). 

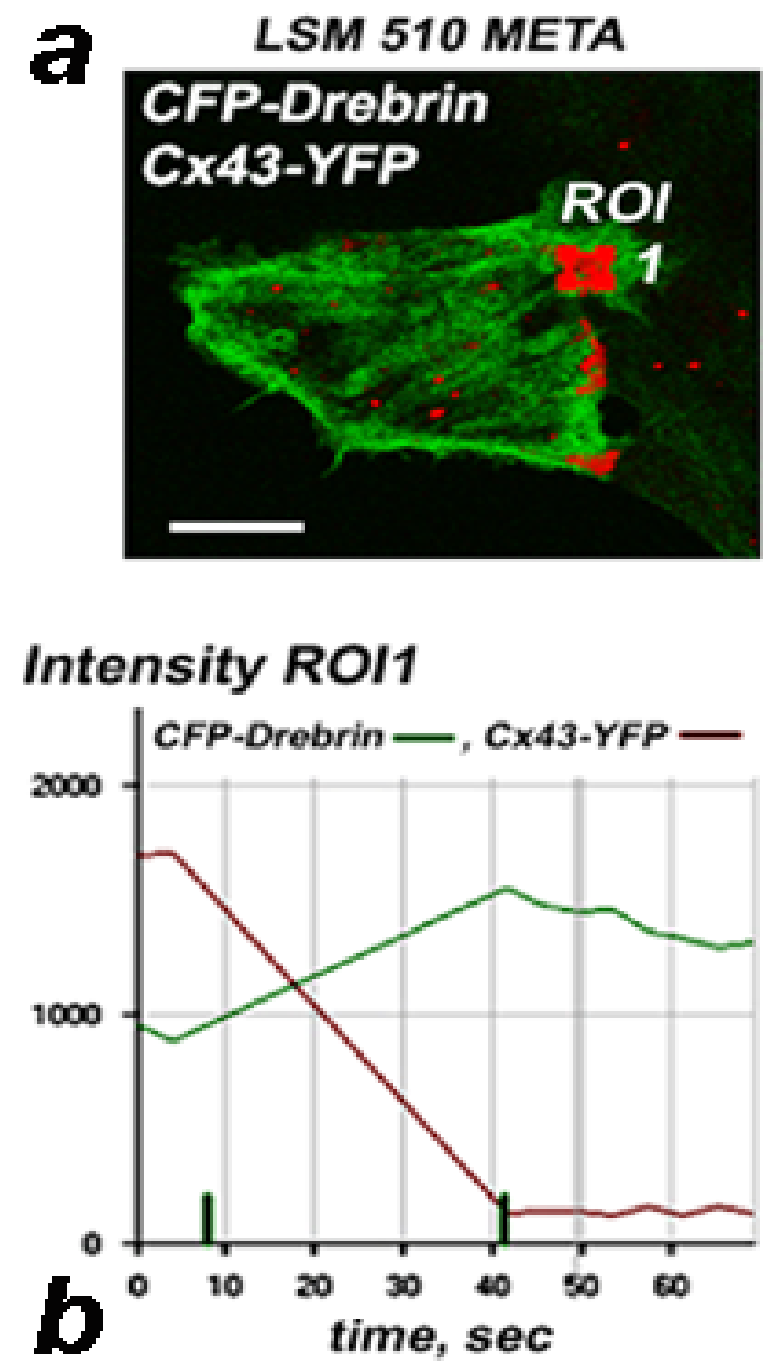

Fig.16 FRET between CFP-drebrin and Cx43-YFP detected with the LSM 510 Meta microscope.

a): Pair of Vero cells expressing CFP-drebrin (donor), shown in green and Cx43-YFP (acceptor), shown in red, before inactivation of acceptor.

Laser irradiation $\lambda_{\text {ex }} 514 \mathrm{~nm}$ was applied to bleach Cx43-YFP (acceptor) in the region of cell-cell contact ROI1

b): Registration of intensity of donor and acceptor fluorescence during bleaching of acceptor. Time-dependent increase in the donor fluorescence (CFP-drebrin) is inversely proportional to the degree of acceptor (Cx43-YFP) inactivation. 


\subsection{Analysis of connexin43-drebrin interaction by si-RNA induced drebrin depletion}

To understand the role of an interaction between drebrin and connexin 43 in a live cell the level of endogenous drebrin was reduced by transfection with si-RNA duplex oligos directed against drebrin m-RNA.

In control Vero cells drebrin and $\mathrm{Cx} 43$ were colocalized at the regions of cell-cell contacts as was detected by immunofluorescence (Fig. 19 a,b). $48 \mathrm{~h}$ after oligofectamine transfection with the si-RNA oligos against drebrin a significant decrease in both the immunoblot (Fig.17) and immunofluorescence signals with anti-drebrin antibodies (Fig.19 c) was observed.

The decrease in the endogenous drebrin level in si-RNA transfected Vero cells resulted also in a dramatic decrease of the endogenous $\mathrm{Cx} 43$ level compared to the control cells (Fig.17; Fig.19 d). Moreover, in astrocytes drebrin depletion by si-RNA correlated with loss of phosphorylated Cx43 forms (Fig.18).

A si-RNA knock-down of drebrin increased connexin43-GFP scattering through the cytoplasm (Fig.20 a) as compared to the membrane appearance in control cells. Electron microscopy analysis of these cells revealed the formation of multimembrane structures corresponding to internalised "annular junctions" (Fig.21).

Furthermore, in actin-GFP expressing cells we observed extensive ruffling of the plasma membrane after transfection with drebrin-siRNA that was not observed in control cells (Fig.22). 


\section{siDrRNA control}

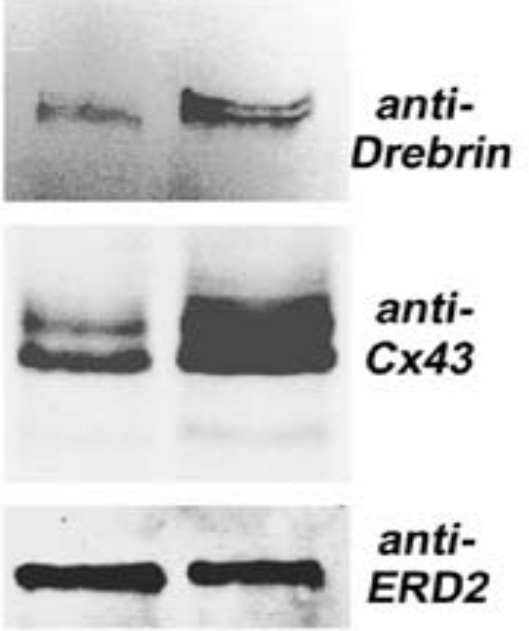

Fig.17 Immunoblot analysis of Vero cells transfected with siRNA directed against drebrin ( $24 \mathrm{~h}$ after transfection). Note that the decrease in drebrin level results in a dramatic decrease of $\mathrm{Cx} 43$ level compared to the control cells. Anti-ERD2 antibodies were used as a loading control.

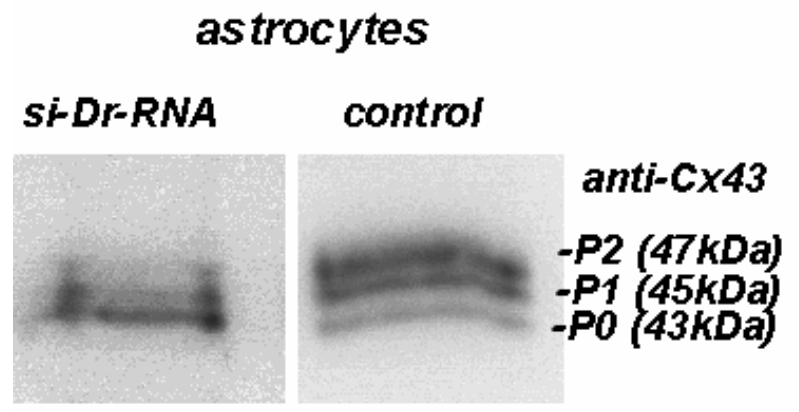

Fig.18 Western blot of astrocytes transfected with siRNA against drebrin and stained with anti-connexin43 antibodies (24h after transfection). Si-RNA-transfected astrocytes show not only a decrease of total connexin 43 but also a shift from the phosphorylated forms to the nonphosphorylated species. 


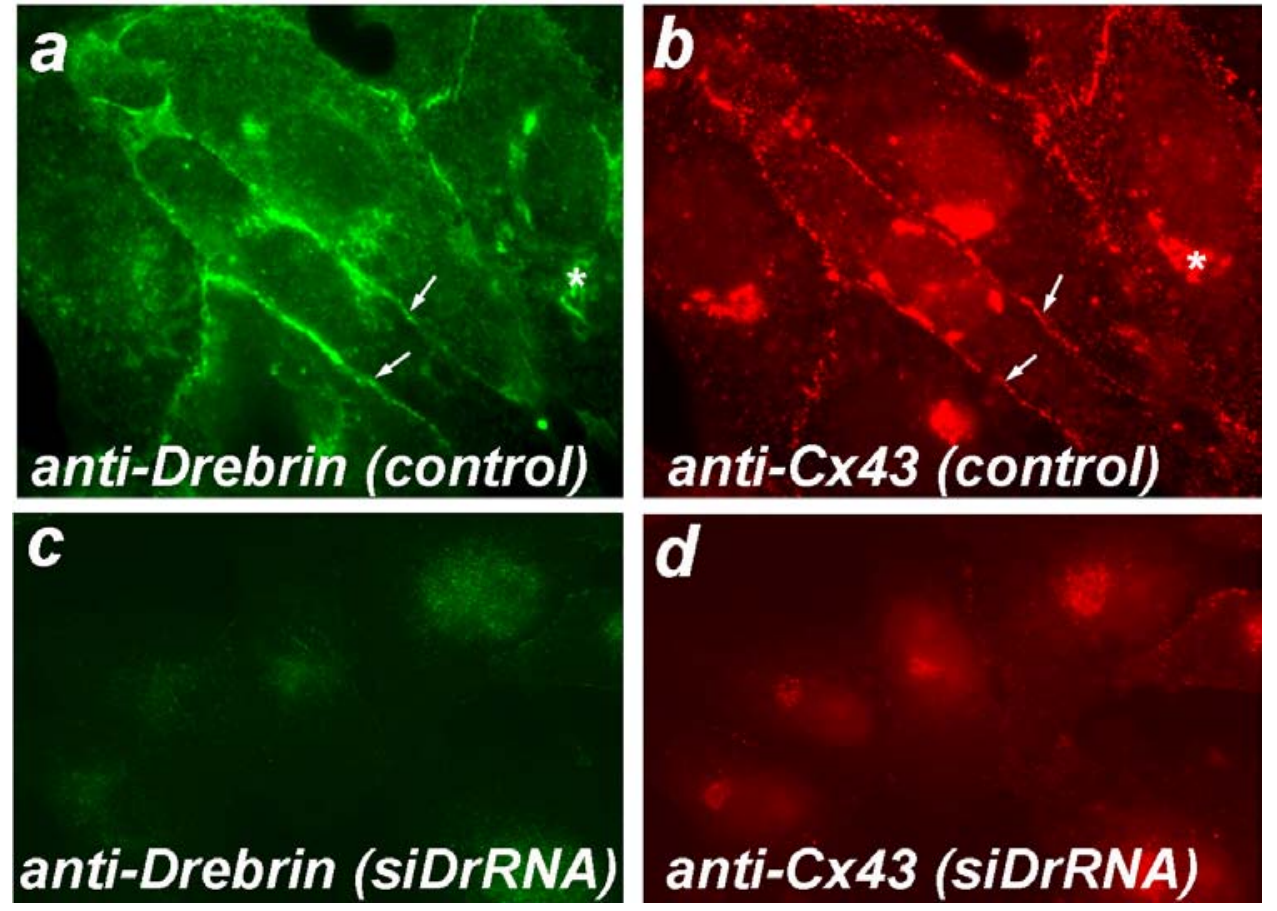

Fig.19 a-b): Distribution of endogenous drebrin and connexin43 in Vero cells revealed by immunofluorescence with anti-drebrin and anti-Cx43 antibodies. Both proteins colocalize under the plasma membrane (arrows) but do not colocalize in the Golgi region (*). $\mathrm{c}-\mathrm{d}$ ): Localization of drebrin and $\mathrm{Cx} 43$ detected $48 \mathrm{~h}$ after transfection of Vero cells with si-RNA against drebrin as detected with the same antibodies. Note that decrease in the level of drebrin correlates with a decrease of $\mathrm{Cx} 43$ immunoreactivity and disappearance of $\mathrm{Cx} 43$ from the submembrane zones of cell-cell contacts. 

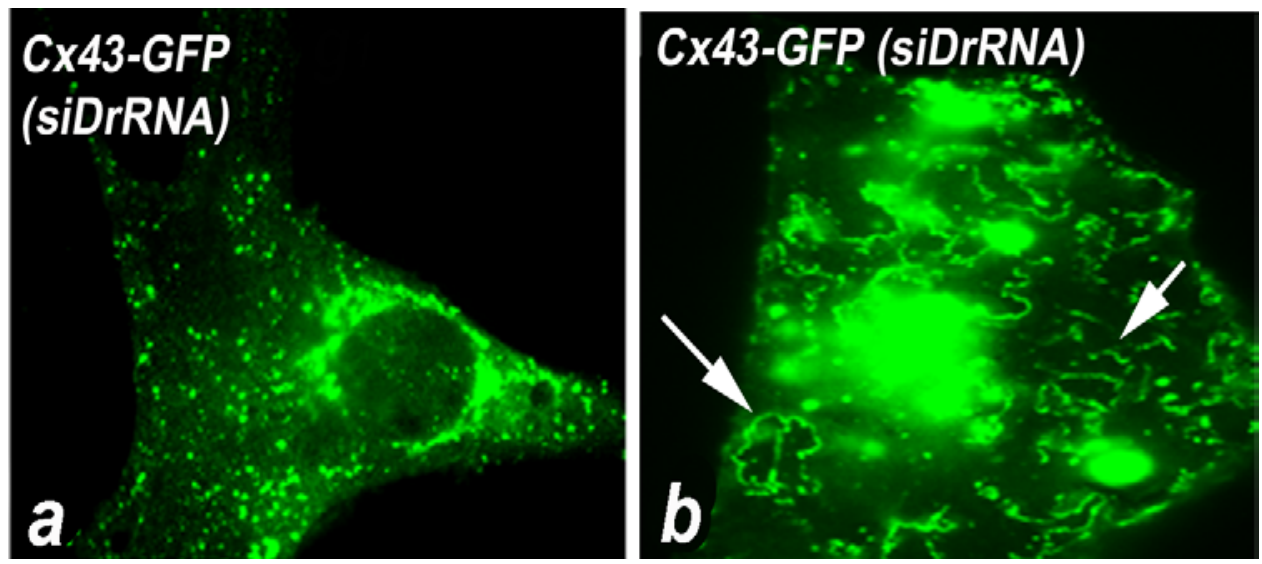

Fig.20 a): Scattering of Cx43-GFP through out the cytoplasm in Vero cells transfected first with siRNA against drebrin (24h) followed by Cx43-GFP plasmid transfection (10h). b):Vero cells co-transfected with siRNA against drebrin and a plasmid coding for $\mathrm{Cx} 43$ GFP (10h). Arrows show the ruffled lesions of the plasma membrane.

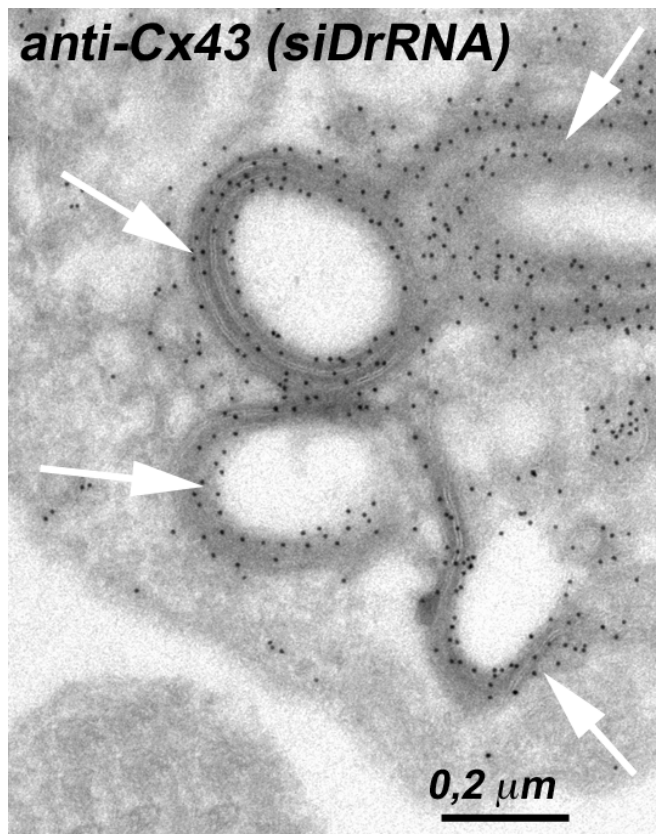

Fig.21 Immuno electron microscopy of Vero cells co-transfected with Cx43-GFP and siRNA against drebrin and stained with anti-Cx43 antibodies (10h after transfection). Arrows indicates the formation of multimembrane "annular junctions". 

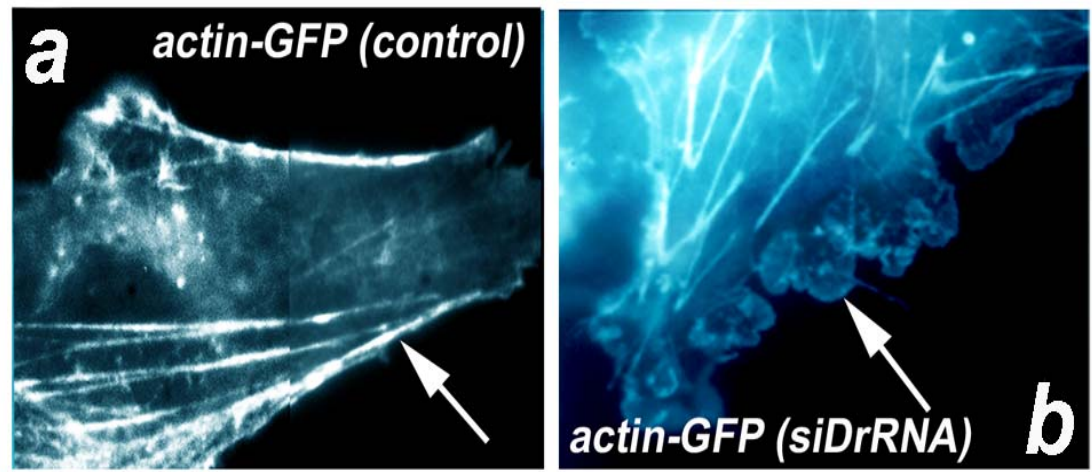

Fig.22 Vero cells transfected with a plasmid coding for GFP-actin (a) or co-transfected with si-RNA against drebrin and a plasmid coding for GFP-actin (b). Down-regulation of drebrin induces a dramatic ruffling of the plasma membrane (shown $10 \mathrm{~h}$ after transfection).

\subsection{Effect of latrunculin B on a state of drebrin}

To test whether the submembrane localization of drebrin depends on the presence of polymerized actin, we treated Vero cells with the actin- depolymerising drug, latrunculin B (100nM). In Vero cells, co-expressing connexin-YFP and CFP-drebrin, drebrin accumulated underneath the plasma membrane of contacting cells after latrunculin B treatment, i.e was not dispersed through the cytoplasm in the absence of actin filaments (Fig.23).
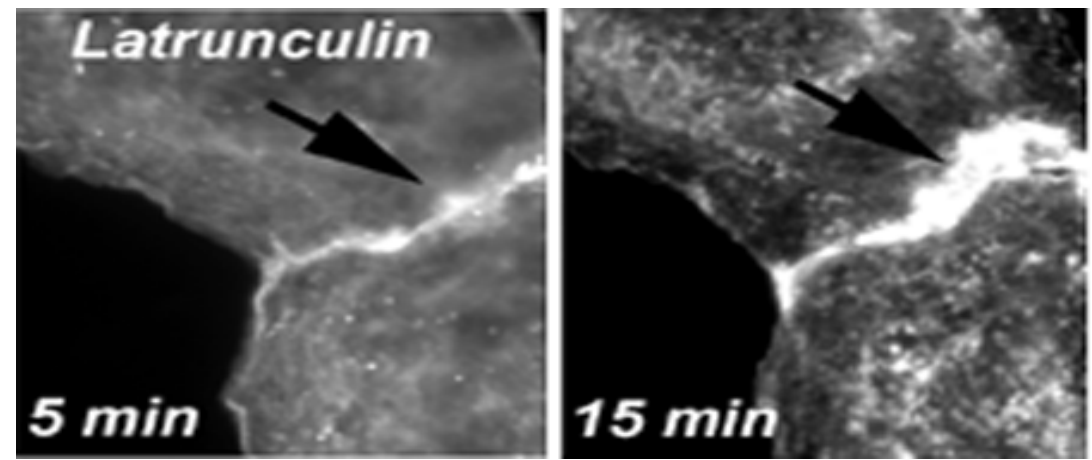

Fig.23 Time dependent accumulation of drebrin under the plasma membrane of Vero cells coexpressing CFP-drebrin and Cx43-YFP upon latrunculin B treatment. 


\subsection{Functional analyses of connexin43-drebrin interaction}

Dye transfer analysis and electrical coupling experiments were applied to analyse the functional state of gap junctions at decreased levels of drebrin following treatment with anti-drebrin si-RNA.

\subsubsection{Dye transfer analysis}

Astrocytes of confluent monolayer, non-transfected or transfected with si-RNA against drebrin were microinjected with calcein. In control cells, dye was immediately transferred from one cell to 8-20 neighbouring $(\mathrm{n}=10)$. Transfer of calcein between drebrin-deficient astrocytes was slower and was visible in only 2-3 neighbouring cells $(n=12)($ Fig.24).
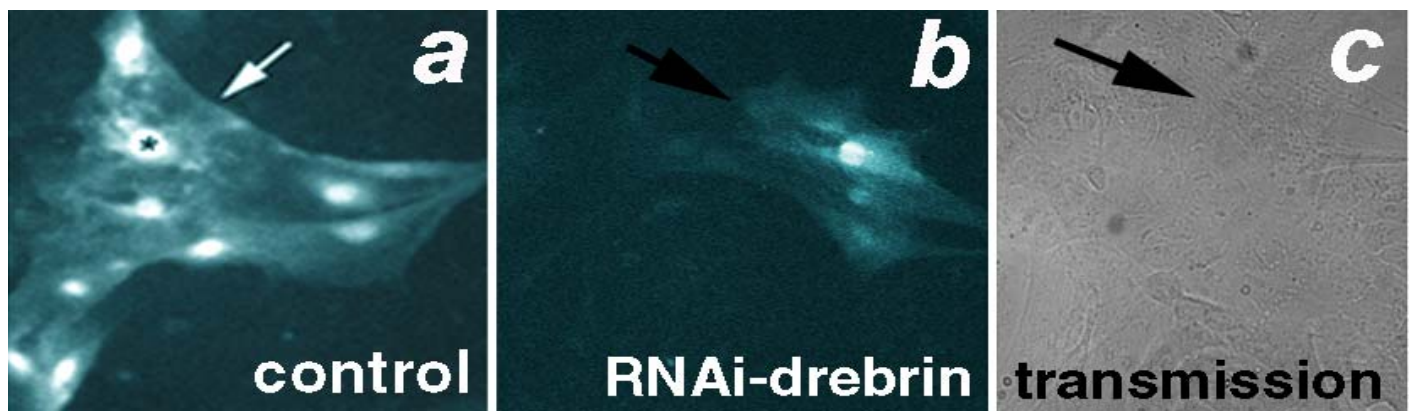

Fig.24 a): Astrocytes microinjected with calcein display within a few seconds the transfer of dye to the adjacent cells via the functional gap junctions $(*$ indicates a microinjected cell). b-c): Strong decrease of calcein transfer observed in astrocytes transfected with drebrin si-RNA ( $24 \mathrm{~h}$ after transfection), although contacting cells are clearly visible in the transmission light image.

\subsubsection{Electrical coupling experiments}

Double whole-cell voltage-clamp recording of pairs of primary cultured astrocytes was used to analyse the state of cell-cell contact permeability (Fig.25). One cell of the pair was exposed to voltage pulses of $200 \mathrm{~ms}$ with a holding potential at $-70 \mathrm{mV} / 10 \mathrm{mV}$ increment (cell1), wile the adjacent cell was kept at $-70 \mathrm{mV}$ (cell2). Current responses from both cells, the stimulated cell $\left(I_{1}\right)$ and the neighbouring cell coupled through the gap junctions $\left(I_{2}\right)$ were recorded. 
Comparison of the currents that pass through the gap junctions $\left(\mathrm{I}_{2}\right)$ of control cells, of cells co-transfected with drebrin-si-RNA and a plasmid encoding the transmembrane Golgi protein p23-CFP, or control cells transfected with just the p23-CFP plasmid revealed a strong decrease in cell-cell permeability in drebrin si-RNA transfected astrocytes (Fig.25). This effect was statistically significant indicating that si-RNAmediated depletion of drebrin strongly decreases cell-cell permeability.

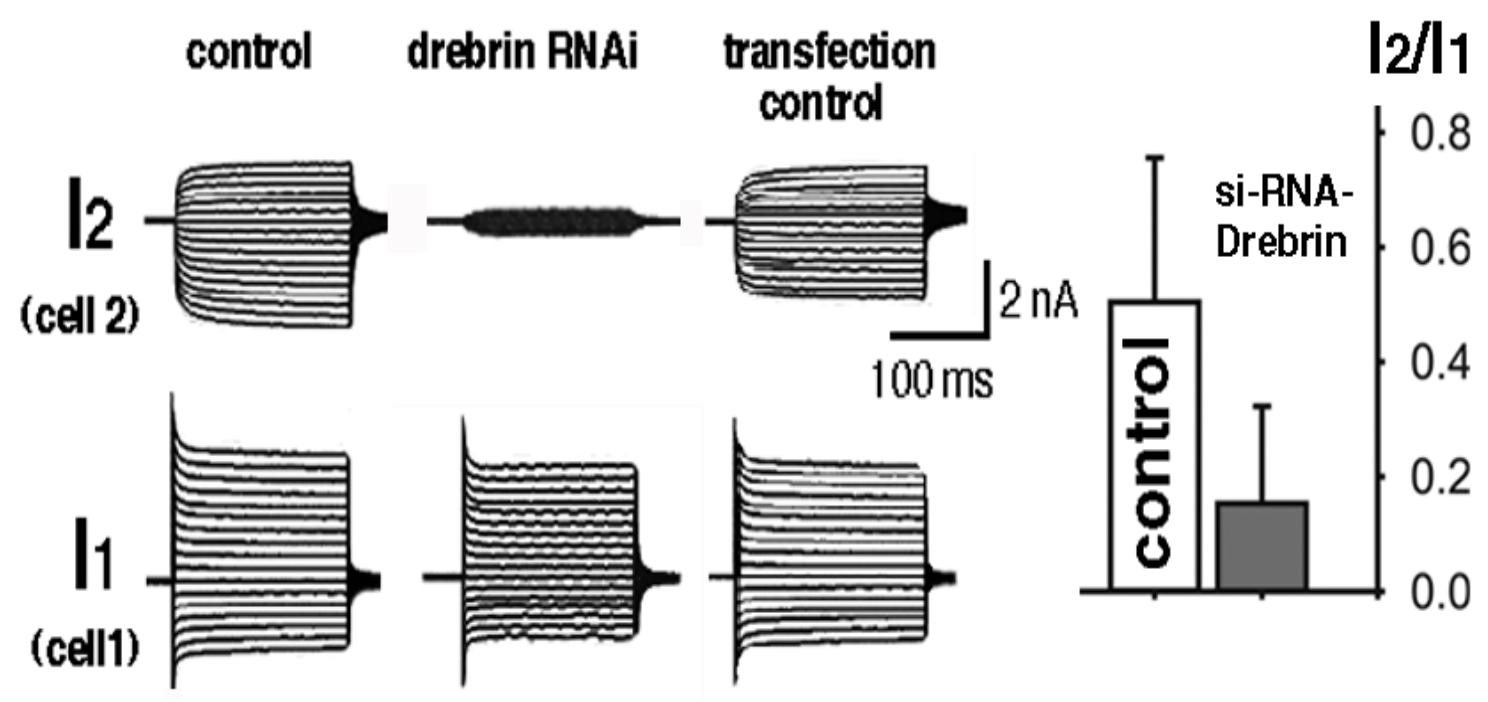

Fig.25 Double whole cell voltage clamp recordings of a pair of cultured protoplasmic astrocytes. One cell of the pair (cell 1) was exposed to voltage pulses (200ms; holding potential $-70 \mathrm{mV} ; 10 \mathrm{mV}$ increment), while adjacent cell (cell 2) was kept at $-70 \mathrm{mV}$. Currents from the stimulated cell $\left(\mathrm{I}_{1}\right)$ and currents that pass through the gap junctions $\left(\mathrm{I}_{2}\right)$ were recorded from either control cells, cells co-transfected with si-RNA against drebrin plus a control plasmid encoding the transmembrane Golgi protein p23-CFP, or cells transfected with the p23-CFP plasmid alone. Cells transfected with si-RNA against drebrin were recognized by the $\mathrm{p} 23$-CFP signal and by Cy3 label of the oligos. Three representative cells are shown together with a statistical evaluation ( $\mathrm{n}=5$ for control cells and $\mathrm{n}=6$ for cells transfected with drebrin si-RNA). Control astrocytes: coupling ratio $=\mathrm{I}_{2}$ $/ \mathrm{I}_{1}=0.52+/-0.27$; si-RNA drebrin: $\mathrm{I}_{2} / \mathrm{I}_{1}=0.14+/-0.03(\mathrm{n}=5), \mathrm{P}<0.004$. 


\section{Discussion}

Connexins form gap junctions that mediate the transfer of ions, metabolites and second messengers between contacting cells. Many connexin functions, e.g cellular transport, plaque assembly and stability, and channel conductivity are finally tuned and most likely involve proteins that bind to the cytoplasmic domains of connexins. However, little is known yet about such regulatory proteins.

In the present work new proteins, which are involved in the intracellular trafficking of connexin 43 and in the maintenance of the functional activity of gap junctions underneath the plasma membrane were identified.

Plasma membrane appearance of connexin 43 was found to depend on the functional activity of the small-GTPases Sar1 and ARF1. Transport of Cx43 from the ER to the Golgi apparatus was blocked by expression of a GTP-restricted mutant of Sar1. GTPbound mutant of ARF1 prevented transport of $\mathrm{Cx} 43$ from the Golgi apparatus to the plasma membrane.

Drebrin was identified by a proteomics approach as a new interacting partner for the $\mathrm{COOH}$-terminal domain of connexin43. Drebrin had previously been described as an actin-binding protein that is decreased in brains during Alzheimer's disease progression. The novel drebrin- $\mathrm{Cx} 43$ interaction described in my work was confirmed by colocalisation of endogenous proteins in astrocytes and in Vero cells, coimmunoprecipitation, electron microscopy, electrophysiology, co-expression of both proteins with fluorescent tags and by live cell FRET analysis. Depletion of drebrin in cells with si-RNA resulted in impaired dye and electrical coupling, internalisation of gap junctions, and targeting of $\mathrm{Cx} 43$ to a degradative pathway.

\subsection{Involvement of small GTPases in the intracellular trafficking of connexin 43}

Intracellular trafficking of connexins is an area of intense interest, since mutations in plasma membrane proteins, that inhibit their transport to the cell surface, can cause diseases (Kim and Arvan, 1998; Aridor and Balch, 1999). Such diseases result from the absence of the wild-type protein and proteins associated with it, from the plasma 
membrane. In some cases undegraded proteins accumulate in the ER and induce chronic endoplasmic reticulum stress response, which in turn can lead to major changes in cell physiology such as in the case of a mutant of connexin32, which causes Charcot-MarieTooth peripheral neuropathy (Deschenes et al., 1997).

Connexin43, as many other plasma membrane proteins, pass from the ER through the Golgi apparatus to the plasma membrane. Nevertheless, the details of intracellular trafficking of connexin 43 from the ER as well as data about the involvement of the COPII and COPI-dependent machineries in this process are unknown.

The small GTPase Sar1 is involved in the COPII-dependent budding of transport vesicles from the ER membrane (Yoshihisa et al., 1993; Kuge et al., 1994; Aridor et al., 1995, 2001). The exchange of GDP for GTP activates Sar1, causes it to bind to the ER membrane and induce the recruitment of coat proteins to form coated buds and subsequently coated vesicles. Expression of a GTP-restricted mutant Sar1 in Vero cells blocks the formation of COPII coated transport vesicles and subsequently the trafficking of $\mathrm{Cx} 43$ from the ER. Moreover, connexin43 accumulates in the ER release sites, colocalising with Sec13p, a protein of the COPII complex, which is considered to be a marker of ER-release sites (Salama et al., 1993; Hobman et al., 1998; Tang et al., 1997). ARF1 (ADP-ribosylation factor) is a small GTPase, which regulates the budding of COPI coated transport vesicles from the Golgi network (Pepperkok et al., 1998; Schekman and Orci, 1996; Springer et al., 1999; Sprang et al., 2002). ARF1Q71L, a GTP-restricted mutant of ARF1, which is bound to the Golgi membrane, induces accumulation of Cx43 in the Golgi complex.

These findings suggest that transport of connexin 43 to the plasma membrane is dependent on the functional activity of small GTPases Sar1 and ARF1 and thus COPII and COPI-mediated processes. Disturbance of anterograde trafficking to the plasma membrane induces accumulation of connexin 43 inside the ER or the Golgi complex. 


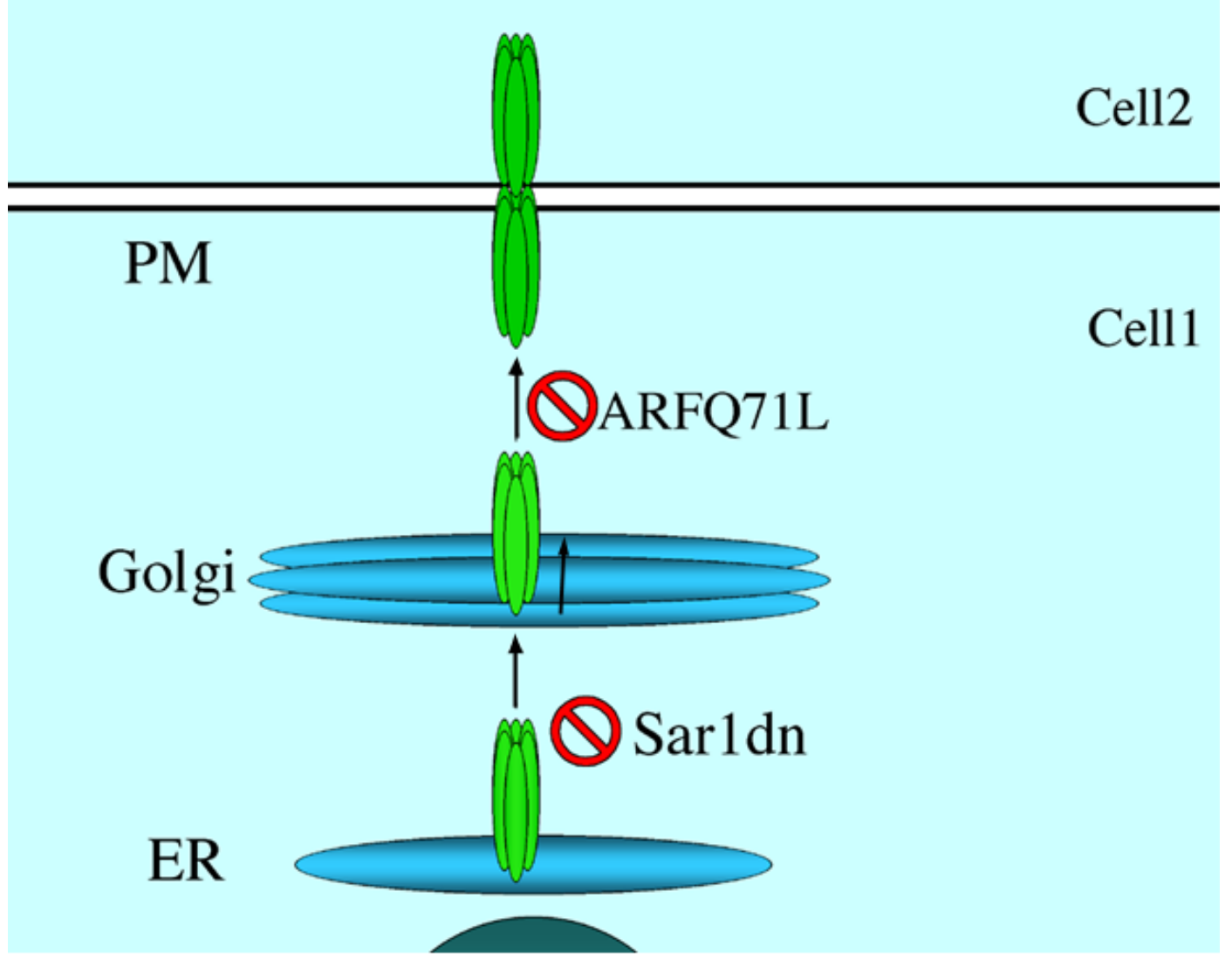

Fig.26 Transport of connexin43 to the plasma membrane can be blocked by GTPrestricted GTPases Sar1dn or ARF1Q71L. Expression of Sar1 dn blocks exit of Cx43 from the ER, ARF1Q71L induces accumulation of $\mathrm{Cx} 43$ in the Golgi.

\subsection{Identification of proteins interacting with connexin 43}

Potentially, the cytoplasmic $\mathrm{C}$-terminal domain of $\mathrm{Cx} 43$ is a highly regulated region that contains multiple sequences for interactions including modification by phosphorylation by different kinases and molecules that will recognize the phosporylated C-terminus, tubulin, ZO-1, and other molecules containing PDZ, SH2, and SH3 domains.

In search for new interaction partners of $\mathrm{Cx} 43$ a proteomics approach was used to screen subcellular fractions from different mouse tissues (brain, kidney, lung, heart, liver) for proteins that may interact with a GST-fusion protein encompassing the COOHterminal domain of $\mathrm{Cx} 43$ (residues 234-382), which is exposed to the cytosol. 
Pull-down assay using this $\mathrm{Cx} 43-\mathrm{COOH}$ terminal domain fusion protein recovered several bands that were resolved by SDS-PAGE and visualized with Coomassie Blue. MALDI/ Q-TOF (matrix assisted laser desorption ionisation/ quadripole time of flight) mass spectrometry analysis of tryptic peptides identified a number of these proteins. One of them, drebrin E, was reproducibly recovered in pull-down assays from the brain membrane fraction using the Cx43-GST fusion protein. 22 matching peptides with exact matches to cDNA-derived protein sequence of drebrin were obtained by Q-TOF sequence analysis.

A $55 \mathrm{kDa}$ band was identified as $\beta$-tubulin, which had already been described as a protein interacting with $\mathrm{Cx} 43$ (Giepmans et al., 2001). Another previously described Cx43 interacting protein, the tight junction protein ZO-1 (Toyofuku et al., 1998;

Giepmans and Moolenaar, 1998), was not recovered on the Cx43-GST fusion protein under our experimental conditions, which included the presence of $1 \%$ Triton and ATP in the binding reaction and wash buffers.

\subsection{Interaction between connexin 43 and drebrin}

As an interaction between connexins and drebrin had not been described before, I put the main emphasise of my work on this aspect.

Drebrin is an F-actin- binding protein originally identified in brain as a neuronalspecific developmentally regulated brain protein (Shirao and Obata, 1985; Ishikawa et al., 1994). Drebrin exists in two isoforms: A (adult) and E (embryonic). Drebrin A is specifically located in the postsynaptic dendritic spines of neurons (Hayashi et al., 1996) and involved in their plasticity (Hayshi and Shirao, 1999). Drebrin E is a ubiquitous isoform, which localises to the submembrane region of neurons as well as non-neuronal cells such as stomach and kidney epithelia (Asada et al., 1994; Keon et al., 2000). Recently it has been shown that drebrin regulates interactions between the NR1 subunit of the NMDA glutamate receptor and $\alpha$-actinin, calmodulin and actin filaments (Shirao and Sekino, 2001).

Drebrin contains an actin-depolymerizing factor (ADF-H) domain and at least one SH3-domain of five prolin-rich domains (Lappalainenen al., 1998; Larbolette et al., 1999). SH3-domains are 50-70 amino acid long protein domains that bind to the GK 
(guanylate kinase- homologous) module or to proteins containing a PXXP sequence. It may be of importance, that the $\mathrm{COOH}$ terminus of connexin43 contains PXXP domains, which could bind to the SH3-domain of drebrin.

\subsection{Drebrin - connexin 43 interaction occurs under the plasma membrane of contacting cells}

Immunostaining with corresponding antibodies revealed that in astrocytes and in Vero cells drebrin and connexin43 clearly co-localise underneath the plasma membrane in the region of cell-cell contacts. In contrast, around the Golgi region both proteins are also present but clearly segregated from each other. Co-expression of CFP-drebrin and Cx43YFP constructs in live COS cells revealed that drebrin is strongly accumulated in contacting regions of the plasma membrane only if $\mathrm{Cx} 43$ is present there. FRET analysis (acceptor bleach) revealed significant increase of the donor (CFP-drebrin) fluorescence after bleaching of the acceptor (Cx43-YFP) indicating the close proximity of CFP-drebrin and connexin43-YFP under the plasma membrane of contacting cells. In vitro drebrin can be co-immunoprecipitated with connexin43 from the plasma membrane fraction, but not from a Golgi membrane fraction.

Taken together, this indicates that the interaction of connexin 43 and drebrin is specific for the plasma membrane and does not occur around the Golgi region.

\subsection{Drebrin may facilitate formation of gap junctions by alignment of the plasma membranes of contacting cells}

CFP-drebrin and GFP-actin expressed in Vero cells are co-localised both at the plasma membrane and at stress fibres. An interesting finding was made in experiments following depletion of drebrin. Transfection of cells with si-RNA directed against drebrin affected only actin, localised at the plasma membrane, but not actin stress fibres, and induced dramatic ruffling of the plasma membrane, which was not observed in control cells.

These findings suggest that drebrin-actin interaction under the plasma membrane is important to preserve the cell shape and that alignment of the contacting plasma membranes is a necessary condition for gap junction formation. 


\subsection{Interaction between drebrin and connexin at gap junctions is stronger than interaction between drebrin and actin}

Treatment of Vero cells with the actin-depolymerising drug latrunculin B resulted in accumulation of drebrin underneath the plasma membrane of contacting cells and thus drebrin was not dispersed through the cytoplasm in the absence of actin filaments.

These data indicate that the interaction between drebrin and connexin 43 under the plasma membrane is much stronger that between drebrin and actin and are in agreement with data from Ikeda and colleagues (1996) and Peitsch and colleagues (1999), who showed that drebrin-positive plaques, localised at cell-cell contacts, are resistant to cytochalasin D.

\subsection{Drebrin is required for the functional activity of gap junctions between contacting cells}

It was shown previously that depolymerisation of F-actin by cytochalasins as well as microinjection of anti-actin antibodies lead to the reduction of dye transfer, electrical coupling and propagation of calcium waves via gap junctions (Branes et al., 2002, Theiss and Meller, 2002; Cotrina et al., 1998).

Here, the role of drebrin in the maintenance of the functional activity of gap junctions was analyzed. Depletion of drebrin level by si-RNA transfection resulted in $80 \%$ decrease of dye transfer between adjacent cells. Protoplasmic astrocytes, which are normally strongly electrical coupled, showed a dramatic decrease (64 \%) of the coupling ratio after drebrin knock-down. These data prove the importance of the drebrinconnexin 43 interaction for the maintenance of functional activity of gap junctions.

\subsection{Drebrin keeps the phosphorylated forms of connexin 43 at the plasma membrane}

Connexin 43 is a protein that known to be phosphorylated on both serine and tyrosine residues, which changes its mobility upon SDS-PAGE (Lin et al., 2001; Ten Broek et al., 2001; Faucheux et al., 2004). Normally, in immunoblots of cultured mouse astrocytes the 
anti-Cx43 antibodies show predominantly the upper, phosphorylated bands of $\mathrm{Cx} 43$. Recently, Faucheux and co-workers (2004) using inhibitors of cAMP-dependent protein kinase and protein kinase $\mathrm{C}$ showed a correlation between disappearance of $\mathrm{Cx} 43$ phosphorylated bands and a strong decrease in gap junction permeability. Similarly, in my experiments, siRNA-mediated drebrin depletion in astrocytes induced a reduction of the phosphorylated P1 and P2 bands of $\mathrm{Cx} 43$ together with a reduction of dye- and electrical coupling. Therefore it is tempting to speculate that drebrin in astrocytes (most likely together with other submembrane proteins) may favor the functional stabilization of $\mathrm{Cx} 43$ at the plasma membrane.

\subsection{Stabilization of gap junctions under the plasma membrane by drebrin prevents its degradation}

My experiments indicate that the abolishment of the interaction between connexin 43 and drebrin under the plasma membrane is responsible for the removal of gap junctions from the plasma membrane and targeting of $\mathrm{Cx} 43$ to a degradative pathway. The decrease in the endogenous drebrin level induced by transfection of cells with siRNA against drebrin resulted in a dramatic decrease of the endogenous $\mathrm{Cx} 43$ level. Transfection with drebrin-si-RNA induced the scattering of Cx43-GFP through out the cytoplasm and in a perinuclear Golgi region and prevented appearance of Cx43-GFP in regions of cell-cell interface. Immuno-electron microscopy of these cells revealed a large amount of "annular junctions", which represent internalised gap junctions.

\subsection{Drebrin may serve to convey signals from the connexin 43 to intracellular effectors}

In the present work it has been demonstrated that drebrin interacts with the $\mathrm{COOH}$ terminal domain of $\mathrm{Cx} 43$ and is required to maintain functional gap junctions in Vero cells and in astrocytes.

Initially, drebrin was described as an actin binding protein (Asada et al., 1994; Ishikawa et al., 1994). Drebrin thus may functions as a linker between gap junctions and the actin sub-membrane cytoskeleton. Indeed, a scaffolding role of drebrin in the 
submembrane cytoskeleton of dendritic spines has already been documented (Shirao and Sekino, 2001).

Precedents for the regulation and stabilisation of cell-cell contacts via crucial interactions with cytoplasmic proteins are well known (Jamora and Fuchs, 2002). In the classical adherence junctions, E-cadherin conveys signals to intracellular effectors using $\alpha$ - and $\beta$ - catenins to modify the submembrane cytoskeleton in response to extracellular stimuli. Similarly, drebrin may act as adapter protein that links connexin43 / gap junction signalling to the submembrane cytoskeleton.

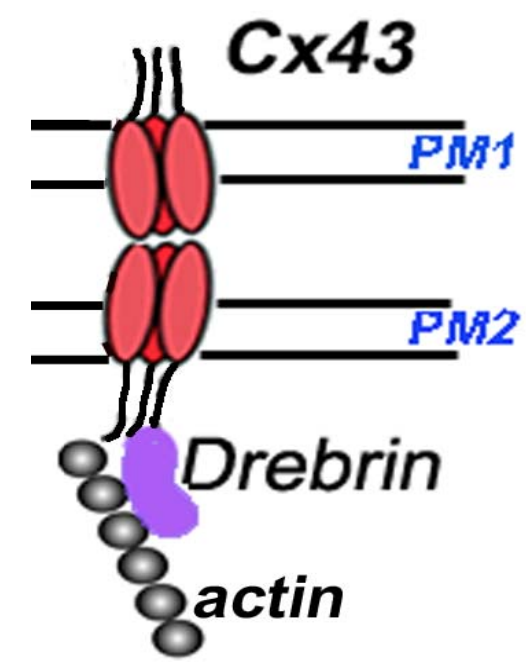

Fig. 27 Proposed model for $\mathrm{Cx} 43 /$ drebrin/actin interactions. Drebrin can act as an adaptor protein that links connexin43/gap junction signalling to components of the actin cytoskeleton.

\subsection{Connexin dysfunction may be responsible for the memory loss in Alzheimer's disease}

Alzheimer's disease (AD) is the most common cause of dementia in the elderly, which cause progressive defects in memory, cognition, attention and motivation. Pathogenesis of $\mathrm{AD}$ involves alteration in ion channels, $\mathrm{PKC}$, calcium homeostasis, amyloid processing and extensive synapse loss (Hensley et al., 1994; Chan et al., 2002; Lim et al., 2003; Stutzmann et al., 2004). 
Recent data indicates, that $\mathrm{AD}$ is associated with an $81 \%$ decrease in levels of drebrin, which regulates postsynaptic plasticity (Harigaya et al., 1996; Hatanpaa et al., 1999; Shim and Lubec, 2002).

My experiments with siRNA depletion of drebrin may mimic the decreased level of drebrin in $\mathrm{AD}$ that will cause an increased degradation of gap junctions and as a consequence impairment of electrical transmission.

To test the hypothesis of drebrin/connexin involvement in AD more experiments need to be designed and performed in whole animal experiments. 


\section{Conclusions}

In the present work I showed for the first time that transport of connexin 43 from the ER to the plasma membrane is dependent on the activity of small GTPases Sar1 and ARF1 and thus COPII and COPI-mediated processes.

Drebrin, an actin-binding protein, has been identified by proteomcs approach as a new interacting partner for $\mathrm{COOH}$-terminal domain of $\mathrm{Cx} 43$. The novel connexin43-drebrin interaction was confirmed by colocalization of endogenous proteins in astrocytes and in Vero cells, co-immunoprecipitation, electrophysiology, co-expression of both proteins with fluorescent tags and by live cell FRET analysis. Depletion of drebrin in cells with siRNA resulted in internalization of gap junctions and impaired cell-cell coupling.

On the basis of these data I conclude that drebrin is required to maintain $\mathrm{Cx} 43$ containing gap junctions in their functional state at the plasma membrane. It is thus possible that drebrin may interact with gap junctions in zones of cell-cell contacts in a regulated fashion in response to extracellular signals. The rearrangement or disruption of interaction between connexin43 and the drebrin-containing submembrane cytoskeleton directs connexin43 to degradative cellular pathways. 


\section{References:}

Aberle H, Schwartz H, Kemler R. (1996)

Cadherin-catenin complex: protein interactions and their implications for cadherin

function.

J Cell Biochem. 61, 514-23.

Allbritton NL, Meyer T, Stryer L. (1992)

Range of messenger action of calcium ion and inositol 1,4,5-trisphosphate.

Science. 258:1812-5.

Aridor M, Balch WE. (1999)

Integration of endoplasmic reticulum signaling in health and disease.

Nat Med. 5, 745-51.

Asada H, Uyemura K, Shirao T. (1994)

Actin-binding protein, drebrin, accumulates in submembranous regions in parallel with neuronal differentiation.

J Neurosci Res. 38, 149-59.

Berridge MJ, Irvine RF. (1989)

Inositol phosphates and cell signalling.

Nature. 341, 197-205.

Berridge MJ. (1997)

Elementary and global aspects of calcium signalling.

J Physiol. 499, 291-306.

Beyer EC, Paul DL, Goodenough DA. (1990)

Connexin family of gap junction proteins.

J Membr Biol. 116, 187-94.

Beyer EC, Gemel J, Martinez A, Berthoud VM, Valiunas V, Moreno AP, Brink PR. (2001)

Heteromeric mixing of connexins: compatibility of partners and functional consequences. Cell Commun Adhes. 8, 199-204.

Bjorkman N. A study of the infrastructure of the granulosa cells of the rat ovary. (1962)

Acta Anat. 51, 125-147

Boitano S, Dirksen ER, Sanderson MJ. (1992)

Intercellular propagation of calcium waves mediated by inositol trisphosphate.

Science. 258, 292-5.

Boitano S, Dirksen ER, Evans WH. (1998) 
Sequence-specific antibodies to connexins block intercellular calcium signaling through gap junctions.

Cell Calcium. 23, 1-9.

Chan SL, Furukawa K, Mattson MP. (2002)

Presenilins and APP in neuritic and synaptic plasticity: implications for the pathogenesis of Alzheimer's disease.

Neuromolecular Med. 2, 167-96.

Cheng HL, Louis CF. (2001)

Functional effects of casein kinase I-catalyzed phosphorylation on lens cell-to-cell coupling.

J Membr Biol. 181, 21-30.

Cooper CD, Lampe PD. (2002)

Casein kinase 1 regulates connexin-43 gap junction assembly.

J Biol Chem. 277, 44962-8

Cotrina ML, Lin JH, Nedergaard M. (1998)

Cytoskeletal assembly and ATP release regulate astrocytic calcium signaling.

J Neurosci. 18, 8794-804.

Crow DS, Beyer EC, Paul DL, Kobe SS, Lau AF. (1990)

Phosphorylation of connexin43 gap junction protein in uninfected and Rous sarcoma virus-transformed mammalian fibroblasts.

Mol Cell Biol. 10, 1754-63

Crow DS, Kurata WE, Lau AF. (1992)

Phosphorylation of connexin43 in cells containing mutant src oncogenes.

Oncogene. 7, 999-1003.

Darrow BJ, Fast VG, Kleber AG, Beyer EC, Saffitz JE. (1996)

Functional and structural assistsment of intercellular communication. Increased conduction velocity and enhanced connexin expression in dibutyryl cAMP-treated cultured cardiac myocytes.

Circ Res. 79, 174-83.

Denker BM, Nigam SK. (1998)

Molecular structure and assembly of the tight junction.

Am J Physiol. 274, 1-9

Deschenes SM, Walcott JL, Wexler TL, Scherer SS, Fischbeck KH. (1997)

Altered trafficking of mutant connexin 32.

J Neurosci. 17, 9077-84.

Diez JA, Elvira M, Villalobo A. (1998)

The epidermal growth factor receptor tyrosine kinase phosphorylates connexin 32. 
Mol Cell Biochem. 187, 201-10.

Filson AJ, Azarnia R, Beyer EC, Loewenstein WR, Brugge JS. (1990)

Tyrosine phosphorylation of a gap junction protein correlates with inhibition of cell-tocell communication.

Cell Growth Differ. 1, 661-8.

Giepmans BN, Moolenaar WH. (1998)

The gap junction protein connexin43 interacts with the second PDZ domain of the zona occludens-1 protein.

Curr Biol. 8, 931-4.

Giepmans BN, Verlaan I, Moolenaar WH. (2001)

Connexin-43 interactions with ZO-1 and alpha- and beta-tubulin.

Cell Commun Adhes. 8, 219-23.

Gimlich RL, Kumar NM, Gilula NB. (1990)

Differential regulation of the levels of three gap junction mRNAs in Xenopus embryos.

J Cell Biol.110, 597-605.

Ginzberg and Gilula (1979).

Modulation of cell junctions during differentiation of the chiken otocyst sensory epitelium.

Develop Biol. 110-127.

Girod A, Storrie B, Simpson JC, Johannes L, Goud B, Roberts LM, Lord JM, Nilsson T, Pepperkok R. (1999)

Evidence for a COP-I-independent transport route from the Golgi complex to the endoplasmic reticulum.

Nat Cell Biol. 1, 423-30.

Gonzalez-Mariscal L, Betanzos A, Avila-Flores A. (2000)

MAGUK proteins: structure and role in the tight junction.

Semin Cell Dev Biol.11, 315-24.

Guthrie PB, Knappenberger J, Segal M, Bennett MV, Charles AC, Kater SB. (1999)

ATP released from astrocytes mediates glial calcium waves.

J Neurosci. 19, 520-8.

Harigaya Y, Shoji M, Shirao T, Hirai S. (1996)

Disappearance of actin-binding protein, drebrin, from hippocampal synapses in

Alzheimer's disease.

J Neurosci Res. 43, 87-92.

Hatanpaa K, Isaacs KR, Shirao T, Brady DR, Rapoport SI. (1999)

Loss of proteins regulating synaptic plasticity in normal aging of the human brain and in Alzheimer disease. 
J Neuropathol Exp Neurol. 58, 637-43.

Hayashi K, Ishikawa R, Ye LH, He XL, Takata K, Kohama K, Shirao T. (1996)

Modulatory role of drebrin on the cytoskeleton within dendritic spines in the rat cerebral cortex.

J Neurosci. Nov 16, 7161-70.

Hayashi K, Shirao T. (1999)

Change in the shape of dendritic spines caused by overexpression of drebrin in cultured cortical neurons.

J Neurosci. 19, 3918-25.

Hensley K, Carney JM, Mattson MP, Aksenova M, Harris M, Wu JF, Floyd RA, Butterfield DA. (1994)

A model for beta-amyloid aggregation and neurotoxicity based on free radical generation by the peptide: relevance to Alzheimer disease.

Proc Natl Acad Sci U S A. 91, 3270-4.

Hobman TC, Zhao B, Chan H, Farquhar MG. (1998)

Immunoisolation and characterization of a subdomain of the endoplasmic reticulum that concentrates proteins involved in COPII vesicle biogenesis.

Mol Biol Cell. 9, 1265-78.

Ikeda K, Kaub PA, Asada H, Uyemura K, Toya S, Shirao T. (1996)

Stabilization of adhesion plaques by the expression of drebrin A in fibroblasts.

Brain Res Dev Brain Res. 91, 227-36.

Innocenti B, Parpura V, Haydon PG. (2000)

Imaging extracellular waves of glutamate during calcium signaling in cultured astrocytes. J Neurosci. 20, 1800-8.

Ishikawa R, Hayashi K, Shirao T, Xue Y, Takagi T, Sasaki Y, Kohama K. (1994)

Drebrin, a development-associated brain protein from rat embryo, causes the dissociation of tropomyosin from actin filaments.

J Biol Chem. 269, 29928-33.

Jongen WM, Fitzgerald DJ, Asamoto M, Piccoli C, Slaga TJ, Gros D, Takeichi M, Yamasaki H. (1991)

Regulation of connexin 43-mediated gap junctional intercellular communication by $\mathrm{Ca} 2+$ in mouse epidermal cells is controlled by E-cadherin.

J Cell Biol.114, 545-55.

Kanemitsu MY, Loo LW, Simon S, Lau AF, Eckhart W. (1997)

Tyrosine phosphorylation of connexin 43 by v-Src is mediated by SH2 and $\mathrm{SH} 3$ domain interactions.

J Biol Chem. 272, 22824-31. 
Kanemitsu MY, Jiang W, Eckhart W. (1998)

Cdc2-mediated phosphorylation of the gap junction protein, connexin43, during mitosis.

Cell Growth Differ. 9, 13-21.

Kasai H, Li YX, Miyashita Y. (1993)

Subcellular distribution of $\mathrm{Ca} 2+$ release channels underlying $\mathrm{Ca} 2+$ waves and oscillations in exocrine pancreas.

Cell. 74, 669-77.

Keon BH, Jedrzejewski PT, Paul DL, Goodenough DA. (2000)

Isoform specific expression of the neuronal F-actin binding protein, drebrin, in specialized cells of stomach and kidney epithelia.

J Cell Sci. 113, 325-36.

Kim PS, Arvan P. (1998)

Endocrinopathies in the family of endoplasmic reticulum (ER) storage diseases: disorders of protein trafficking and the role of ER molecular

chaperones.

Endocr Rev. 19, 173-202.

Kuehn MJ, Herrmann JM, Schekman R. (1998)

COPII-cargo interactions direct protein sorting into ER-derived transport vesicles.

Nature. 391, 187-90.

Kumar NM, Gilula NB. (1992)

Molecular biology and genetics of gap junction channels.

Semin Cell Biol. 3, 3-16.

Laing JG, Beyer EC. (1995)

The gap junction protein connexin43 is degraded via the ubiquitin proteasome pathway. J Biol Chem. 270, 26399-403.

Laird, D. W., Puranam, K. L. and Revel, J. P. (1991).

Turnover and phosphorylation dynamics of connexin43 gap junction protein in cultured cardiac myocytes.

Biochem. J. 273, 67 -72.

Laird, D. W., Castillo, M. and Kasprzak, L. (1995).

Gap junction turnover, intracellular trafficking, and phosphorylation of connexin43 in brefeldin A-treated rat mammary tumor cells.

J. Cell Biol. 131,1193 -1203.

Lampe, P. D. (1994).

Analyzing phorbol ester effects on gap junctional communication: a dramatic inhibition of assembly.

J. Cell Biol. 127,1895 -1905. 
Lampe PD, Kurata WE, Warn-Cramer BJ, Lau AF. (1998)

Formation of a distinct connexin43 phosphoisoform in mitotic cells is dependent upon p34cdc2 kinase.

J Cell Sci. 111, 833-41.

Lampe PD, TenBroek EM, Burt JM, Kurata WE, Johnson RG, Lau AF. (2000)

Phosphorylation of connexin 43 on serine 368 by protein kinase $\mathrm{C}$ regulates gap junctional communication.

J Cell Biol.149, 1503-12.

Lampe P.D. and Lau A.F. (2000)

Regulation of gap junctions by phosphorylation of connexins.

Arch Biochem Biophys. 384, 205-15.

Lappalainen P, Kessels MM, Cope MJ, Drubin DG. (1998)

The ADF homology (ADF-H) domain: a highly exploited actin-binding module.

Mol Biol Cell. 9, 1951-9.

Larbolette O, Wollscheid B, Schweikert J, Nielsen PJ, Wienands J. (1999)

$\mathrm{SH} 3 \mathrm{P} 7$ is a cytoskeleton adapter protein and is coupled to signal transduction from lymphocyte antigen receptors.

Mol Cell Biol. 19, 1539-46.

Larsen and Tung (1978).

Origin and fate of cytoplasmic gap junctional vesicles in rabbit granulosa cell.

Tissue Cell 10, 585-598.

Larsen, W. J., Tung, H. N., Murray, S. A. and Swenson, C. A. (1979).

Evidence for the participation of actin microfilaments and bristle coats in the internalization of gap junction membrane.

J. Cell Biol. 83,576 -587.

Lauf U, Giepmans BN, Lopez P, Braconnot S, Chen SC, Falk MM. (2002)

Dynamic trafficking and delivery of connexons to the plasma membrane and accretion to gap junctions in living cells.

Proc Natl Acad Sci U S A. 99, 10446-51.

Leybaert L, Paemeleire K, Strahonja A, Sanderson MJ. (1998)

Inositol-trisphosphate-dependent intercellular calcium signaling in and between astrocytes and endothelial cells.

Glia. 24, 398-407.

Lim AC, Qi RZ. (2003)

Cyclin-dependent kinases in neural development and degeneration.

J Alzheimers Dis. 5, 329-35.

Lin R, Warn-Cramer BJ,Kurata WE, Lau AF (2001) 
v-Src phosphorylation of connexin 43 on Tyr247 and Tyr265 disrupts gap junctional communication.

J Cell Biol. 154, 815-27.

Loo LW, Berestecky JM, Kanemitsu MY, Lau AF. (1995)

pp60src-mediated phosphorylation of connexin 43, a gap junction protein.

J Biol Chem. 270, 12751-61.

Manthey D, Bukauskas F, Lee CG, Kozak CA, Willecke K. (1999)

Molecular cloning and functional expression of the mouse gap junction gene connexin-57 in human HeLa cells.

J Biol Chem. 274, 14716-23.

Martin PE, Blundell G, Ahmad S, Errington RJ, Evans WH. (2001)

Multiple pathways in the trafficking and assembly of connexin 26, 32 and 43 into gap junction intercellular communication channels.

J Cell Sci. 114, 3845-55.

Martinez AD, Hayrapetyan V, Moreno AP, Beyer EC. (2002)

Connexin43 and connexin45 form heteromeric gap junction channels in which individual components determine permeability and regulation.

Circ Res. 90, 1100-7.

Moreno AP. (2002)

Filling more gaps: consequences of heterogeneous remodeling in connexin expression.

J Cardiovasc Electrophysiol. 13, 871-2.

Murray SA, Williams SY, Dillard CY, Narayanan SK, McCauley J. (1997)

Relationship of cytoskeletal filaments to annular gap junction expression in human adrenal cortical tumor cells in culture.

Exp Cell Res. 234, 398-404.

Musil, L. S., Cunningham, B. A., Edelman, G. M. and Goodenough, D. A. (1990). Differential phosphorylation of the gap junction protein connexin43 in junctional communication-competent and -deficient cell lines.

J. Cell Biol. 111,2077 -2088.

Musil LS, Goodenough DA. (1991)

Biochemical analysis of connexin43 intracellular transport, phosphorylation, and assembly into gap junctional plaques.

J Cell Biol. 115, 1357-74.

Musil LS, Goodenough DA. (1993)

Multisubunit assembly of an integral plasma membrane channel protein, gap junction connexin43, occurs after exit from the ER.

Cell. 74, 1065-77. 
Musil LS, Le AC, VanSlyke JK, Roberts LM. (2000)

Regulation of connexin degradation as a mechanism to increase gap junction assembly and function.

J Biol Chem. 275, 25207-15.

Niessen H, Harz H, Bedner P, Kramer K, Willecke K. (2000)

Selective permeability of different connexin channels to the second messenger inositol 1,4,5-trisphosphate.

J Cell Sci. 113, 1365-72.

Paulson AF, Lampe PD, Meyer RA, TenBroek E, Atkinson MM, Walseth TF, Johnson RG. (2000)

Cyclic AMP and LDL trigger a rapid enhancement in gap junction assembly through a stimulation of connexin trafficking.

J Cell Sci. 113, 3037-49.

Peitsch WK, Grund C, Kuhn C, Schnolzer M, Spring H, Schmelz M, Franke WW. (1999) Drebrin is a widespread actin-associating protein enriched at junctional plaques, defining a specific microfilament anchorage system in polar epithelial cells.

Eur J Cell Biol. 78, 767-78.

Pepperkok R, Lowe M, Burke B, Kreis TE. (1998)

Three distinct steps in transport of vesicular stomatitis virus glycoprotein from the ER to the cell surface in vivo with differential sensitivities to GTP gamma S.

J Cell Sci. 111, 1877-88.

Peracchia C, Wang X, Li L, Peracchia LL. (1996)

Inhibition of calmodulin expression prevents low-pH-induced gap junction uncoupling in Xenopus oocytes.

Pflugers Arch. 431, 379-87.

Peracchia C, Sotkis A, Wang XG, Peracchia LL, Persechini A. (2000)

Calmodulin directly gates gap junction channels.

J Biol Chem. 275, 26220-4.

Phelan P, Starich TA. (2001)

Innexins get into the gap.

Bioessays. 23, 388-96.

De Pina-Benabou MH, Srinivas M, Spray DC, Scemes E. (2001)

Calmodulin kinase pathway mediates the $\mathrm{K}+$-induced increase in Gap junctional communication between mouse spinal cord astrocytes.

J Neurosci. 21, 6635-43.

Plotkin LI, Bellido T. (2001)

Bisphosphonate-induced, hemichannel-mediated, anti-apoptosis through the Src/ERK pathway: a gap junction-independent action of 
connexin43.

Cell Commun Adhes. 8, 377-82.

Plotkin LI, Manolagas SC, Bellido T. (2002)

Transduction of cell survival signals by connexin-43 hemichannels.

J Biol Chem. 277, 8648-57

Postma FR, Hengeveld T, Alblas J, Giepmans BN, Zondag GC, Jalink K, Moolenaar WH. (1998)

Acute loss of cell-cell communication caused by $\mathrm{G}$ protein-coupled receptors: a critical role for c-Src.

J Cell Biol.140, 1199-209.

Qin H, Shao Q, Igdoura SA, Alaoui-Jamali MA, Laird DW. (2003)

Lysosomal and proteasomal degradation play distinct roles in the life cycle of $\mathrm{Cx} 43$ in gap junctional intercellular communication-deficient and -competent breast tumor cells.

J Biol Chem. 278, 30005-14.

Robb-Gaspers LD, Thomas AP. (1995)

Coordination of $\mathrm{Ca} 2+$ signaling by intercellular propagation of $\mathrm{Ca} 2+$ waves in the intact liver.

J Biol Chem. 270, 8102-7.

Saez JC, Nairn AC, Czernik AJ, Fishman GI, Spray DC, Hertzberg EL. (1997)

Phosphorylation of connexin43 and the regulation of neonatal rat cardiac myocyte gap junctions.

J Mol Cell Cardiol. 29, 2131-45.

Saez JC, Martinez AD, Branes MC, Gonzalez HE. (1998)

Regulation of gap junctions by protein phosphorylation.

Braz J Med Biol Res. 31, 593-600.

Salama NR, Yeung T, Schekman RW. (1993)

The Sec13p complex and reconstitution of vesicle budding from the ER with purified cytosolic proteins.

EMBO J. 12, 4073-82.

Sanderson MJ. (1995)

Intercellular calcium waves mediated by inositol trisphosphate.

Ciba Found Symp. 188, 175-94.

Schekman R, Orci L. (1996)

Coat proteins and vesicle budding.

Science. 271, 1526-33.

Shim KS, Lubec G. (2002) 
Drebrin, a dendritic spine protein, is manifold decreased in brains of patients with Alzheimer's disease and Down syndrome.

Neurosci Lett. 324, 209-12.

Shirao T, Sekino Y. (2001)

Clustering and anchoring mechanisms of molecular constituents of postsynaptic scaffolds in dendritic spines.

Neurosci Res. 40, 1-7.

Shirao T, Obata K. (1985)

Two acidic proteins associated with brain development in chick embryo.

J Neurochem. 44, 1210-6.

Shirao T, Hayashi K, Ishikawa R, Isa K, Asada H, Ikeda K, Uyemura K. (1994)

Formation of thick, curving bundles of actin by drebrin A expressed in fibroblasts.

Exp Cell Res. 215, 145-53.

Sohl G, Degen J, Teubner B, Willecke K. (1998)

The murine gap junction gene connexin36 is highly expressed in mouse retina and regulated during brain development.

FEBS Lett. 428, 27-31.

Singh D, Lampe PD. (2003)

Identification of connexin-43 interacting proteins.

Cell Commun Adhes. Jul-Dec; 10(4-6): 215-20.

Sotkis A, Wang XG, Yasumura T, Peracchia LL, Persechini A, Rash JE, Peracchia C. (2001)

Calmodulin colocalizes with connexins and plays a direct role in gap junction channel gating.

Cell Commun Adhes. 8, 277-81.

Spang A. (2002)

ARF1 regulatory factors and COPI vesicle formation.

Curr Opin Cell Biol. 14, 423-7.

Springer S, Spang A, Schekman R. (1999)

A primer on vesicle budding.

Cell. 97, 145-8.

Stevenson BR, Siliciano JD, Mooseker MS, Goodenough DA. (1986)

Identification of ZO-1: a high molecular weight polypeptide associated with the tight junction (zonula occludens) in a variety of epithelia.

J Cell Biol. 103, 755-66.

Stout CE, Costantin JL, Naus CC, Charles AC. (2002) 
Intercellular calcium signaling in astrocytes via ATP release through connexin hemichannels.

J Biol Chem. 277, 10482-8.

Stutzmann GE, Caccamo A, LaFerla FM, Parker I. (2004)

Dysregulated IP3 signaling in cortical neurons of knock-in mice expressing an Alzheimer's-linked mutation in presenilin 1 results in exaggerated $\mathrm{Ca} 2+$ signals and altered membrane excitability.

J Neurosci. 24, 508-13.

Swenson KI, Piwnica-Worms H, McNamee H, Paul DL. (1990)

Tyrosine phosphorylation of the gap junction protein connexin43 is required for the pp60v-src-induced inhibition of communication.

Cell Regul. 1, 989-1002.

Tang BL, Peter F, Krijnse-Locker J, Low SH, Griffiths G, Hong W. (1997)

The mammalian homolog of yeast Sec13p is enriched in the intermediate compartment and is essential for protein transport from the endoplasmic reticulum to Mol Cell Biol. 17, 256-66.

TenBroek EM, Lampe PD, Solan JL, Reynhout JK, Johnson RG. (2001)

Ser364 of connexin43 and the upregulation of gap junction assembly by cAMP.

J Cell Biol. 155, 1307-18.

Teubner B, Odermatt B, Guldenagel M, Sohl G, Degen J, Bukauskas F, Kronengold J, Verselis VK, Jung YT, Kozak CA, Schilling K, Willecke K. (2001)

Functional expression of the new gap junction gene connexin 47 transcribed in mouse brain and spinal cord neurons.

J Neurosci. 21, 1117-26.

Theiss C, Meller K. (2002)

Microinjected anti-actin antibodies decrease gap junctional intercellular commmunication in cultured astrocytes.

Exp Cell Res. 281, 197-204.

Thomas T, Jordan K, Laird DW. (2001)

Role of cytoskeletal elements in the recruitment of Cx43-GFP and Cx26-YFP into gap junctions.

Cell Commun Adhes. 8, 231-6.

Thomas MA, Zosso N, Scerri I, Demaurex N, Chanson M, Staub O. (2003)

A tyrosine-based sorting signal is involved in connexin43 stability and gap junction turnover.

J Cell Sci. 116, 2213-22.

Torok K, Stauffer K, Evans WH. (1997)

Connexin 32 of gap junctions contains two cytoplasmic calmodulin-binding domains. 
Biochem J. 326, 479-83.

Toyofuku T, Yabuki M, Otsu K, Kuzuya T, Hori M, Tada M. (1998)

Direct association of the gap junction protein connexin-43 with ZO-1 in cardiac

myocytes.

J Biol Chem. 273, 12725-31.

Toyofuku T, Akamatsu Y, Zhang H, Kuzuya T, Tada M, Hori M. (2001)

c-Src regulates the interaction between connexin-43 and ZO-1 in cardiac myocytes.

J Biol Chem. 276, 1780-8.

Traub O, Look J, Paul D, Willecke K. (1987)

Cyclic adenosine monophosphate stimulates biosynthesis and phosphorylation of the 26

$\mathrm{kDa}$ gap junction protein in cultured mouse

hepatocytes.

Eur J Cell Biol. 43, 48-54.

Traub O, Eckert R, Lichtenberg-Frate H, Elfgang C, Bastide B, Scheidtmann KH, Hulser DF, Willecke K. (1994)

Immunochemical and electrophysiological characterization of murine connexin40 and 43 in mouse tissues and transfected human cells.

Eur J Cell Biol. 64, 101-12.

Traub O, Look J, Dermietzel R, Brummer F, Hulser D, Willecke K. (1989)

Comparative characterization of the $21-\mathrm{kD}$ and $26-\mathrm{kD}$ gap junction proteins in murine

liver and cultured hepatocytes.

J Cell Biol. 108, 1039-51.

Wang Y, Rose B. (1995)

Clustering of $\mathrm{Cx} 43$ cell-to-cell channels into gap junction plaques: regulation by cAMP and microfilaments.

J Cell Sci. 108, 3501-8.

VanSlyke JK, Deschenes SM, Musil LS. (2000)

Intracellular transport, assembly, and degradation of wild-type and disease-linked mutant gap junction proteins.

Mol Biol Cell. 11, 1933-46.

VanSlyke JK, Musil LS. (2002)

Dislocation and degradation from the ER are regulated by cytosolic stress.

J Cell Biol. 157, 381-94.

Warn-Cramer BJ, Lampe PD, Kurata WE, Kanemitsu MY, Loo LW, Eckhart W, Lau AF. (1996)

Characterization of the mitogen-activated protein kinase phosphorylation sites on the connexin-43 gap junction protein.

J Biol Chem. 271, 3779-86. 
Wei C-J, Boja E., Fales HM, Lo CW (2003)

Interaction of the gap junction protein connexin 43 whith adherens junction assosiated proteins.

International Gap Junction Conference, abstract book, p144

White TW, Paul DL. (1999)

Genetic diseases and gene knockouts reveal diverse connexin functions.

Annu Rev Physiol. 61, 283-310.

Willecke K, Eiberger J, Degen J, Eckardt D, Romualdi A, Guldenagel M, Deutsch U, Sohl G. (2002)

Structural and functional diversity of connexin genes in the mouse and human genome. Biol Chem. 383, 725-37.

Ye ZC, Wyeth MS, Baltan-Tekkok S, Ransom BR. (2003).

Functional hemichannels in astrocytes: a novel mechanism of glutamate release.

J Neurosci. 23, 3588-96.

Yoshihisa T, Barlowe C, Schekman R. (1993)

Requirement for a GTPase-activating protein in vesicle budding from the endoplasmic reticulum.

Science. 259, 1466-8. 


\section{Acknowledgements}

I am grateful to my supervisors Dr. Swen Hülsmann and Dr. Irina Majoul for the excellent $\mathrm{PhD}$ project and their generous help and support.

The molecular biological part of this work was carried out at the Department of Neurobiology of Max Planck Institute for Biophysical Chemistry, Göttingen. I thank

Prof. Dr. Reinhard Jahn, director of this Department, who permitted me to be a part of it and who agreed to be co-referee of my thesis.

The electrophysiological experiments were done at the Centre of Physiology and Pathophysiology of the Georg-August-University, Göttingen.

I thank Prof. Dr. D.-W. Richter, the director of the Department of Neuro- and Sensory Physiology for the given possibility to work on the interesting project.

I thank Prof. Dr. F. -W. Schürmann, who agreed to be referee of my work.

I am grateful to Kathryn Lilley (Cambridge, Centre for Proteomics) and to Dr. Dirk Wenzel for their help with MALDI Q-TOF analysis used for protein identification and electron microscopy respectively.

I specially thank Dr. H.-D. Söling and Dr. Rainer Duden for their interest and constant support. 


\section{Lebenslauf}

Angaben zu Person:

Name

Vorname

Butkevich

Eugenia

Geburtsdatum:

19.09.1973

Geburtsort:

Omsk, Rußland

Staatsangehörigkeit:

weißrussich

$1980-1988$

Allgemeinbildende Schule Minsk, Weißrußland

1988-1991

Medizinische Schule, Minsk

$1992-1999$

1999

Medizinische Universität, Minsk

Diplom im Fach Medizin

$1999-2001$

Ärztin , Kinderklinikum, Minsk

1995 und 1996

Gaststudentin im Institut für Klinische

Biochemie der Georg-August-Universität

Göttingen.

November 1999 - Februar 2000

Gastwissenschaftlerin in der Abt.

Neurobiologie, Max Plank Institut für

Biophysikalische Chemie, Göttingen.

Februar 2002

Beginn der experimentellen Arbeit zur vorliegenden

Dissertation am Zentrum für Physiologie und

Pathophysiologie der Georg-August-Universität Göttingen

Mai 2004

Fertigstellung der vorliegenden Dissertation 